OPEN ACCESS

Edited by: Hans-Dieter Volk, Charité Medical University of Berlin, Germany

Reviewed by:

Guido Moll,

Charité - Universitätsmedizin Berlin, Germany Zhengzhao Liu,

Central South University, China

*Correspondence: Timothy O'Brien

timothy.obrien@nuigalway.ie

Specialty section

This article was submitted to

Translational Medicine,

a section of the journal

Frontiers in Medicine

Received: 21 June 2021

Accepted: 19 August 2021 Published: 20 September 2021

Citation:

Calcat-i-Cervera S, Sanz-Nogués C and O'Brien T (2021) When Origin Matters: Properties of Mesenchymal Stromal Cells From Different Sources for Clinical Translation in Kidney Disease. Front. Med. 8:728496. doi: 10.3389/fmed.2021.728496

\section{When Origin Matters: Properties of Mesenchymal Stromal Cells From Different Sources for Clinical Translation in Kidney Disease}

\author{
Sandra Calcat-i-Cervera, Clara Sanz-Nogués and Timothy O'Brien* \\ Regenerative Medicine Institute (REMEDI), CÚRAM, Biomedical Science Building, National University of Ireland, Galway, \\ Ireland
}

Advanced therapy medicinal products (ATMPs) offer new prospects to improve the treatment of conditions with unmet medical needs. Kidney diseases are a current major health concern with an increasing global prevalence. Chronic renal failure appears after many years of impairment, which opens a temporary window to apply novel therapeutic approaches to delay or halt disease progression. The immunomodulatory, anti-inflammatory, and pro-regenerative properties of mesenchymal stromal cells (MSCs) have sparked interest for their use in cell-based regenerative therapies. Currently, several early-phase clinical trials have been completed and many are ongoing to explore MSC safety and efficacy in a wide range of nephropathies. However, one of the current roadblocks to the clinical translation of MSC therapies relates to the lack of standardization and harmonization of MSC manufacturing protocols, which currently hinders inter-study comparability. Studies have shown that cell culture processing variables can have significant effects on MSC phenotype and functionality, and these are highly variable across laboratories. In addition, heterogeneity within MSC populations is another obstacle. Furthermore, MSCs may be isolated from several sources which adds another variable to the comparative assessment of outcomes. There is now a growing body of literature highlighting unique and distinctive properties of MSCs according to the tissue origin, and that characteristics such as donor, age, sex and underlying medical conditions may alter the therapeutic effect of MSCs. These variables must be taken into consideration when developing a cell therapy product. Having an optimal scale-up strategy for MSC manufacturing is critical for ensuring product quality while minimizing costs and time of production, as well as avoiding potential risks. Ideally, optimal scale-up strategies must be carefully considered and identified during the early stages of development, as making changes later in the bioprocess workflow will require re-optimization and validation, which may have a significant long-term impact on the cost of the therapy. This article provides a summary of important cell culture processing variables to consider in the scale-up of MSC manufacturing as well as giving a comprehensive review of tissue of origin-specific biological characteristics of MSCs and their use in current clinical trials in a range of renal pathologies.

Keywords: mesenchymal stromal cells (MSCs), tissue source, good manufacturing practice (GMP), advanced therapy medicinal products (ATMPs), kidney disease, cell therapy, clinical application 


\section{INTRODUCTION}

According to the World Health Organization 2019 Global Health Estimates, chronic diseases are one of the leading causes of mortality worldwide (1). Amongst them, chronic kidney disease accounts for $11-13 \%$ global prevalence $(2,3)$. Based on the course of the injury, kidney diseases and their spectrum of clinical manifestations are stratified into acute kidney injury (AKI), chronic kidney disease (CKD) and end-stage renal disease (ESRD) $(4,5)$. Persistent loss of kidney function over time leads to kidney failure and at that stage, the current standard of care includes renal-replacement therapies (RRT) (mainly hemodialysis and peritoneal dialysis), or organ replacement. Both strategies suffer significant drawbacks that underpin the need for new preventive and therapeutic approaches.

Cell-based regenerative therapies have the potential to change the paradigm of conventional clinical care. The use of complex biological entities such as cells to promote tissue regeneration and homeostasis, provides a therapeutic alternative to treat and even cure a wide range of diseases. The current cell-based clinical landscape in kidney disease uses hematopoietic stem cells (HSCs), mesenchymal stromal cells (MSCs), and a wide range of blood-derived cells, such as T cells, natural killer (NK) cells, and dendritic cells $(6,7)$. Notably, blood cell-based therapies using myeloid and $\mathrm{T}$ cells are gaining relevance as cellular immunotherapy products to regulate the immune response after procedures such as kidney transplantation $(8,9)$.

On the other hand, MSCs, which are considered an advanced therapy medicinal product (ATMPs) under EU regulation, have been extensively investigated during the last decade due to their ability to inhibit inflammation and initiate tissue regeneration. The immunomodulatory and anti-inflammatory effects, via interactions with immune cells, together with paracrine secretions of anti-apoptotic, anti-fibrotic and matrix remodeling factors, are the main MSC-mediated mechanisms contributing to kidney protection and regeneration (10-12) (Figure 1). The effectiveness of MSCs in the treatment of a variety of nephropathies has been largely investigated in pre-clinical models, showing promising results (13). This has encouraged the translation of their use in clinical settings and currently, several early-phase clinical trials have been completed, and many are ongoing, to explore MSC safety and efficacy in renal transplantation, autoimmune diseases, and organ regeneration, especially in late-stage chronic kidney disease patients (Table 1). Nevertheless, the road to their routine use in the clinic is far from being a reality. Results in the clinical arena have highlighted the need for better defined therapeutic products. The intrinsic heterogeneity of MSCs in addition to efficacy and safety needs to be extensively investigated before they become a sustainable and affordable therapy (4345).

One of the current roadblocks relates to a lack of standardization of manufacturing protocols across laboratories and manufacturing centers, which hinders inter-study comparisons within the field (46) and may have significant effects on cell phenotype and performance (47-49). Heterogeneity within MSC populations is another major obstacle; there is now a growing body of literature highlighting unique and intrinsic properties according to tissue origin and donor-related features, with characteristics such as sex, age and disease status having shown to affect their properties (50-54). In this regard, although clinical data has provided evidence for the safety of MSCs (55), attention has also been given to the immune compatibility and hemocompatibility of specific MSC infusions, urging the inclusion of HLA mismatch assessment and expression of procoagulant factors within the safety release criteria $(44,46,56)$.

MSCs were initially discovered by Friedenestein et al. as a non-hematopoietic population of cells within the bone marrow (BM), that were plastic-adherent, had fibroblastic phenotype, were able to generate colonies in vitro and undergo osteogenic differentiation $(57,58)$. Later, several groups identified their ability to differentiate into other mesodermal lineages such as adipocytes and chondrocytes, and their ability to be sub-passaged and expanded in vitro $(59,60)$. Since then, MSCs have undergone an extensive diversification and cells with similar characteristics have been isolated from nearly every vascularized tissue (61) as a subgroup of pericytes that reside near vessels, contributing to their homeostasis and regenerative processes (62-64). As a summary, MSCs have been obtained from adult tissues such as adipose tissue (AT-MSCs) (65), dental pulp (DP-MSCs) (66) and other dental tissues (67), endometrium (EM-MSCs) (68, 69), menstrual blood (Men-MSCs) (70), peripheral blood (PBMSCs) $(71,72)$ and from several perinatal and birth-associated tissues, referred hereafter as perinatal tissue-MSCs (PT-MSCs) including MSCs from amnion membrane (AM-MSCs), amniotic fluid (AF-MSCs), umbilical cord blood (CB-MSCs), placenta (PL-MSCs), umbilical cord tissue (UC-MSCs) and Wharton's jelly (WJ-MSCs) (73-78) (Figure 2). It is important to note that placental tissue can be fetal or maternal in origin, and therefore, MSCs derived from the two types of tissue should be individually characterized.

Current studies focus on trying to understand the mechanistic characteristics underlying MSC-like cells and their therapeutic effects with respect to the tissue of origin. To date, little is known about tissue-specific properties being able to predict clinical efficacy. Considering the significant effect that origin may have on functional properties, and possible therapeutic outcomes, it has now been recognized that the choice of cell source should be considered when optimizing manufacturing protocols for particular clinical applications. In addition to this attention to the source of MSCs, efforts should focus on developing more homogeneous manufacturing approaches to reduce inter-study variability and improve the interpretation and comparability of results from different centers, which ultimately will help to advance the field. Nevertheless, it seems plausible that an ultimate consensus or harmonization will not be reached due to reasons such as intellectual property as well as infrastructure and resources available for large-scale production.

In this article we provide a comprehensive review on the origin-specific biological characteristics of MSCs and their use in current clinical trials in a range of renal pathologies, and attempt to identify intrinsic biological characteristics with beneficial effects. We have also reviewed the literature regarding culture 
TABLE 1 | Summary of clinical trials in KD using MSC registered at ClinicalTrials. Gov. Search done on 23rd April 2021

\begin{tabular}{|c|c|c|c|c|c|c|c|c|c|}
\hline NCT number & Status & Phases & $\begin{array}{l}\text { Start } \\
\text { date }\end{array}$ & Cell source & Donor source & Dose frequency $(\mathrm{N})$ & $\begin{array}{l}\text { Infusion } \\
\text { route }\end{array}$ & Results & References \\
\hline \multicolumn{10}{|c|}{ Acute Kidney Injury } \\
\hline NCT00733876 & Completed & Phase 1 & 2008 & BM-MSC & Allogeneic & $\begin{array}{l}2 \times 10^{6} \text { cells } / \mathrm{kg} \text { body mass } \\
N=1\end{array}$ & la & $\begin{array}{l}\text { No AE or SAE } \\
\downarrow 40 \% \text { hospitalization stay and } \\
\text { readmission } \\
\text { CKD was stable up to } 16 \text { mo } \\
\text { follow-up } \\
\text { No hemodialysis required }\end{array}$ & $(14-17)$ \\
\hline NCT01602328 & Completed & Phase 2 & 2012 & BM-MSC ${ }^{a}$ & Allogeneic & $\begin{array}{l}2 \times 10^{6} \text { cells } / \mathrm{kg} \text { body mass } \\
N=1\end{array}$ & IV & $\begin{array}{l}\text { Recovery, need for dialysis, } \\
\text { 30-day mortality, AE and SAE } \\
\text { between treated and control } \\
\text { groups }\end{array}$ & (18) \\
\hline NCT01275612 & Withdrawn & Phase 1 & 2010 & BM-MSC & Autologous & $\begin{array}{l}1 \times 10^{\wedge} 6 \text { cells } / \mathrm{kg} \\
N=1\end{array}$ & IV & $\begin{array}{l}\text { Patients evaluated not meet the } \\
\text { primary criterion }\end{array}$ & (19) \\
\hline NCT04194671 & $\begin{array}{l}\text { Not yet } \\
\text { recruiting }\end{array}$ & $\begin{array}{l}\text { Phase } \\
\text { 1|Phase } 2\end{array}$ & 2020 & UC-MSC & Allogeneic & $\begin{array}{l}N A \\
N=2,7 \mathrm{~d} \text { apart }\end{array}$ & IV & & \\
\hline NCT03015623 & $\begin{array}{l}\text { Active, not } \\
\text { recruiting }\end{array}$ & $\begin{array}{l}\text { Phase } \\
\text { 1|Phase } 2\end{array}$ & 2017 & 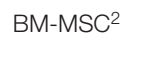 & Allogeneic & $\begin{array}{l}\mathrm{SBI}-101+2.5 \times 10^{8} \text { vs. } 7.5 \\
\times 10^{8}\end{array}$ & $\begin{array}{l}\text { Time of } \\
\text { hemodialysis }\end{array}$ & & \\
\hline NCT04445220 & Recruiting & $\begin{array}{l}\text { Phase } \\
\text { 1|Phase } 2\end{array}$ & 2020 & 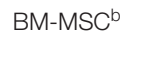 & Allogeneic & $\begin{array}{l}\text { SBI- } 101+2.5 \times 10^{8} \text { vs. } 7.5 \times \\
10^{8}\end{array}$ & $\begin{array}{l}\text { Time of } \\
\text { hemodialysis }\end{array}$ & & \\
\hline \multicolumn{10}{|c|}{ Sepsis-Induced AKI } \\
\hline NCT02421484 & Completed & Phase 1 & 2015 & BM-MSC & Allogeneic & $\begin{array}{l}0.3 \text { vs. } 1 \text { vs. } 3 \times 10^{6} \text { cells } / \mathrm{kg} \\
\text { body mass } \\
N=1\end{array}$ & IV & $\begin{array}{l}\text { No } A E \text { or SAE } \\
\sim \text { Efficacy between treated and } \\
\text { control groups }\end{array}$ & (20) \\
\hline NCT03369275 & $\begin{array}{l}\text { Not yet } \\
\text { recruiting }\end{array}$ & Phase 2 & 2018 & BM-MSC & Allogeneic & $\begin{array}{l}3 \times 10^{6} \text { cells } / \mathrm{kg} \text { body mass } \\
N=1\end{array}$ & IV & & \\
\hline \multicolumn{10}{|c|}{ Chronic and End-Stage Kidney Disease } \\
\hline NCT02966717 & $\begin{array}{l}\text { Active, not } \\
\text { recruiting }\end{array}$ & Phase 2 & 2016 & BM-MSC & Allogeneic & $\begin{array}{l}1 \times 10^{6} \text { cells } / \mathrm{kg} \text { body mass } \\
N=2,2 \text { weeks apart }\end{array}$ & iv & & \\
\hline NCT02166489 & Completed & Phase 1 & 2014 & BM-MSC & Autologous & $\begin{array}{l}2 \times 10^{6} \mathrm{cells} / \mathrm{kg} \text { body mass } \\
N=1\end{array}$ & iv & $\begin{array}{l}\text { No AE or SAE } \\
\sim \text { Renal function }\end{array}$ & (21) \\
\hline NCT02195323 & Completed & Phase 1 & 2014 & BM-MSC & Autologous & $\begin{array}{l}2 \times 10^{6} \text { cells } / \mathrm{kg} \text { body mass } \\
N=1\end{array}$ & iv & & \\
\hline NCT03321942 & $\begin{array}{l}\text { Unknown } \\
\text { status }\end{array}$ & Phase 1 & 2017 & AT-MSC & Autologous & NA & iv & & \\
\hline NCT03939741 & Recruiting & $\begin{array}{l}\text { Phase } \\
\text { 1|Phase } 2\end{array}$ & 2019 & SVF & Autologous & $\begin{array}{l}1 \times 10^{6} \text { in } 5 \mathrm{~mL} \\
N=1\end{array}$ & iv & & \\
\hline
\end{tabular}


TABLE 1 | Continued

\begin{tabular}{lllllll}
\hline NCT number Status $\quad$ Phases & $\begin{array}{l}\text { Start } \\
\text { date }\end{array}$ & Cell source & Donor source & Dose frequency (N) & $\begin{array}{l}\text { Infusion } \\
\text { route }\end{array}$
\end{tabular}

\section{Focal Segmental Glomerulosclerosis}

NCT02382874 Completed Phase

Atherosclerotic Renovascular Disease

NCT04392206 Recruiting Disease

Phase 12020

NCT01840540 Completed Phase 1 2013

Autologous

$2 \times 10^{6}$ cells/kg body mass

$N=1$

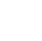

NCT02266394 Complabetic Nephropathy

NCT01843387 Completed

Phase 2013

NCT03288571 Notyet Phase 2019

recruiting 1|Phase 2

Recruiting Phase 2020

$2020 \quad$ UC-MSC

$\begin{array}{lll}\text { NCT04562025 Recruiting } & \text { 1|Phase } 2 & \\ & \text { Phase } 1 \quad 2020\end{array}$

$\begin{array}{lll}\text { NCT02585622 Recruiting } & \begin{array}{l}\text { Phase } \\ 1 \mid \text { Phase 2 }\end{array}\end{array}$

NCT04125329 Recruiting Phase 12020

NCT03840343 Recruiting Phase 12019

Allogeneic

3 vs. $5 \times 10^{6}$ cells $/ \mathrm{kg}$ body

Time of

mass

$N=1$

$1 \times 10^{5}$ vs. $2.5 \times 10^{5} \mathrm{cells} / \mathrm{kg}$

body mass

Cortical perfusion

$\uparrow$ Renal blood flow

$\downarrow$ Tissue hypoxia

$\uparrow$ GFR 3 mo follow-up

1.5 vs. $310^{8}$ cells

$N=1$

Trend to stabilized or improved

eGFR

Allogeneic

$N=3,2 \mathrm{w}$ apart in each kidney

intra-renal

$1.5 \times 10^{6} \mathrm{cells} / \mathrm{kg}$ body mass

$N=5$, course of $32 \mathrm{w}$

$1 \times 10^{6} \mathrm{cells} / \mathrm{kg}$ body mass

$N=3$, weekly

0.8 vs. 1.6 vs. $2.4 \times 10^{8}$ cells iv

$N=1$

$1 \times 10^{6}$ cells $/ \mathrm{kg}$ body mass

$N=3$, monthly

2.5 vs. $5 \times 10^{5}$ cells $/ \mathrm{kg}$ body

$N=2,3$ mo apart

Lupus Nephritis

NCT0069819

Completed Ph

$\mathrm{BM}-$

MSC/UC

MSC

NCT01741857 Completed Phase 2012 UC-MSC

$\begin{array}{lllll}\text { NCT00659217 } & \begin{array}{l}\text { Unknown } \\ \text { status }\end{array} & \begin{array}{l}\text { 1|Phase 2 } \\ \text { Phase } \\ \text { 1|Phase 2 }\end{array} & 2008 \quad \text { BM-MSC } \\ & \text { Phase 2 } & 2012 & \text { UC-MSC }\end{array}$

UC-MSC

UC-MSC

Allogeneic

$1 \times 10^{6} \mathrm{cells} / \mathrm{kg}$ body mass

$N=1$

$\downarrow$ Proteinuria

$\uparrow$ Disease improvement

$\downarrow$ Proteinuria

$N=2,7 d$ apart

$\uparrow$ Disease improvement

A

$5 \times 10^{7}$

$\sim$ Remission rates in treated and placebo groups

$2 \times 10^{6} \mathrm{cells} / \mathrm{kg}$ body mass

$N=2,7 \mathrm{~d}$ apart 
TABLE 1 | Continued

\begin{tabular}{|c|c|c|c|c|c|c|c|c|c|}
\hline NCT number & Status & Phases & $\begin{array}{l}\text { Start } \\
\text { date }\end{array}$ & Cell source & Donor source & Dose frequency $(\mathrm{N})$ & $\begin{array}{l}\text { Infusion } \\
\text { route }\end{array}$ & Results & References \\
\hline NCT03458156 & $\begin{array}{l}\text { Active, not } \\
\text { recruiting }\end{array}$ & Phase 1 & 2017 & UC-MSC & Allogeneic & $\begin{array}{l}1 \times 10^{6} \mathrm{cells} / \mathrm{kg} \text { body mass } \\
N=1\end{array}$ & iv & & \\
\hline NCT03174587 & Completed & Phase 1 & 2017 & BM-MSC & Allogeneic & $\begin{array}{l}1,2 \text { and } 3 \times 10^{6} \text { cells } / \mathrm{kg} \text { body } \\
\text { mass } \\
N=3\end{array}$ & iv & $\begin{array}{l}\text { No } A E \\
\text { Infusion was tolerated }\end{array}$ & (29) \\
\hline NCT04522505 & $\begin{array}{l}\text { Active, not } \\
\text { recruiting }\end{array}$ & Phase 1 & 2017 & BM-MSC & Allogeneic & $\begin{array}{l}1,2,3 \text { and } 10^{6} \text { cells/kg body } \\
\text { mass } \triangleleft \\
N=3\end{array}$ & iv & & \\
\hline NCT04835883 & Recruiting & Phase 2 & 2019 & BM-MSC & Allogeneic & $\begin{array}{l}2 \times 10^{6} \text { cells/kg body mass } \\
N=2,12 \mathrm{~d} \text { apart }\end{array}$ & iv & & \\
\hline NCT04318600 & Completed & Phase 1 & 2014 & $\begin{array}{l}\text { Amniotic- } \\
\text { MSC }\end{array}$ & Allogeneic & $\begin{array}{l}1 \times 10^{6} \text { cells } / \mathrm{kg} \text { body mass } \\
N=3, \text { monthly }\end{array}$ & iv & & \\
\hline NCT03917797 & Recruiting & Phase 2 & 2019 & UC-MSC & Allogeneic & NA & iv & & \\
\hline NCT03673748 & $\begin{array}{l}\text { Not yet } \\
\text { recruiting }\end{array}$ & Phase 2 & 2021 & BM-MSC & Allogeneic & $\begin{array}{l}1.5 \times 10^{6} \mathrm{cell} / \mathrm{s} / \mathrm{kg} \text { body mass } \\
N=1\end{array}$ & iv & & \\
\hline NCT02633163 & Recruiting & Phase 2 & 2018 & UC-MSC & Allogeneic & $\begin{array}{l}1 \text { vs. } 5 \times 10^{6} \text { cells } / \mathrm{kg} \text { body } \\
\text { mass } \\
N=1\end{array}$ & iv & & \\
\hline \multicolumn{10}{|c|}{ Kidney Transplant } \\
\hline NCT00659620 & $\begin{array}{l}\text { Unknown } \\
\text { status }\end{array}$ & $\begin{array}{l}\text { Phase } \\
1 \mid \text { Phase } 2\end{array}$ & 2008 & BM-MSC & Autologous & NA & iv & & \\
\hline NCT00658073 & Completed & Phase 1 & 2008 & BM-MSC & Autologous & $\begin{array}{l}1-2 \times 10^{6} \text { cells } / \mathrm{kg} \text { body mass } \\
N=2,24 \mathrm{~h} \text { and } 2 \mathrm{w} \text { after } \mathrm{Tx}\end{array}$ & iv & $\begin{array}{l}\downarrow \text { Acute Rejection } \\
\downarrow \text { Risk of opportunistic } \\
\text { infections, } \\
\uparrow \text { eGFR } 1 \text {-year follow-up }\end{array}$ & (30) \\
\hline NCT00734396 & Completed & $\begin{array}{l}\text { Phase } \\
1 \mid \text { Phase } 2\end{array}$ & 2009 & BM-MSC & Autologous & $\begin{array}{l}1 \times 10^{6} \text { cells/kg body mass } \\
N=1\end{array}$ & iv & $\begin{array}{l}\text { No AE } \\
\text { Resolution of tubulitis without } \\
\text { IF/TA in two patients }\end{array}$ & (31) \\
\hline \multirow[t]{2}{*}{ NCT00752479 } & Completed & $\begin{array}{l}\text { Phase } \\
\text { 1|Phase } 2\end{array}$ & 2008 & BM-MSC & Allogeneic & $\begin{array}{l}2 \times 10^{6} \text { cells } / \mathrm{kg} \text { body mass } \\
N=1,7 \mathrm{~d} \text { post } \mathrm{Tx}\end{array}$ & iv & $\begin{array}{l}\uparrow \text { Serum Creatinine > Acute } \\
\text { Graft Dysfunction } \\
\uparrow \text { Regulatory T cells } \\
\downarrow \text { Memory CD8 }{ }^{+} T \text { cells }\end{array}$ & (32) \\
\hline & & & & & & $\begin{array}{l}2 \times 10^{6} \text { cells/kg body mass } \\
N=1, T x\end{array}$ & iv & $\begin{array}{l}\downarrow \text { Memory CD8+ T cells } \\
\downarrow \text { Donor-specific CD8+ T cell } \\
\text { cytolytic response } \\
\uparrow \text { Expansion of } \\
\mathrm{CD} 4^{+} \mathrm{CD}^{+} 5^{+} \text {FoxP }^{+} \text {Treg cells }\end{array}$ & (33) \\
\hline NCT02012153 & Recruiting & Phase 1 & 2013 & BM-MSC & Autologous & $\begin{array}{l}2 \times 10^{6} \mathrm{cells} / \mathrm{kg} \text { body mass } \\
N=1,1 \mathrm{~d} \text { before } \mathrm{Tx}\end{array}$ & iv & $\begin{array}{l}\uparrow \text { Graft function for } 5 \text { to } 7 \text { years } \\
\text { follow-up } \\
\downarrow \text { CD8+ T cell in } 3 \text { of } 4 \text { patients } \\
\downarrow \text { ex vivo T cell donor-specific } \\
\text { cytotoxicity }\end{array}$ & (34) \\
\hline
\end{tabular}


TABLE 1 | Continued

\begin{tabular}{|c|c|c|c|c|c|c|c|c|c|}
\hline NCT number & Status & Phases & $\begin{array}{l}\text { Start } \\
\text { date }\end{array}$ & Cell source & Donor source & Dose frequency $(\mathrm{N})$ & $\begin{array}{l}\text { Infusion } \\
\text { route }\end{array}$ & Results & References \\
\hline & & & & & & & & $\begin{array}{l}\uparrow \mathrm{CD}^{+} \mathrm{CD}^{2} 5^{+} \mathrm{FoxP}^{+} \text {Treg cells } \\
\uparrow \text { Naiive and transitional B cells. } \\
1 \text { patient successfully } \\
\text { discontinued immunotherapy } \\
\text { with CsA }\end{array}$ & \\
\hline NCT02492490 & $\begin{array}{l}\text { Unknown } \\
\text { status }\end{array}$ & $\begin{array}{l}\text { Phase } \\
1 \mid \text { Phase } 2\end{array}$ & 2014 & SVF & Autologous & $\begin{array}{l}1 \times 10^{6} \text { cells } / \mathrm{kg} \text { body mass } \\
N=4,0,7,14,21 \mathrm{~d} \text { after } \mathrm{Tx}\end{array}$ & iv & & \\
\hline NCT02561767 & Completed & $\begin{array}{l}\text { Phase } \\
\text { 1|Phase } 2\end{array}$ & 2015 & BM-MSC & Autologous & $\begin{array}{l}1 \times 10^{6} \text { cells/kg body mass } \\
N=4,0,7,14,21 \mathrm{~d} \text { after } \mathrm{Tx}\end{array}$ & iv & $\begin{array}{l}\text { No AE or SAE } \\
\uparrow \text { GFR. Renal function stable } \\
\uparrow B \text { cell levels }\end{array}$ & (35) \\
\hline NCT02563366 & $\begin{array}{l}\text { Unknown } \\
\text { status }\end{array}$ & $\begin{array}{l}\text { Phase } \\
1 \text { |Phase } 2\end{array}$ & 2015 & BM-MSC & Allogeneic & $\begin{array}{l}1 \times 10^{6} \text { cells } / \mathrm{kg} \text { body mass } \\
N=4,0,7,14,21 \mathrm{~d} \text { after } \mathrm{Tx}\end{array}$ & iv & & \\
\hline NCT02490020 & Completed & Phase 1 & 2016 & UC-MSC & Allogeneic & $\begin{array}{l}\text { iv: } 2 \times 10^{6} \mathrm{cells} / \mathrm{kg} \text { body mass, } \\
48 \mathrm{~h} \text { before } \mathrm{Tx} \\
+/- \\
\text { ia: } 5 \times 10^{6} \mathrm{cell} / \mathrm{kg} \text { body mass, } \\
\text { during } \mathrm{Tx} \\
N=2\end{array}$ & $i v+i a$ & $\begin{array}{l}\text { No AE } \\
\text { No MSC engraftment } \\
\rightarrow \text { Post-operative complications } \\
\rightarrow \text { eGFR }\end{array}$ & $(36,37)$ \\
\hline NCT02563340 & $\begin{array}{l}\text { Unknown } \\
\text { status }\end{array}$ & $\begin{array}{l}\text { Phase } \\
1 \mid \text { Phase } 2\end{array}$ & 2015 & BM-MSC & Allogeneic & $\begin{array}{l}1 \times 10^{6} \mathrm{cells} / \mathrm{kg} \text { body } \\
N=4,2 \mathrm{w} \text { apart }\end{array}$ & iv & & \\
\hline NCT02492308 & $\begin{array}{l}\text { Unknown } \\
\text { status }\end{array}$ & $\begin{array}{l}\text { Phase } \\
\text { 1|Phase } 2\end{array}$ & 2014 & SVF & Autologous & $\begin{array}{l}1 \times 10^{6} \text { cells/kg body } \\
N=4,0,7,14,21 \mathrm{~d} \text { after Tx }\end{array}$ & iv & & \\
\hline NCT02409940 & Completed & Phase 1 & 2013 & BM-MSC & $\begin{array}{l}\text { Allogeneic/ } \\
\text { Autologous }\end{array}$ & $\begin{array}{l}0.2-3 \times 10^{6} \text { cells } / \mathrm{kg} \text { body } \\
N=2,1 \mathrm{~d} \text { pre- and } 30 \mathrm{~d} \text { post- } \mathrm{Tx}\end{array}$ & iv & $\begin{array}{l}\text { No AE or SAE } \\
\uparrow \text { Graft function } \\
\uparrow \mathrm{CD} 4^{+} \mathrm{CD} 25^{+} \text {FoxP }+ \text { Treg cells } \\
\downarrow \mathrm{CD} 4^{+} T \text { cell proliferation }\end{array}$ & $(38,39)$ \\
\hline NCT02565459 & Recruiting & Phase 1 & 2015 & BM-MSC & Allogeneic & $\begin{array}{l}1 \mathrm{vs} .2 \times 10^{6} \text { cells } / \mathrm{kg} \text { body } \\
\text { mass } \\
N=1, \mathrm{Tx}\end{array}$ & iv & & \\
\hline NCT02387151 & Completed & Phase 1 & 2015 & BM-MSC & Allogeneic & $\begin{array}{l}1.5-2 \times 10^{6} \text { cells } / \mathrm{kg} \text { body } \\
\text { mass } \\
N=2\end{array}$ & iv & & $(40)$ \\
\hline NCT02057965 & $\begin{array}{l}\text { Active, not } \\
\text { recruiting }\end{array}$ & Phase 2 & 2014 & BM-MSC & Autologous & $\begin{array}{l}1 \mathrm{vs.} 2 \times 10^{6} \text { cells } / \mathrm{kg} \text { body } \\
\text { mass } \\
N=2,6 \text { and } 7 \mathrm{w} \text { after Tx }\end{array}$ & iv & & (41) \\
\hline NCT03478215 & Recruiting & Phase 2 & 2016 & BM-MSC & Autologous & $\begin{array}{l}1,2 \text {, and } 3 \times 10^{6} \text { cells } / \mathrm{kg} \text { body } \\
\text { mass } \\
N=1\end{array}$ & iv at surgery & & \\
\hline NCT01429038 & Completed & $\begin{array}{l}\text { Phase } \\
1 \mid \text { Phase } 2\end{array}$ & 2012 & BM-MSC & Allogeneic & $\begin{array}{l}1.5 \text { vs. } 3 \times 10^{6} \text { cells } / \mathrm{kg} \text { body } \\
\text { mass } \\
N=2,3 \text { and } 5 \text { d post } T x\end{array}$ & iv & $\begin{array}{l}\text { No MSC engraftment } \\
2 \text { Kidney/MSC HLA MM } \\
1 \text { MSC MM }\end{array}$ & (42) \\
\hline
\end{tabular}

MSC From Commercial Entities: ${ }^{a}$ AC607 (AlloCure Inc.), bSBI-101 plasmapheresis device in combination with MSC (Sentien Biotechnologies Inc.), ${ }^{c}$ Rexlemestrocel-L (Mesoblast Ltd.), ${ }^{d}$ ORBCEL-M ${ }^{T M}$ (Orbsen Therapeutics Lt.).

$\sim$, Similar; $\uparrow$, Increase; $\downarrow$, Decrease; $\triangleleft$, Dose-escalated study.

AE, Adverse events; AKI, Acute Kidney Injury; AT, Adipose Tissue; BM, Bone Marrow; CSA, Cyclosporin A; d, day; eGFR, estimated Glomerular Filtration Rate; GFR, Glomerular Filtration Rate; HLA, Human Leukocyte Antigen; ia, intra-arterial; IF, Interstitial fibrosis; iv, intra-venous; Kg, Kilogram; MM, Mismatch; mo, month; MSC, Mesenchymal Stromal Cell; NA, Not Available; SAE, Severe adverse events; SVF, Stromal Vascular Fraction; TA, Tubular Atrophy; Treg, Regulatory T cells; Tx, Transplant; UC, Umbilical Cord; w, week; y, year. 


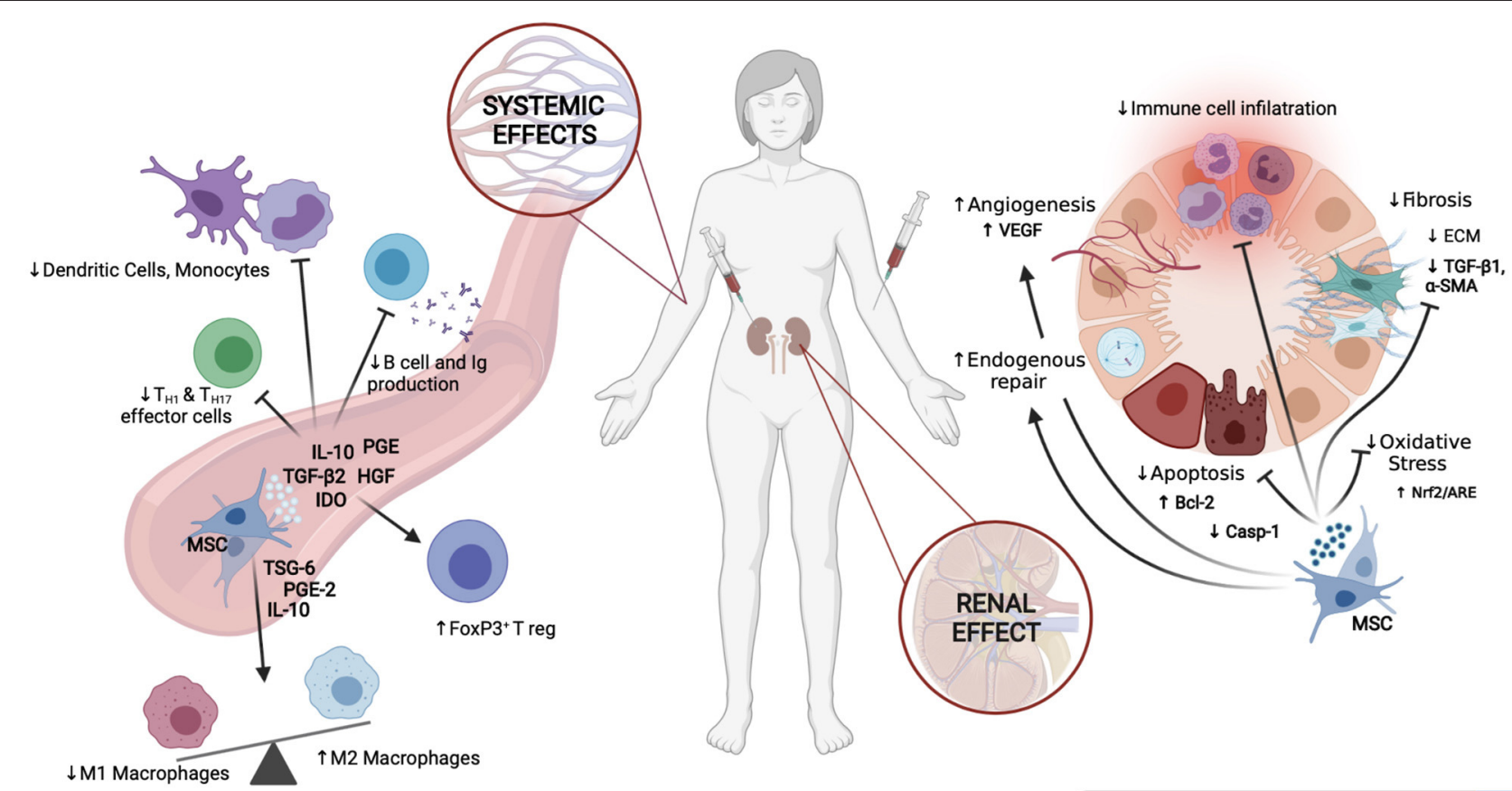

Created in BioRender.com bio

FIGURE 1 | Mechanisms of action of MSCs in kidney disease. At the renal level, MSCs enhance endogenous mechanisms of repair, confer cytoprotection by dampening apoptosis and oxidative stress, promote vascular preservation and regeneration, diminish renal fibrosis and reduce infiltration of immune cells, creating an anti-inflammatory and pro-regenerative environment. At the systemic level, MSCs inhibit the pro-inflammatory activities of both, the innate and adaptative immune system, enhancing the expansion of tolerogenic T reg and M2 Macrophages while inhibiting M1 macrophages, monocytes, dendritic cells, and T and B lymphocytes. Created in BioRender.com.

processing variables that are important to consider during the scale-up and manufacture of the cell product. As part of this study, we conducted a search in the ClinicalTrials.gov database of current registered clinical trials on kidney disease. According to our search, fifty-four clinical trials are being or have been conducted around the world to study the safety and efficacy of MSC-based ATMPs in a variety of renal diseases (accessed in April 2021, https://clinicaltrials.gov) (Table 1). We acknowledge that this list may not be exhaustive as it is derived from one well-known clinical trial registry, and it is possible that some other clinical trials may be listed in other national or international registries, which have not been considered in this review. The search includes clinical studies at all different stages (completed, recruiting, or not enrolling). Search terms included: "mesenchymal stem cells," "mesenchymal stromal cells," "kidney injury," "kidney disease," "kidney transplant," combined in various modifications with "AND" and "OR." When possible, information about MSC tissue source, donor (allogeneic or autologous), and cell processing variables such as cell plating densities, passage number, culture media supplements and culture devices for cell expansion, were extracted (Table 2). When available, additional sources of information were retrieved from hand searches of relevant papers and/or websites.

\section{MSC-BASED THERAPIES IN KIDNEY DISEASES}

\section{Disease Overview}

Generally, kidney diseases have been subdivided into acute kidney injury (AKI) and chronic kidney disease (CKD), according to the duration of the injury. While AKI is described as an abrupt decline in renal function, CKD emerges after years of progressive and persistent loss of glomerular filtration rate and albuminuria $(4,5)$. Although they were originally considered two individual entities, it is now clear they share an intrinsic link: maladaptive repair following AKI leads to progressive CKD, and at the same time patients with underlying CKD are more likely to develop AKI resulting in a deterioration in renal function (82). Often asymptomatic, the progressive nature of CKD leads to a vicious cycle of injury that ultimately causes renal failure or end-stage renal disease (ESRD) (83). At the time of late-stage CKD diagnosis, renal function has declined beyond physiological reserve and kidney failure is diagnosed. Despite significant advances in understanding the pathophysiology of AKI and CKD, current therapeutic and pharmacological approaches only offer supportive treatment to handle and manage underlying complications (84). In recent years MSCs and their derived by-products, mainly paracrine signals and extracellular vesicles 


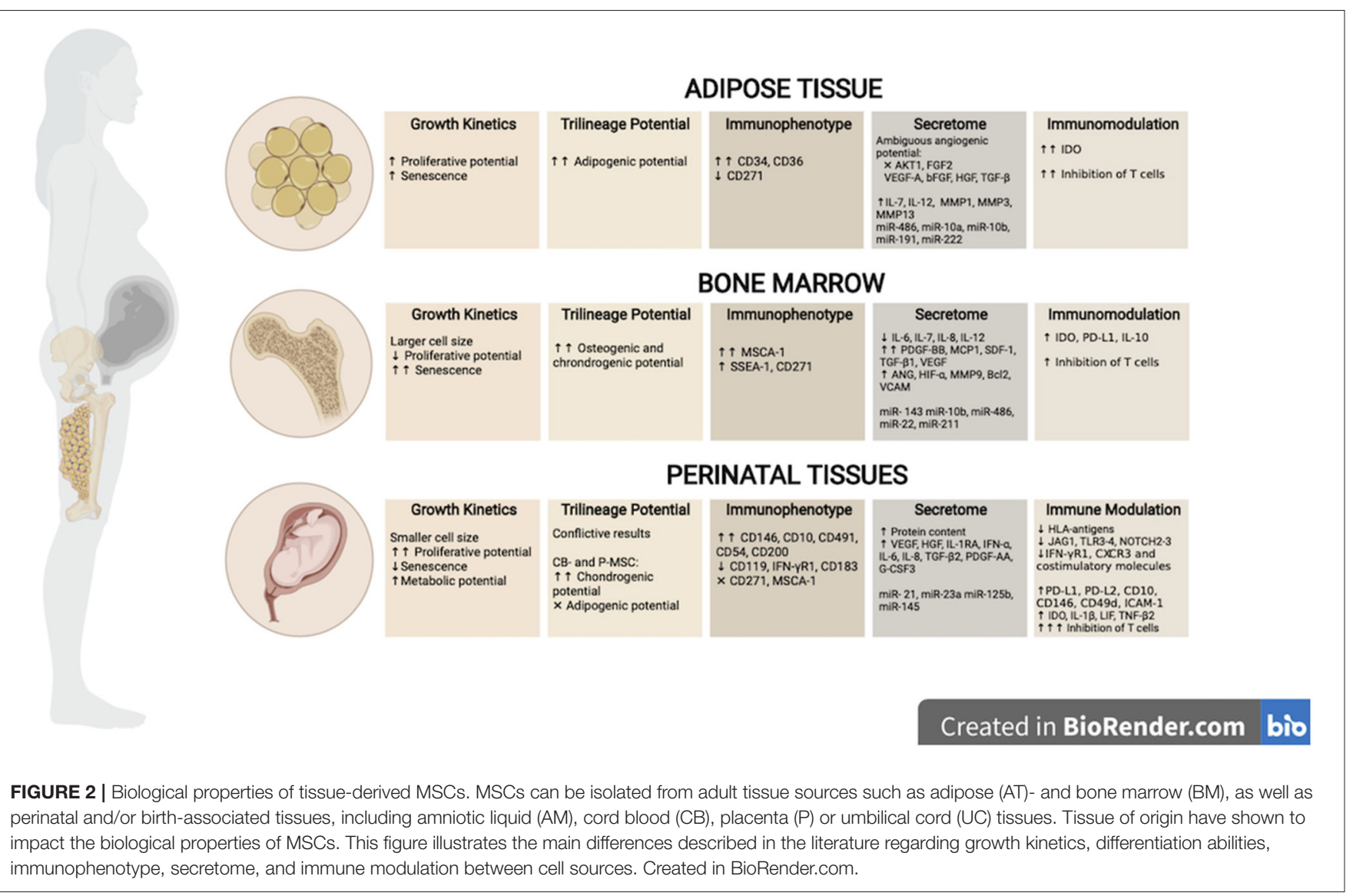

(EVs), have emerged as a novel cell-based therapy to treat acute and chronic kidney injury. Herewith, this section reviews the growing body of preclinical and clinical evidence on the potential role of MSCs in recovery after kidney damage.

\section{Mechanisms of Action of MSCs in Kidney Disease \\ MSCs in Acute Kidney Injury}

AKI is considered a severe clinical syndrome in hospitalized patients, with a prevalence of $1-9 \%$, and is especially common among critically ill patients, affecting $45 \%$ of patients admitted to the intensive care unit (85). The abrupt decline in renal function is accompanied by an alteration of the homeostasis within the kidney. The decline in glomerular filtration rate results in accumulation of serum creatinine, blood urea nitrogen (BUN), and/or reduction in urine output (85). Along with the original insult, functional disturbances cause a reduction in renal cell mass due to cell death, impairing renal function and facilitating the subsequent progression to fibrosis. Notwithstanding all efforts to manage the associated clinical manifestations, AKI is still considered an independent risk factor for mortality and development of CKD (86). Within the multiple etiologies of renal injury, ischemia-reperfusion injury (IRI) is the most prevalent form of AKI, together with vascular obstructions within the renal circuit (85), and drug-induced nephrotoxicity (87). IRI is also an unavoidable event during kidney transplantation, limiting graft functionality and increasing the risk of rejection and graft loss (88).

Inflammation plays a central role throughout the process of kidney injury (89). Shortly after the injury, activation of inflammatory pathways induces the recruitment and infiltration of leukocytes such as neutrophils, monocytes, and dendritic cells. $\mathrm{T}$ and $\mathrm{B}$ lymphocytes have also been linked to contributing to kidney injury. Conversely, regulatory $\mathrm{T}$ cells and M2 macrophages are essential in suppressing inflammation, enhancing tissue remodeling and causing repair. However, if uncontrolled, the endogenous mechanisms of tissue repair within the kidney could promote additional damage and irreversible fibrosis (90). Together, the immune system, the ischemic environment and the endogenous mechanisms of repair converge in a complex milieu of profibrotic and proinflammatory cytokines and chemokines. In this context, MSCs have been proposed as powerful candidates to dampen the severity of AKI and promote effective regenerative processes.

Infusion of MSCs in several in vivo models of AKI has resulted in improved renal function by decreasing tubular injury, promoting angiogenesis, reducing oxidative stress as well as inflammation, promoting a pro-regulatory and antiinflammatory phenotype (91-93). The main mechanisms whereby MSCs have been found to elicit such renoprotective effects are related to paracrine signaling and shedding of 
TABLE 2 | Summary of MSC culture processing variables publicly available from clinical trials of KD.

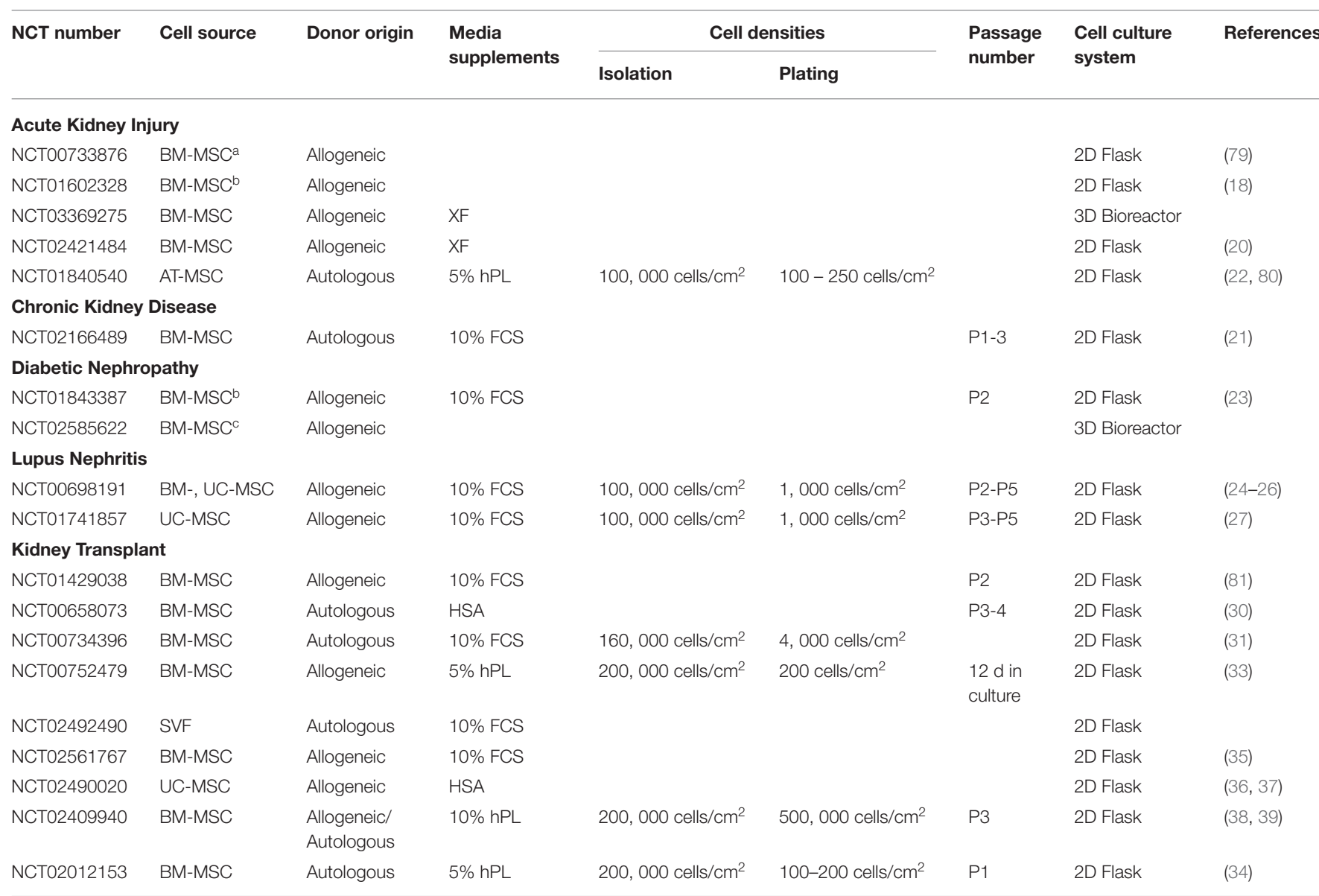

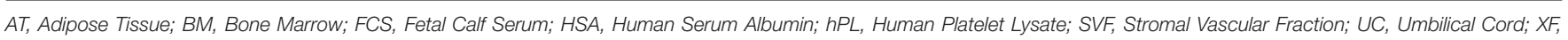
Xenofree media.

MSC Commercial Names: ${ }^{a} A C 607$ (AlloCure Inc.), ${ }^{b}$ Rexlemestrocel-L (Mesoblast Ltd.), ${ }^{C} O R B C E L-M{ }^{T M}$ (Orbsen Therapeutics Lt.).

extracellular vesicles $(79,94)$. MSC-based therapies have been proven to stimulate the regeneration of tubular epithelial cells by increasing intra-renal levels of HGF (95-97) and TSG6 (98), promoting the activation of pro-survival pathways such as AKT/ERK (99); decreasing tubular apoptosis, by upregulating Bcl2 and downregulating Caspase 3 (100), and inhibiting the endoplasmic reticulum stress response (99). Moreover, MSCs help in counterbalancing the oxidative damage by enhancing the activity of free radical scavengers (101), favoring the activation of the Nrf2/ARE pathway (102) and downregulating the expression of NOX2 which are key ischemia-related insults (102). A large part of the beneficial effect of MSCs is related to their interaction with both, the innate and adaptive immune systems. The complement system serves as a key moderator of the immune system and MSCs have been described to interact with this system in a synergistic manner to modulate the host immune response (103). Conversely, in the context of kidney injury, MSCs have been found to inhibit the overactivation of the complement cascade, decreasing serum levels of $\mathrm{C} 5 \mathrm{a}$ as well as intra-renal deposits of C3 and C5aR $(104,105)$. Downregulation of inflammatory cytokines such as TNF $\alpha$, MMP9, ICAM1,
$\mathrm{NF} \kappa \mathrm{B}(100,106,107)$ and chemokines such as CX3CL1 (108), CXCL2, and IL6, decreased the infiltration of pro-inflammatory macrophages (109) and effector $\mathrm{T}$ cells while promoting the presence of regulatory T cells (110). This "shift" toward an anti-inflammatory profile seems to be, in part, governed by the expression of IL10 (111) and adherence factors such as ICAM1 and VCAM1 (112). The secretion of pro-angiogenic factors [e.g., VEGF, eNOS (113-116)] has been shown to improve capillary rarefaction (107), dampening the ischemic damage and preventing the progression of interstitial fibrosis $(108,110)$.

Interestingly, in vitro experiments have found that small single-stranded non-coding RNA molecules (miRs) contained within EVs produced by BM-MSCs can protect proximal tubular epithelial cells after ischemia by targeting the expression of mRNAs associated with apoptosis, cytoskeleton reorganization, fibrosis, and hypoxia (117), endowing EVs and their miR cargos with interactive roles in the regenerative process.

Recently, a novel mechanism of action has been proposed whereby MSCs could rescue damaged tubular cells by targeting mitochondrial dysfunction and sustaining their energy supply (118), and restoring physiological dynamics (119). Another 
consideration in the therapeutic use of MSCs is the use of genetic modification (120-122) as well as pre-conditioning strategies such as hypoxic culture conditions (123-125), and priming of cells (126-128), which have showed superior therapeutic potential compared to that of unmodified controls (129).

\section{MSCs in Chronic Kidney Injury and End-Stage Renal Disease}

CKD emerges as the result of continuous kidney damage and scarring mediated by a dysfunctional inflammatory status (130, 131). The perpetuation of the injury is often a result of high blood pressure, nephrolithiasis, and several underlying conditions such as diabetes mellitus (10), systemic lupus erythematosis (132), or glomerular pathologies (133), as well as the development of de novo AKI (134). Regardless of the initial insult, the exacerbated renal fibrosis response that occurs throughout the course of the disease induces morphological alterations with physiological and functional consequences (135). Progression to ESRD is, therefore, inevitable.

Paracrine signaling and/or EVs derived from MSCs have been transiently found within the glomeruli and injured tubules, limiting the extent of the injury by alleviating interstitial fibrosis, recruiting leukocytes, and activating intrinsic repair mechanisms that prevent AKI-CKD transition (136-139). Similar effects have been described in several models of established CKD, where cell and cell-free strategies resulted in reduced accumulation of fibrotic tissue as a result of decreased expression of extracellular matrix components and increased capillary density, attenuation of the pro-fibrotic and pro-inflammatory environment, and promotion of M2 anti-inflammatory macrophages (140-142). However, attenuation of inflammation is not always achieved, probably due to differences in treatment time and frequency (143). In these circumstances, "licensing" strategies have proven to be efficient in promoting an early onset of MSC therapeutic effects (128).

Several studies have also explored MSC therapies in chronic scenarios where renal damage is being perpetuated by underlying pathologies, predominantly autoimmune nephritis caused by systemic lupus erythematosis (SLE) and microvascular complications of diabetes mellitus, commonly referred to as diabetic nephropathy (DN). In both scenarios, preclinical models have described the usefulness of MSCs in ameliorating the pathogenic manifestations albeit through different mechanisms due to the different nature of the insults. MSCs in preclinical models of lupus nephritis (LN) have been shown to act by suppressing the activation of the humoral and cellular immune response, evoking a systemic pro-tolerogenic milieu (144146). Besides regulating leukocyte infiltration and inhibiting proinflammatory cytokines, beneficial actions in DN models have been also attributed to the reduction of systemic biochemical alterations and reducing renal levels of oxidative stress, apoptosis, and fibrosis while promoting renal regeneration (147-150).

\section{MSCs in Kidney Transplantation}

One of the most relevant clinical settings where MSCs have shown potential beneficial effects is renal transplantation. In murine models of kidney transplantation (KTx), infusion of autologous $(151,152)$ or syngeneic $(153,154)$ MSCs induced graft tolerance and recipient survival. The achievement of a pro-tolerogenic environment was, in part, mediated by the production of indoleamine 2, 3 dioxygenase (IDO), crucial in generating regulatory $\mathrm{FoxP}^{+} \mathrm{T}$ cells $(112,151)$. The effect was increased when BM-MSCs were licensed with the pro-inflammatory cytokine IL17A $(152,155)$. However, administration of MSCs was found to only elicit a tolerogenic response and enhanced graft survival when administered following graft transplantation $(112,153,154)$.

Comparable effects have been reported in rodent models where single $(156,157)$, and multiple (158) administrations of MSCs resulted in significant improvement in graft function and attenuated expression levels of pro-inflammatory cytokines (156-158). Licensing with TGF $\beta 1$ (159) or genetic modifications to overexpress CXCR4 (160) enhanced the immunosuppressive abilities and showed an increased induction of regulatory $\mathrm{T}$ cells and anti-inflammatory cytokines. Beneficial effects have also been reported in attenuating cellular infiltration and tubular damage due to chronic graft rejection $(156,161,162)$. In contrast with this favorable preclinical evidence, other studies have reported that administration of MSCs and their derived EVs did not exert similar beneficial effects $(163,164)$, highlighting the impact of timing and synergistic immunosuppressive strategies to ensure robust therapeutic effects.

\section{Clinical Translation of MSC Therapies in Kidney Disease}

Promising preclinical results, described above, have led to earlyphase clinical studies that investigate the safety and efficacy of MSC-based therapies in a wide range of renal pathologies. Based on data compiled from studies registered on clinicaltrials.gov (accessed in April 2021), a total of 54 been registered since 2008. The main results of our search are summarized in Figure 3 and expanded in Table 1, which present an overview of the clinical use of MSCs in kidney disease highlighting heterogeneity in terms of tissue source and product development characteristics. Results from this search showed that MSCs have been most commonly used to improve outcomes of kidney transplant procedures (31.5\%), targeting either induction of allograft tolerance or minimizing the use of immunosuppressive drugs. Other trials have focused on the renoprotective potential of MSCs in lupus nephritis (24\%), AKI (14.8\%), diabetic nephropathy (13\%), and CKD/ESRD (16.7\%) (Figure 3A). Nevertheless, MSC therapies for these conditions have yet to reach later stage clinical trials and market authorization (Figure 3B).

Results from our literature search have also highlighted the great heterogeneity within the field in terms of donor and tissue source, mode of cell delivery and cell dose (Table 1). During the last decade, BM-MSCs have been the predominant cell source in clinical trials (7). However, clinical MSC products have greatly diversified in the past decade, with equal use of BM-, AT-, and PT-MSC products in clinical trials $(44,165)$. In the kidney disease clinical arena, the use of BM-MSCs remains the predominant source $(58 \%)$, although in the past 10 years a diversification 


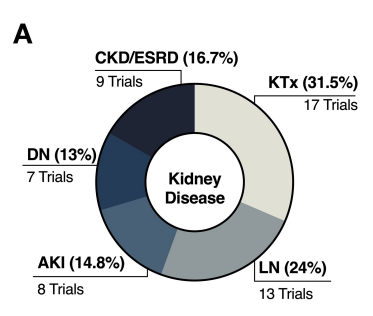

D

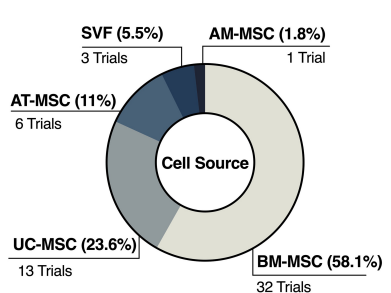

B

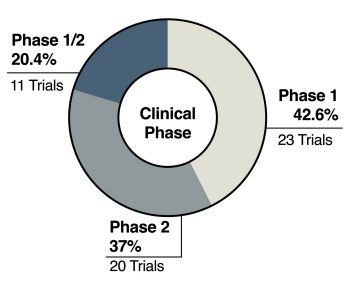

E

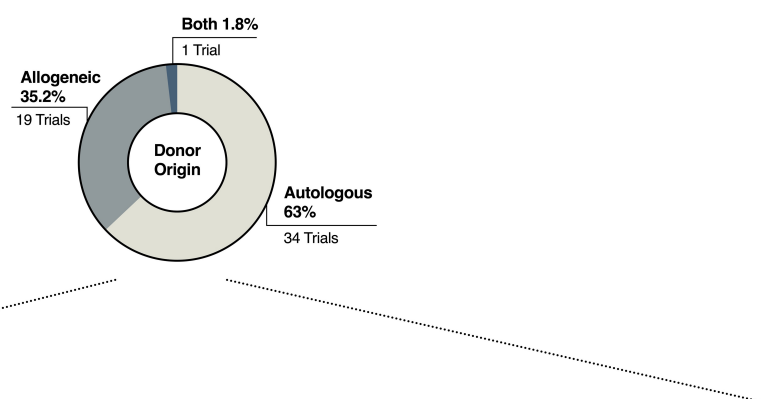

ii)

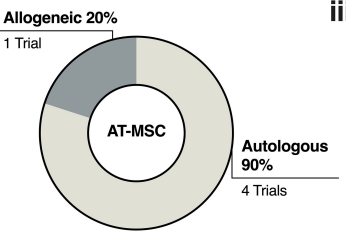

iii)

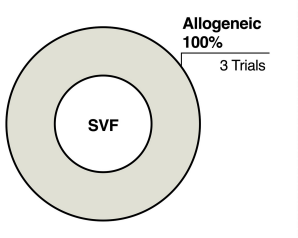

C

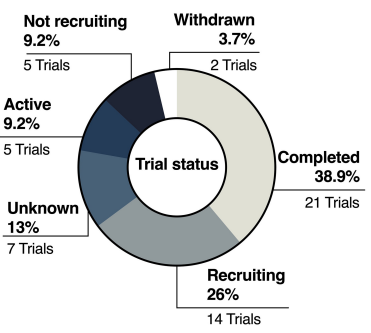

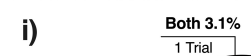

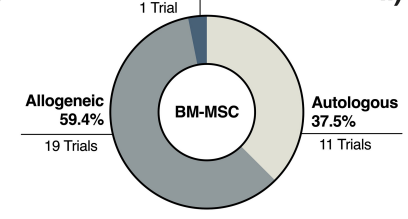

F

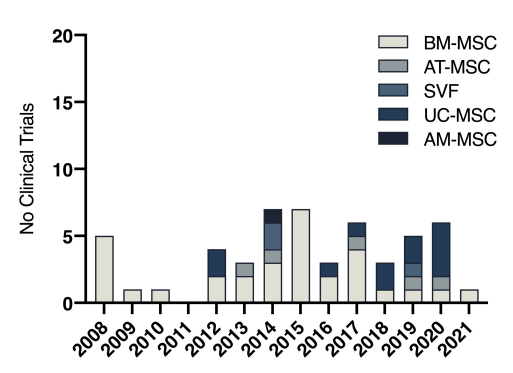

Year

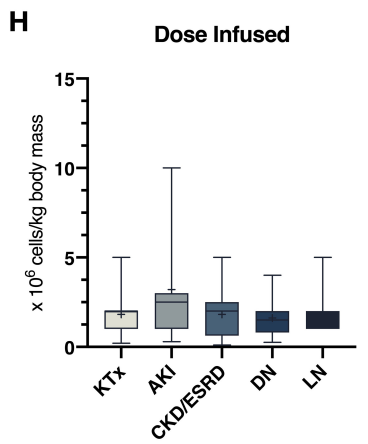

G

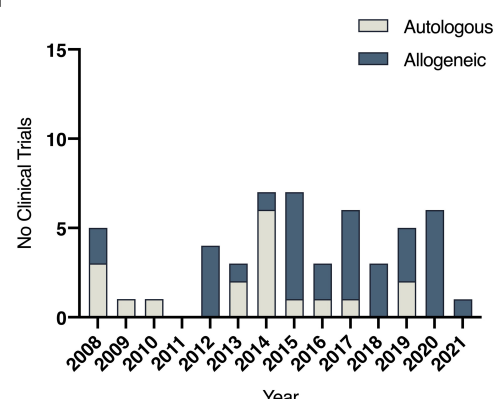

Year
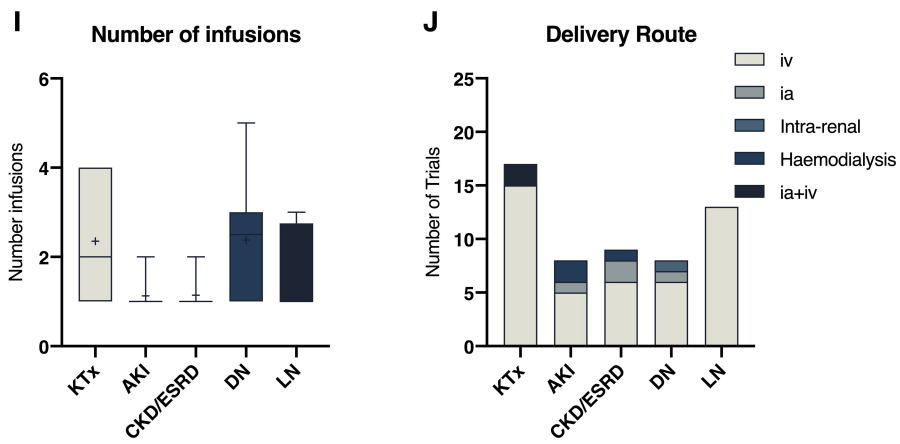

FIGURE 3 | Descriptive data related to clinical trials in kidney diseases comparing the number of trials per disease (A), clinical phase of the studies (B) and their status (C). (D,E) Illustrate the heterogeneity of cell and donor source across all studies, while $\mathbf{( F , G ) ~ d e p i c t s ~ t h e ~ c h a n g e ~ o f ~ c e l l ~ a n d ~ d o n o r ~ s o u r c e ~ p r e f e r e n c e s ~ o v e r ~ t h e ~ y e a r s . ~}$ (H-J) illustrate protocol differences across different disease settings related to dose of MSC infused $(\mathbf{H})$, frequency of infusions $(\mathbf{I})$ and choice of delivery route $(\mathbf{J})$. 
on the use of different MSC sources have also been noted (Figures 3D-G).

Most trials have used intravenous delivery (Figure 3J), despite studies which have shown that the majority of MSCs are trapped within the pulmonary circuit $(166,167)$. Some studies have explored the combination of intra-arterial delivery, to facilitate homing of the cells within the kidney, and intravenous infusion $(35,36)$. Nevertheless, in both cases, hemocompatibility and levels of procoagulant tissue factor (TF/CD142) should be considered to avoid the onset of the instant blood-mediated inflammatory reaction (IBMIR), as it is an important aspect for the safety and efficacy of these therapies (168). Although clinical protocols have added anti-thrombotic drugs to ensure the safety of MSC products (169), several studies have reported that TF/CD142 expression varies between MSC tissue origin and is highly impacted by culture processing as well as cell-dosage $(44,168,170)$. Given the procoagulant nature of MSCs, safety characterization is of utmost importance and even more so in patients undergoing organ replacement therapies that carry the burden of strong immunosuppressive regimes and their side effects such as increased cardiovascular risk $(56,171)$.

With the increasing presence of allogeneic therapies in the past years (Figure 3G), greater considerations should also be placed on the potential impact of MSC immunogenicity and the generation of alloreactive immune responses, as little is known of its long-term clinical implications $(172,173)$. Despite the presence of extensive evidence showing anti-donor cellular and humoral immune responses following administration of allogeneic MSCs (174, 175), presence of donor-specific human leukocyte antigen (HLA) antibodies has been minimally considered previously (172). This will represent a major risk when repeated injections are being included in therapeutic procedures for potentially pre-sensitized patients such as those undergoing kidney transplantation $(56,173)$.

Finally, another aspect to consider is whether MSCs are delivered as culture-adapted or "fresh" cells, with optimal metabolic fitness, or cryobanked "off-the-shelf" cells, which are thawed immediately prior to transplantation. While this is an important aspect for efficacy and safety of MSC therapies, results from our search, and others (176), have reported that the method of cell delivery (fresh vs. cryobanked), is often omitted or not clearly stated in manuscripts. The tendency to use cryobanked "off-the-shelf" cells has increased over time $(48,176)$, most likely due to the logistic advantages of this approach. However, controversy revolves around the use of banked products, with studies demonstrating reduced therapeutic potential, loss of functionality and increased susceptibility to trigger prothrombotic events (177-181), while others have showed minimal impairment of cell viability and fitness $(182,183)$. In this context, clinical potency has been linked with the concept of metabolic fitness and product viability at the time of infusion $(184,185)$ making it critical to develop manufacturing methods to rescue cryopreserved cells and restore cell functionality (186). Intriguingly, other studies have demonstrated that apoptotic or dead MSCs, and therefore less metabolically active, confer therapeutic benefits by enhancing the host innate immune response (187-189). Gaining better mechanistic insights behind the benefits that MSC therapies elicit, may it be due to viable cells, their derived by-products or rather by immune activation through dying/dead cells holds the key to elicit better therapeutic outcomes $(186,190)$.

\section{Kidney Transplantation}

Based on their immune-privileged characteristics, MSCs have been administered in conjunction with RRT to promote graft tolerance and control the host immune system with hopes of enhancing the withdrawal or minimization of immunesuppressive therapies and enhancing organ function. Initial results from a pilot study published by Perico et al. revealed the importance of timing of cell delivery. Autologous infusion of BM-MSCs in two patients seven days after undergoing KTx from a living related donor caused a severe decline in renal function and humoral and cellular acute rejection (32). The post-surgery subclinical inflammatory environment upon which MSCs were transplanted seemed to favor the development of a pro-inflammatory phenotype that could have contributed to an early graft dysfunction (154). Pretransplant administration did not result in impaired graft function, highlighting the paramount relevance of protocol optimization (33). Moreover, it showed a pro-tolerogenic graft environment supported by reduced effector $\mathrm{CD}^{+} \mathrm{T}$ cells and expanded regulatory $\mathrm{CD} 4^{+} \mathrm{FoxP}^{+} \mathrm{T}$ cells that led to stable graft function after long-term follow-up (34). In one patient, long-lasting counterbalance of regulatory/effector $\mathrm{T}$ cells and increased presence of B cells allowed the successful discontinuation of the use of ciclosporin A and tapering of the dose of immunosuppressive drugs (34).

Several other studies have provided further insights into the applicability of MSC in kidney transplant from living related $(31,35,36,38)$ and deceased donors $(36,191)$. Using kidneys from brain or cardiac deceased donors would potentially increase the number of transplant recipients and meet the growing need for kidney grafts (192). However, these procedures are associated with a higher incidence of early graft dysfunction and acute rejection as prolonged ischemic time exerts an adverse event on graft survival $(193,194)$. Recently, the combinatorial infusion of UC-MSCs before and during surgery in recipients of deceased donor grafts was proven to be safe and resulted in no adverse clinical events. However, no significant benefit was seen in terms of reduction of postoperative complications, survival rates and graft function $(36,37)$. A larger study would possibly facilitate a full assessment of improvement in delayed graft function, as a lower incidence was seen in the MSC treated group (36). In a much smaller trial, third party MSCs were infused in five kidney transplant recipients from deceased donors 3-5 days after the procedure. The 6-month safety interim report revealed no graft rejection but some degree of immunization against the shared kidney and MSC donors (191).

Despite the absence of treatment-related serious adverse events in the studies described so far, a side effect of MSC systemic immunosuppressive activity was reported in a small Phase I study, where three out of six patients developed opportunistic viral infections after MSC-infusion (31). Yet, in a much larger study involving 156 patients, inoculation of BMMSCs resulted in a significantly decreased risk of opportunistic 
infections (30). Although no neoplastia-related events have been described in KTx, this stresses the importance of carefully monitoring MSC preparations and monitoring infused patients, particularly in elderly and chronically immuno-suppressed patients with an increased risk to develop tumors and infections.

To date, a total of eight clinical trials have been completed and results published, while nine more are yet to be completed or with no publicly available results (Figure 4). The main differences between studies can be seen between the cell source and dose regimen, as well as infusion timing and frequency (Figure 4). So far, BM-MSCs have been the choice of starting material in fourteen studies (82.3\%), six using autologous (43.75\%) and eight using allogeneic cells (37.5\%); only two studies used SVF from autologous fat tissue and one from UC-MSCs (Figure 4). On review of the published literature, no conclusions can be drawn to determine differences in clinical outcomes on the tissue source.

Finally, although we have previously discussed the effects of timing, the rationale for administration weeks after surgery seems to be directed toward generating a pro-tolerogenic environment that would help in easing the withdrawal or tapering of immunosuppressive drugs (34). Results from current ongoing studies looking at whether MSCs in combination with mTOR inhibitor everolimus can be used for tacrolimus withdrawal may be able to shed light on the use of MSCs as a long-term effective immune-suppressive strategy $(40,41)$.

\section{Acute Kidney Injury}

Limited attempts with contradictory results have resulted from the exploration of the safety and efficacy of MSCs in recovering renal function after post-cardiac surgery AKI. An exploratory phase I trial studied the safety and feasibility of infusing allogeneic BM-MSCs in patients with several underlying comorbidities at high risk of developing AKI after open-heart surgery $(14,15)$. Outcomes from the first five patients showed that prevention infusion of MSCs was safe, averted postoperative decline in renal function, and decreased time of hospitalization and rates of readmission. Moreover, patients with underlying CKD had stable renal function and no disease progression after 16 months follow-up (16).

These encouraging results contrast with those from a recently published randomized, double-blind, phase II study with subjects undergoing cardiac surgery with evidence of early AKI development. Administration of commercial allogeneic MSCs (AlloCure Inc.) after AKI development did not improve the time of renal function recovery, rates of adverse events, need for dialysis or 30-day mortality (18). However, the authors recognized that infusion in an overwhelming status of the disease could have hampered the potential benefits. Further studies should aim to determine whether more favorable effects could be seen in prevention studies, such as the trial by Tögel and Westenfelder described above, rather than interventional studies when MSCs are administered after AKI onset (195).

It is well-known that sepsis, among other pathologies, can lead to the development of AKI in critically ill patients (196). A phase I study explored the safety and tolerability of administered allogeneic BM-MSCs in nine patients with septic shock (20). No infusion-associated or serious adverse events were detected, and no AKI outcomes reported. A follow-up phase II study (NCT 03369275) will further examine the efficacy of MSCs in this context.

As the regenerative medicine field evolves, new strategies are being developed to combine the use of cell-based therapies with cutting-edge biomedical devices (197-199). In this context, a phase I study is looking at the safety and tolerability of a biologic/device combination product called SBI-101 (Sentien Biotechnologies, Inc. USA). It combines a plasmapheresis device with allogeneic BM-MSCs and is designed to regulate inflammation and promote tissue repair. Two experimental cohorts using a low and high dose of MSC will be tested in AKI patients receiving continuous renal replacement therapy (NCT03015623). Furthermore, a second phase I/II trial (NCT04445220) aims to explore the use of this same device in COVID-19 patients that develop AKI.

The limited and contradictory clinical data available on the use of MSCs in AKI as well as the lack of mechanistic results challenge the possibility of drawing therapeutic roadmaps to guide the use of stromal cells in this context. Most studies related to AKI have used allogeneic BM-MSCs, emphasizing the relevance of "offthe-shelf" therapies in acute settings, where immediate therapy is needed (Figure 4). The exception is a phase I study that aimed to explore the use of autologous BM-MSCs for cisplatininduced AKI in patients with solid organ cancer (NCT01275612). Unfortunately, none of the screened patients met the primary criterion of acute renal failure, and the study was withdrawn.

In terms of cell product preparations, illustrated in Figure 4, limited data is available; intravenous administration or infusion through the left carotid or femoral artery are the preferred delivery option whereas cell doses are inconsistent within studies (Figure 4). Timing and frequency of infusion, patient selection, guided by more sensitive biomarkers (200), and cell preparation, are some of the concerns that will have to be addressed in future preclinical and clinical studies to establish reliable therapeutic strategies.

\section{Chronic Kidney Injury and End-Stage Renal Disease}

Autosomal dominant polycystic kidney disease (ADPKD) is a genetic disease characterized by progressive formation and enlargement of cysts in multiple organs that have a critical effect on kidneys. The infusion of autologous BM-MSCs in a small cohort of ADPKD patients was safe and well-tolerated albeit did not improve renal function (21).

Atherosclerotic renovascular disease is the most common cause of secondary hypertension and leads to deterioration of renal function due to insufficient vascularization and ischemia (201). Current treatments based on blood flow restoration have proven unsuccessful to recover kidney injury upon damage (202). Results from a phase I study showed increased cortical perfusion and decreased renal hypoxia after infusion of autologous AT-MSC, suggesting a beneficial effect of MSCs through amelioration of the inflammatory environment and enhancement of angiogenic properties (22).

Interestingly, not only MSCs but also their by-products are being tested for CKD. In 2016, Nassar et al. administered MSCderived extracellular vesicles from CB-MSCs in patients 


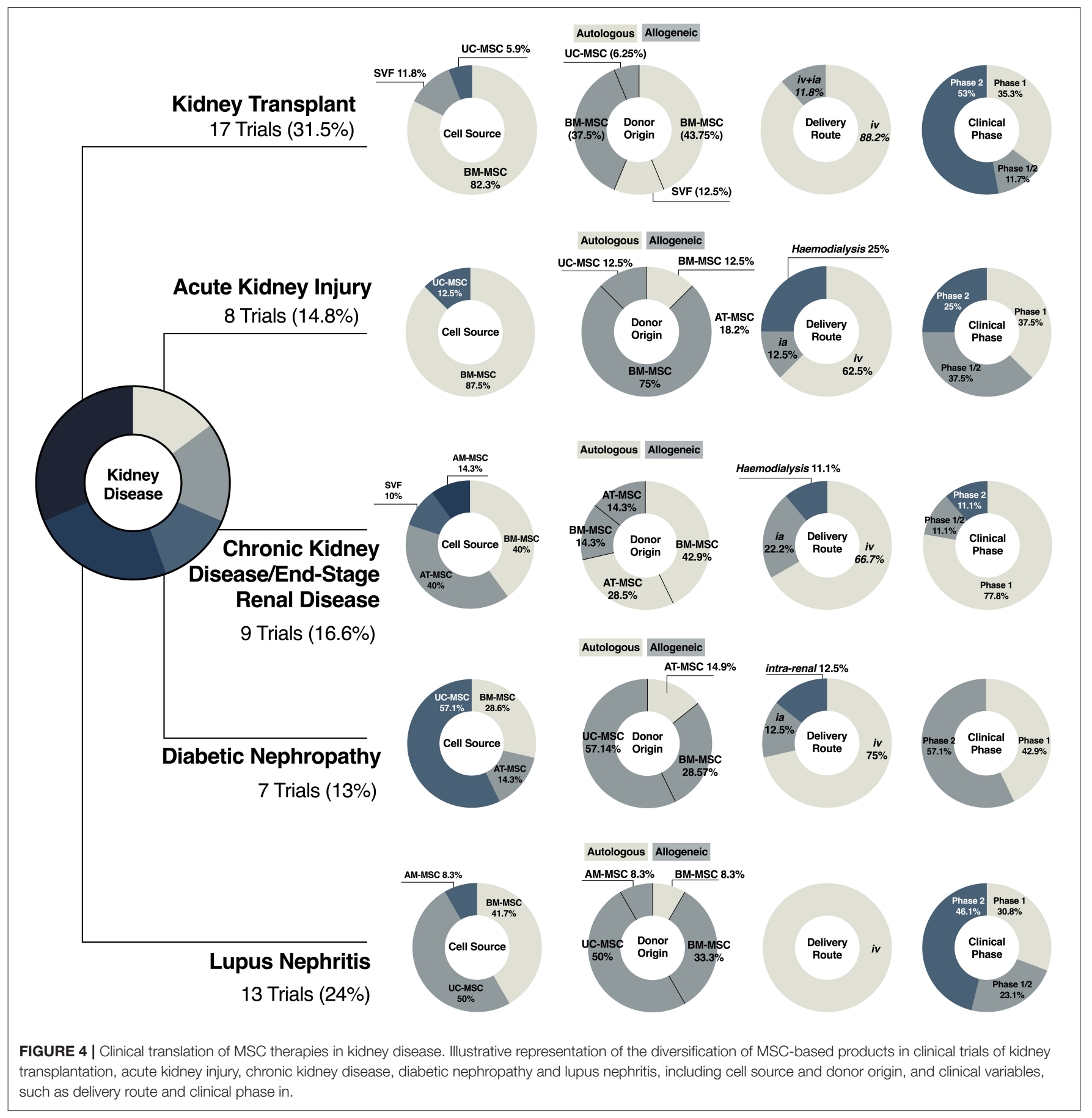

with CKD. Intravenous infusion resulted in significant improvement of renal function and increase in blood levels of immunoregulatory cytokines (203). Although preliminary, this study opens the window for novel strategies based on EVs derived from cultured MSCs with the potential of developing cell-free therapies (204).

In the context of CKD and ESRD, there is a tendency toward the use of autologous therapies, either from BM or AT. Although it has been recognized that MSC potency could be affected by disease status, several studies have supported the use of autologous strategies in CKD patients (205-207). Moreover, the use of allogeneic material is less desirable in patients likely to undergo renal replacement, as immune responses against donor antigens following MSC infusion have been documented (175). Overall, clinical protocols agree on administration route, frequency, and cell dosage (Figures $\mathbf{3 H}-\mathbf{J}, \mathbf{4}$ ). It should be considered that underlying patient characteristics, such as disease stage, and the intrinsic complexity of chronic diseases could be reducing any therapeutic benefit. 


\section{Diabetic Nephropathy}

Diabetic nephropathy (DN) is the most common cause of end-stage renal failure (208). In a multicentre, randomized, placebo-controlled, dose-escalation study conducted in Australia, the safety of two doses of allogeneic BM-MSCs product rexlemestrocel-L (Mesoblast Inc.) was tested in a cohort of patients with advanced DN. No adverse events related to the treatment were reported and patients showed trends of renal function improvement after 12 weeks (23). A similar phase I study conducted in 18 different centers across the USA in patients with type 2 diabetes, showed a decrease in glycated hemoglobin 12 weeks after infusion of the highest dose (209). Although the same MSC preparation and doses were used, improvement in glycaemic control was not observed in the Australian cohort. Both studies demonstrate that infusion of MSCs in diabetic patients is safe and well-tolerated; however, their results enhance the idea that therapeutic outcomes elicited by MSC transplantation may be largely influenced by the disease stage. Results from ongoing trials may be able to confirm the suggestive effects of MSCs in restoring renal function and potentially ameliorating biochemical alterations in DN patients.

Of interest, trials related to DN present a higher heterogeneity in choice of tissue source (five trials using UC-, two BM- and one AT-MSCs) but not in donor origin, with $85 \%$ of the trials using allogeneic sources, most likely because the impact of DM on MSCs is still under evaluation $(210,211)$ (Figure 4). Compared with other trials, protocols have included higher cell doses, with dose-escalation studies looking at fixed doses, and a range of administration frequencies, ranging from a single intravenous injection up to five doses over 32 weeks (Figure 3I).

\section{Lupus Nephritis}

Systemic lupus erythematosus is an auto-immune disease characterized by the loss of immune tolerance against selfantigens that affects tissues throughout the whole body (132). Lupus nephritis (LN) is the most common clinical manifestation (212). Considering the ability of MSCs to promote a tolerogenic environment and modulate the immune system, 13 clinical trials have explored the safety and efficacy of BM- or UC-MSCs in LN patients. In this particular scenario, therapies are mainly based on allogeneic cell products (Figure 4) due to impaired immune-modulatory properties and increased senescence in patient-derived BM-MSCs (213).

Results from successful trials identified serum levels of IFN $\gamma$ as a predictive biomarker of MSC therapeutic efficacy. IFN $\gamma$ have also been shown to stimulate the levels of IDO (214) and to have a critical role for UC-MSCs in regulating the innate immune system through up-regulation of tolerogenic dendritic cells (145).

However, conflicting results have been published reflecting the heterogeneity among SLE and LN patients, as well as the added challenge of intrinsic confounding factors such as different degrees of disease severity and treatment regimens. While a single intravenous administration of allogeneic BM- (24) and UC-MSCs (25) was proven to evoke clinical improvement and disease remission over time (215), other studies failed to reproduce the aforementioned results (26).
To date, there are 6 more registered trials where allogeneic BM- or UC-MSCs infusion have been or are being tested in safety and efficacy exploratory studies. Based on our search, similar therapeutic regimens-cell dose, frequency, and infusion route (Figures 3I, 4)- have been or are being explored, with limited success when trying to increase infusion frequencies $(28,215)$ and adjust cell dose (29). Unfortunately lack of details about product preparation limit further inter-study comparisons.

\section{BIOLOGICAL PROPERTIES OF MSCS DERIVED FROM DIFFERENT TISSUE SOURCES}

The term "MSC" is nowadays used as an umbrella term that encompasses a variety of progenitor cells retrieved from a number of different tissues. This diversity has generated significant interest in further investigating the properties of MSCs derived from different in this review we have described the preclinical and clinical use of MSCs in kidney disease in which the cells have most often been harvested from bone marrow, adipose tissue and umbilical cord. It is not clear what is the rationale for use of MSCs from a particular source and if specific properties of the cells based on tissue of origin would suggest the superiority of one. In this section, we provide a comprehensive description of the biological and functional characteristics of MSCs reported in the literature depending on their tissue source to reflect further on this consideration (Figure 2).

\section{Cell Morphology}

MSCs are widely known for exhibiting a common spindleshaped morphology, notably at the early stages of in vitro culture. Although this is the axiom from different starting tissues, cell size and morphology have been shown to vary between adult and younger sources, with perinatal-derived MSCs being relatively smaller and BM-MSCs cultures bearing heterogeneous populations (216-218). Morphological differences have also been reported between UC- and AM-MSCs even when the same genetic background was shared (216). Culturing conditions can also influence cell shape, as morphological changes have been attributed to different media compositions (219) and the use of specific supplements and growth factors (220). Besides altering lifespan, aging also influences cell morphology: older, senescent cells have a larger diameter $(54,221,222)$. Interestingly, differences in cell size at early passage have been linked with differential expansion potential and senescence levels (223).

\section{Growth Kinetics}

MSC growth is characterized by an initial lag phase, where cells attach to the growing surface, followed by a log phase when cells undergo exponential growth by mitotic division. Finally, cells reach a plateau phase in which mitotic division continues but at a slower rate, as cell division is inhibited by cell-to-cell contact. This in vitro growth pattern continues at every passage until the hallmarks of replicative senescence start to appear, such as an increase in cell size, cell cycle arrest, interruption of mitotic divisions and accumulation of cellular debris and 
stress fibers (224). For clinical and experimental purposes, MSCs must undergo ex vivo culture expansion to generate sufficient cell numbers. However, long-term culture expansion (or in vitro aging) has been shown to reduce the replicative lifespan and prompt the onset of senescence $(54,225,226)$. This is an important fact, as it may limit the usefulness of these cells in cases where a high degree of ex vivo expansion is needed such as that required for achievement of clinical therapeutic doses. Thus, in a "space race" to discover which is the best MSC source for clinical applications, the ability to withstand longer periods in culture before reaching the onset of senescence is considered to be advantageous.

Many studies have now been performed that compare the expansion potential of MSCs obtained from different tissue sources, using culture parameters such as passage number, cumulative population doubling (CPD) and doubling times (DT) to describe cellular aging. When comparing the proliferation of MSCs harvested from different tissue sources, BM-MSCs have been shown to exhibit slower proliferation rates, with DT ranging from 40 to $60 \mathrm{~h}$ depending on the culture conditions, and earlier appearance of senescence markers in relatively early passages (between passage 6 and 7) (217, 227-231). In contrast, ATMSCs have shown faster proliferation rates (DT of 20 to $45 \mathrm{~h}$ ) as well as the ability to sustain a longer time in culture (up to passage 8) without any signs of senescence (217, 230, 232-234). These differences were still evident when comparing proliferation and differentiation capacity of AT- and BM-MSCs harvested from the same individual, although significant degrees of donorto-donor variability was observed (232-234). Variables such as donor, age, sex, and disease status may have a significant effect on MSC characteristics $(50,51,53,235)$, which may discourage the use of adult sources as therapeutic agents while favoring MSCs obtained from birth-associated tissues (231). In general, these cells have exhibited higher proliferative kinetics with lower CPD over time $(217,230,236-243)$, often related to lower expression of senescence-associated markers or later onset of senescence $(229,244)$, as well as upregulation of cell cycle-related genes and DNA damage response and repair $(245,246)$. These studies reflect the intrinsic heterogeneity between MSC populations in growth kinetics. Individual populations may also contain cells at different stages of differentiation and/or different proportions of highly proliferative cells. These variables have also been shown to vary from donor-to-donor (219).

Determining novel predictive biomarkers of therapeutic potency is of utmost importance before clinical usage, and viability and metabolic fitness have been recently proposed as potency qualities (184). Metabolic status is affected after longterm in vitro expansion, and it can reflect differential stemness behavior $(242,247-249)$, as well as cell immune functionality (250). Overall, considering the need to generate enough number of cells, the proliferative and metabolic characteristics of AT- and UC-MSCs may favor their use over BM-MSCs $(251,252)$.

\section{Tri-lineage Differentiation Potential}

The ability to undergo in vitro differentiation toward mesodermal lineages is, probably, the most differential property to biologically identify MSCs (253). Several culture-differentiating conditions have been reported to demonstrate the ability of MSCs to differentiate into adipocytes, osteoblasts and chondroblasts in vitro. Reports on tri-lineage differentiation potential have been inconsistent across different laboratories, and this may be due to the diversity of in-house protocols, culture conditions and media supplements, or the divergence in the cell preparations (219) and in vitro aging (54). Moreover, studies have reported a strong "tissue memory" effect, believed to be mainly driven by epigenetic factors $(252,254,255)$. For instance, BM-MSCs present enhanced osteogenic and chondrogenic differentiation while AT-MSCs are usually more readily able to exhibit adipogenic differentiation (234, 241, 251).

Conflicting data however exists surrounding PT-MSCs as they have shown a heterogeneous potential to undergo mesodermal differentiation $(241,256,257)$. Kern et al. reported that CB-MSCs could not differentiate toward adipocytes, similar findings were also reported for PL-MSCs (238). Other investigators, besides confirming the low adipogenic potential of CB-MSC (258), have reported higher osteogenic $(247,259)$ and chondrogenic potential $(257,260)$. Differences in identical genetic background perinatal MSC sources have also been described, with strikingly inconsistent results reported from AM-MSCs (216). Finally, similar observations have been reported for UC-MSC, with some studies suggesting higher adipogenic and osteogenic abilities (243), whereas others stated reduced differentiation compared with adult sources $(240,245)$.

While the field moves toward cell-free therapies (261) and mechanisms of action are mainly driven by paracrine and immunomodulatory effects (176), assessing the degree of commitment toward mesodermal linages to determine the most effective and suitable source for cell therapy may have less relevance. However, in other circumstances understanding how these differences affect the biology of MSCs could be an attractive avenue to study biological changes occurring throughout fetal development and adulthood (258), as well as to help define therapeutic strategies where use of MSCs is heavily influenced by such differentiation, such as bone and cartilage regeneration $(262,263)$.

\section{Cell Surface Markers}

MSCs are not a homogeneous population but rather an amalgamation of different subpopulations bearing different cell surface markers. Currently, a "true" marker for MSCs does not yet exist, which makes MSC identification challenging. In an attempt to unify MSC identification and characterization, in 2006 the Mesenchymal and Tissue Stem Cell Committee of the ISCT proposed a panel of minimal surface antigens to define human MSC (253). Within this criterion, they defined that at least $95 \%$ of the stromal population should express CD105, CD73, and CD90, and lack $(\leq 2 \%)$ the expression of CD45, CD34, CD14 or CD11b, CD79alpha or CD19, and HLA class II. The negative markers are commonly used to confirm the absence of contaminant cells in MSC preparations such as hematopoietic progenitors, endothelial cells, leukocytes, and co-stimulatory molecules. The vast majority of studies have reported comparable immunophenotypic profiles that follow ISCT criteria regardless of source, although with moderate donor variability $(219,246$, 
264). In some cases, extended culture has been seen to reduce the expression of CD105 (54) and UC-MSCs have demonstrated lower (<95\%) CD90 and CD105 expression (217).

However, the ISCT criteria do not uniquely identify stromal cells, as the proposed markers are also expressed in other connective tissue cells (265). Therefore, broader flow cytometry panels have been designed to best identify MSCs beyond the minimal criteria. Most of the protocols include the assessment of CD29, CD44, CD59, CD140b, CD166, TLR4, and PDL, commonly expressed (>95\%) in human MSCs; and CD93, CD133, CD243, CD235, and SSEA1, with no or very low expression levels in human MSCs. Expression of other markers such as CD71, CD146, CD106, and CD274 has been shown to be heterogeneous, and in some cases correlates with donor age (53). Adhesion molecules such as CD44 (hyaluronic acid receptor) or $\mathrm{CD} 29$ (integrin $\beta 1$ receptor) are highly expressed in human MSCs and have been recently proposed to be included in characterization panels (266). However, expression of markers such as CD146, another key adhesion molecule, can vary between sources, being highly expressed in UC-MSCs compared with BM-MSCs $(230,237,240,264)$ and subcutaneous AT-MSCs (267). Other markers found to be increased in UC-MSC preparations are CD10, CD49d (integrin $\alpha 4$ ), CD54 (ICAM1), (240) CD200, and PDL2, whereas CD119, IFN $\gamma$ R1 and CD183 (CXCR3) are under-expressed (264). An additional marker with functional relevance that has been shown to vary greatly between sources is the coagulation factor III or tissue factor (TF/CD142) (268), with increased levels being described in in AT- and PT-MSCs compared with those of BM-MSCs populations $(170,218,269,270)$.

Other researchers have investigated whether surface markers such as CD271, SUD2, MSCA1, CD34, and CD44 could serve to selectively enrich MSC populations. Differences between sources led to different selection efficiency and changes in biological properties. For instance, only CD34 was able to successfully isolate AT- and BM-MSCs, and interestingly the positive sorted populations showed greater proliferative capacity, increased osteogenic potential and HGF expression (271). Due to their perivascular origin, higher levels of CD34 and CD36 have been reported in AT-MSCs, albeit their expression decreases early after isolation $(230,234,239)$. On the other hand, CD271 has been reported to be absent from MSC preparations in other studies $(246,272)$. Other differentially expressed markers are SSEA4 (higher in BM- and UC-MSC), MSCA1 (absent in UC-MSC, highly expressed in BM-MSC) and CD271 (high in BM-, low in AT-, absent in UC-MSC) (230, 271, 273). Nevertheless, it still remains unclear whether differences in MSC surface markers are correlated with therapeutic activity or potency (266).

\section{Secretome Profile}

It is now well-accepted that the therapeutic effects of MSCs are primarily mediated by their ability to interact and respond to environmental stimuli releasing soluble factors and EVs (274). The ability to sense changes is also translated in vitro, where cell culture conditions (219) or exposure to licensing strategies (275) can impact the secretome, highlighting plasticity and ability to adapt and respond to surroundings $(274,276)$.
The so-called MSC secretome is composed of small molecules, chemokines, cytokines, growth factors, as well as EVs $(277,278)$. The literature has shown striking differences in the composition of MSC-secretome depending on the cell source. Moreover, variable results between studies add to the heterogeneity, further challenging the process of deciphering "true" biological properties that relate to therapeutic actions. It also makes it challenging to choose a specific MSC source to best align with the pathophysiology of the target disease.

\section{Soluble Factors}

MSCs have been reported to secrete large amounts of proangiogenic, pro-proliferative, anti-apoptotic, anti-inflammatory, anti-fibrotic and matrix-remodeling soluble factors. Several studies have shown that perinatal sources of MSC have a more diverse and protein-abundant secretome, with a more complete pro-angiogenic array $(244,246,256,279)$. Although some studies failed to detect differences in functional studies $(256,279)$, others have shown in vitro superior abilities of UC- and BM-MSCs in inducing angiogenic phenotypes (246). UC-MSCs have also exhibited greater abilities to induce vessel-like structures than maternal sources of MSCs, through enhanced secretion of HGF and VEGF (280). However, a potential confounding factor in these studies is the combination of maternal and fetal cells within PL-MSC preparations, which could be limiting their angiogenic properties (280).

In contrast with studies reporting that AT-MSCs had a weaker angiogenic secretome, lacking central molecules such as AKT1 and FGF2 (246), others have demonstrated in vitro and in vivo angiogenic potential of AT-MSC preparations in a model of hindlimb ischemia, due to the secretion of VEGFA, TGF $\beta$, bFGF and HGF, well-known factors of endothelial cell survival, proliferation, and migration $(251,281,282)$.

The secretome of UC-MSCs has been reported to be enriched with anti-inflammatory cytokines such as IL1RA and IFN $\alpha$, proinflammatory cytokines such as IL6 and IL8; and mitogenic factors such as HGF, TGF $\beta 2$, PDGFAA and GCSF (240). BMMSCs, on the other hand, while secreting lower levels of IL6, IL7, IL8, and IL12, have been reported to secrete higher concentrations of PDGFBB, MCP1, SDF1, TGF $\beta 1$, and VEGF (232, 240, 251, 283), exhibiting a stronger anti-inflammatory profile that increased upon exposure to hypoxic conditions, together with the expression of other angiogenic and antiapoptotic factors such as ANG, HIF $\alpha$, MMP9 and Bcl2 $(284,285)$. Increased levels of VCAM1 in the BM-MSC cytokine profile have been related to better angiogenic paracrine activity $(275,286)$.

AT-MSCs contain large amounts of IL7 and IL12 together with several metalloproteinases (MMP1, MMP3, and MMP13) and extracellular matrix components (240). Interestingly, expression of different MMPs between AT- and BM-MSCs has been previously reported, accounting for different mechanisms to promote angiogenesis (287).

Donor-to-donor variability and heterogeneity of MSC populations make it difficult to define a "secretome profile" specific for each tissue source of MSCs. Another layer of complexity relates to the use of cell culture supplements during in vitro expansion containing growth factors which may also 
affect the secretome (246). Ultimately, dissecting the secretome of each specific MSC preparation may provide insights of their advantages in any given pathology (e.g., superior angiogenic secretome identified in BM- and UC-MSC preparations might make them an optimal source for ischemic disorders).

\section{Extracellular Vesicles and miRs}

In recent years, EVs have been proposed as a potential mechanism of therapeutic benefit of MSCs. EVs are lipid bilayer-delimited particles released by cells into the extracellular space carrying within them a range of cargos: subcellular components such as mitochondria, proteins, lipids, microRNAs (miRs), messenger RNAs (mRNAs) and transfer RNAs (tRNAs). Their roles have been described in multiple physiological and pathological process and are considered a mechanism of cell-to-cell signaling (288). MSCs secrete microvesicles (MVs) and exosomes, and both have been widely explored as cell-free alternatives to their cellular counterparts. Cell-free therapies, if able to recapitulate therapeutic efficacy of wholecell preparations, offer several advantages due to a higher safety profile, lower immunogenicity, potential to bypass the lung trapping effect, and potential inability to induce neoplastic processes (289). It has also been described that EVs suppress proinflammatory processes, reduce oxidative stress and fibrosis in several in vivo models $(290,291)$.

Currently, there is limited data available on head-to-head comparisons of the paracrine benefits of different sources of MSC. We have only been able to identify a few studies reporting differential compositions and therapeutic effects of EVs derived from different sources. Exosomes derived from EM-MSCs enriched with miR-21 have been shown to confer superior cardioprotection after myocardial infarction over that of AT- or BM-MSC (292). Furthermore, a higher content of angiogenic-related cargos in EVs from AT-MSCs, compared to BM-MSCs, has been shown to promote wound healing (293). Similar findings have been attributed to the presence of miR-125a in AT-MSCs exosomes (294) and found to be enhanced by hypoxia priming (295). Albeit limited, recent data has described higher yields of particles secreted by AM-MSCs than BM-MSCs with similar size distribution, morphology, and immunophenotype (296).

Additional studies exploring the cargo within EV preparations from various sources have also reported beneficial effects. Exosomes secreted from BM-MSCs have been found to activate signaling pathways related to wound healing and angiogenesis (297-300) while their miRNA "repertoire" has been linked with anti-fibrotic, anti-apoptotic, pro-angiogenic and proproliferative properties (301) and the modulation of the native immune system (302). Exosomes originated from UC-MSCs have been found to contribute to wound healing (303) and reduce renal fibrosis after ischemic events by increasing capillarity density, reducing cell apoptosis, and restoring mitochondrial dynamics through $\mathrm{miR}-30 \mathrm{~b} / \mathrm{c} / \mathrm{d}$ (116).

Despite the growing body of literature studying exosomes and their cargo in several settings, minimal evidence has been reported trying to underpin the molecular mechanism of action. Ferguson et al. investigated the biological processes modulated by exosomal miRs and found that targeted pathways were related to Wnt signaling, TGF $\beta$ and PDGF signaling, proliferation and apoptosis (301). Similarly, the expression profile of miRs in MSCEVs derived from different sources lacks consistency. Although several studies have compared the expression between EVs and their parental MSC [reviewed by Qiu et al. (304)], limited studies have explored differences in miRs produced by different tissue-derived MSCs. To our knowledge, only one study has investigated the full RNAome derived from AT- and BM-MSC exosomes (305).

Akin to what we have described in the MSC field, EV isolation techniques lack standardization and generate variable products that can yield substantial differences. The use of serum or human platelet lysate supplements or serum-free conditions challenges the direct comparison of the relative contribution of EVs derived from MSC and other non-EVs factors. In a recent study, Whittaker et al. reported that soluble factors, that were non-EV molecules, were essential and sufficient to stimulate angiogenesis and wound healing in vivo (306). Their results concluded that most isolation techniques generate heterogeneous preparations containing other bioactive molecules that might mislead the attribution of therapeutic benefits.

Future studies defining the properties of miRs and exosomes will help in better understanding their biological functions and implications in cell-free therapies.

\section{Immunomodulatory Properties}

The immune system plays a central role in tissue recovery after injury. MSCs interact extensively with the immune system and promote an anti-inflammatory and pro-regenerative environment that favors injury resolution and, ultimately, tissue repair $(19,307,308)$.

Many studies have demonstrated the ability of MSCs to modulate the activation, proliferation, and function of various immune cells such as $\mathrm{T}$ and $\mathrm{B}$ lymphocytes, natural killer cells (NK), dendritic cells, macrophages, and neutrophils. Such activities rely on the plasticity (309) of MSCs to produce cytokines in response to the different stages of the inflammatory process (310) and researchers are now investigating whether MSC immunomodulatory properties are influenced by their tissue of origin. Nevertheless, results from these studies are rather diverse and it is challenging to make adequate conclusions.

Some studies have compared the immunomodulatory properties of perinatal MSC, mainly UC-MSCs and CB-MSCs, with adult tissue sources (AT- and BM-MSCs). Overall, MSCs derived from perinatal tissues have the lowest expression of HLA antigens (HLA-DMA, HLA-DPB1 and HLA-DR) and immune-related genes (JAG1, TLR4, TLR3, NOTCH2, and NOTCH3) (243), together with decreased amounts of IL1 $\alpha$, IL6, IL8, (244) and increased IDO, IL1 $\beta$, LIF, and TNF $\beta 2$ in their secretome (311). UC-MSCs also have the most prominent inhibitory effects on $\mathrm{T}$ cell proliferation, in both co-culture and trans-well mixed lymphocyte reaction (MLR) in vitro assays, followed by PL-MSCs, AT-MSCs and BM-MSCs (243). Other studies however have shown greater inhibition of allogeneic $\mathrm{T}$ cell proliferation by either BM-MSCs via increased expression 
of PDL1, IL10, and TGFß1 $(230,241)$, or AT-MSCs, which have been shown to secrete higher levels of IDO $(243,312)$.

Key adhesion molecules and other immunological markers such as CD10, CD146, CD49d, ICAM1 (CD200), and PDL2 are also increased in WJ-MSC preparations, together with decreased presence of IFN $\gamma \mathrm{R} 1, \mathrm{CXCR} 3$ and other costimulatory molecules such as CD80, CD86, and CD40 $(264,313)$. In a recent in vivo study performed by Tago et al., AM-MSCs and not BM-MSCs were able to reduce local inflammation and $\mathrm{PD} 1^{+} \mathrm{CD} 8^{+} \mathrm{T}$ cell proliferation when delivered into a murine model of GvHD (314). In addition, PDL1-enriched EVs derived from UC-MSCs have been proven to be the mechanism whereby UC-MSC-EVs enhance immunosuppression (315).

In line with what has been briefly described, Mattar et al. have also highlighted the intrinsic heterogeneity of MSCs, where in vitro data also might not relate to the complex in vivo situation (316). The inflammatory context is defined by a variety of cell types and stimulating factors that are determined to influence and "license" MSCs which may adapt and change their interactions with the immune system as a result (310). Therefore, future studies should aim to decipher if similarities/disparities of in vitro results correlate to similar in vivo functions and whether biological properties can help to define cell performance, providing rationale for the use of one particular cell source for any given disease.

\section{CONSIDERATIONS FOR THE GMP-PRODUCTION OF HUMAN MSCs FOR KIDNEY DISEASE}

The regulatory agencies in the European Union (EU), United States of America (USA) and Asia, have adapted regulatory pathways to accelerate patient access to advanced therapies such as ATMPs. However, the legal frameworks for ATMPs, as well as the criteria to be met to define a product as such, differs across these regions (317-319). In Europe, MSCbased ATMPs are governed by the EU Regulation 1294/2007/EC and Directive 2009/120/EC, and its manufacturing must be compliant with European current good manufacturing practice (cGMP) guidelines (EudraLex Volume 4, Part IV). These ATMP-specific regulations have been put in place to ultimately ensure the safety and wellbeing of patients, as single alterations in the bioprocess hold the potential to alter the final product with potential risk to the patient. For this reason, in the absence of proof of product comparability, regulatory authorities are prompted to require further re-validation, which in the worst-case scenario have resulted in pre-clinical data being invalidated and clinical trial approval requiring re-authorization. Thus, optimal manufacturing variables must be considered and identified during early stages of development, as changes in the bioprocess workflow later in the translational pathway may have a significant long-term impact on the success of the therapy with time and cost consequences but also a significant time-to-market delay $(320,321)$. In addition, having full control of the process is crucial for ensuring consistent production and quality standards in terms of safety, identity, and potency, and this control can only be guaranteed by having in place systems of quality assurance (QA) and quality control (QC) across all stages of the bioprocess. While guidelines and some common criteria now exist for ATMP developers to follow, consistent clinicalgrade production of MSCs is not yet achieved due to a lack of standardization and harmonization of manufacturing processes. Critical parameters in MSC manufacturing include the source of the starting material, and culture processing conditions, such as seeding density, passage number, media supplements and culture-expansion devices, among others $(322,323)$. These parameters have been shown to be highly variable among manufacturing centers and laboratories worldwide (47-49), increasing the number of variables, as illustrated in Figure 5, that should be considered when carving therapeutic approaches in specific clinical settings such as KD.

\section{Tissue Origin}

For many years BM has been the predominant cell type in clinical trials for kidney disease (Figure 3D) and others (47, 48, 324). One of the main advantages of using BM-MSCs is the ability to use them in autologous settings without triggering anti-donor immunoreactions. However, donor-related parameters such as age, disease severity and presence of comorbidities should be considered as they have been shown to affect MSC characteristics $(53,235,325,326)$. Recent attention has been given to donor gender, as there is now increasing evidence of gender influencing MSC properties such as growth kinetics, paracrine secretion and in vivo therapeutic potential $(52,53,327,328)$. Another disadvantage of using BM-MSCs is the need for large amounts of raw material to allow for extensive ex vivo cell expansion to obtain clinical doses, as these cells constitute a rare population (only $0.001-0.1 \%$ ) within the whole bone marrow fraction (329). Finally, BM collection requires an invasive bone harvest procedure, which is accompanied by pain, risk of infection and other limitations such as patient's comorbidities that can render this procedure unsuitable.

Alternative sources such as AT have been considered for many years. Subcutaneous AT has been shown to be an abundant source of AT-MSCs, with a yield of MSC precursors 500 times higher than from an equivalent amount of BM (330). AT-MSCs can be used both in autologous and allogeneic settings, which is advantageous. In addition, AT can be easily accessible as it is discarded as medical waste in many operations, which would be useful in allogeneic settings. In autologous settings, AT is harvested by less invasive procedures than BM, such as liposuction. However, like in BM sources, the therapeutic efficacy of autologous MSC therapies may be limited by the intrinsic impact that the disease, age, and gender may have on MSCs characteristics $(50,51)$.

Thus, in the past few years, more consideration has been given to the potential use of allogeneic MSC therapies due to the hypoimmunogeneic phenotype of these cells (331). Perinatal and birth-associated tissues have become an attractive source of allogeneic MSCs for many reasons, the main being that this material is considered medical waste and discarded every day in hospitals worldwide. Also, these MSCs are obtained from 


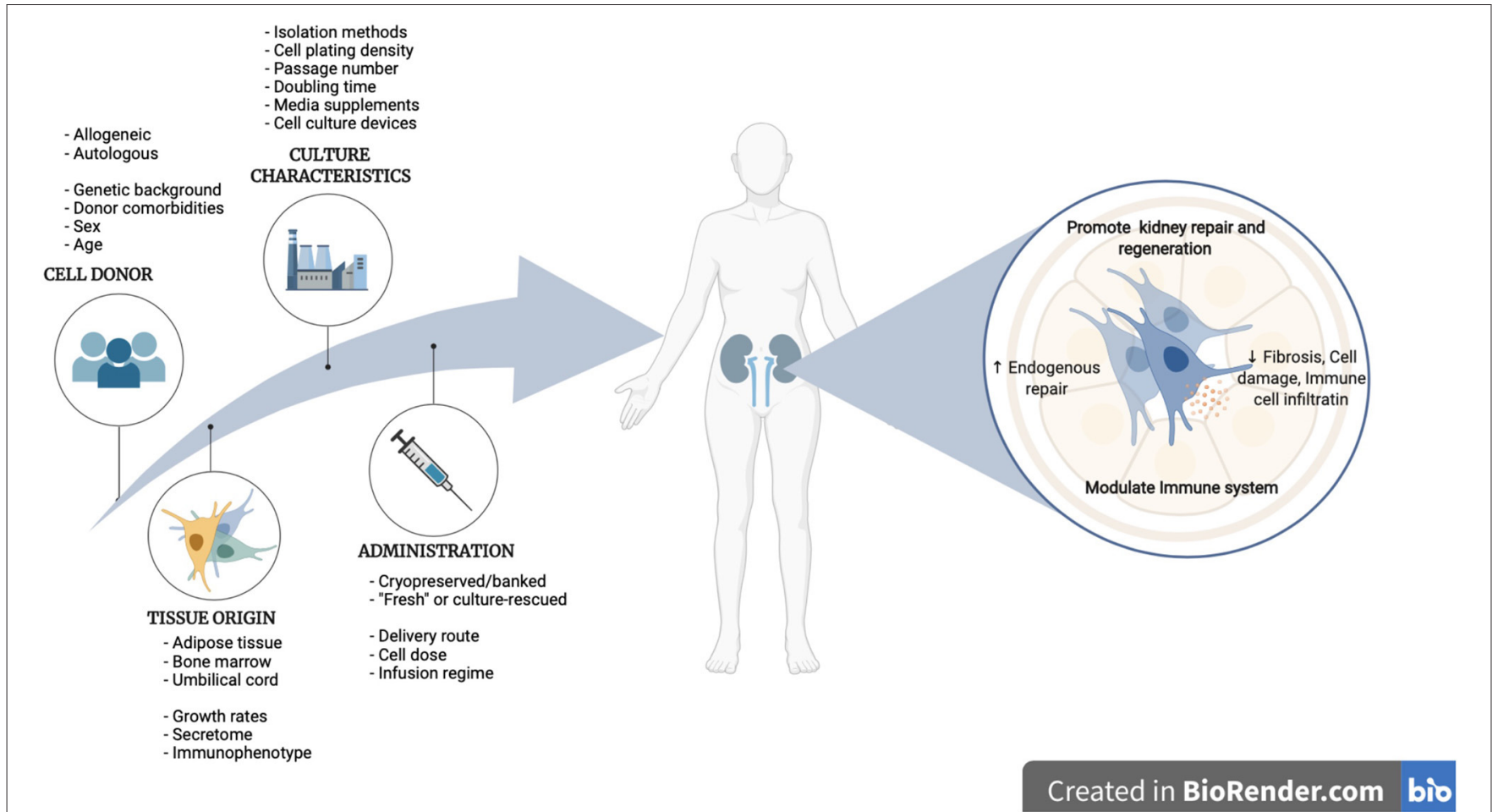

FIGURE 5 | Roadmap to clinical translation of MSC therapies for kidney disease, from MSC manufacturing variables to therapeutical benefits in renal pathologies.

the youngest donors possible (neonates), removing donor agerelated confounding effects. Perinatal tissue sources such as UC have reported isolation rates ranging from $0.2-1.8 \%$ (216), and these cells have also been shown to have significantly higher proliferation rates, compared to MSCs isolated from adult tissues (217, 237, 241).

Overall, results from our search showed that the predominant source of MSCs used in clinical trials in renal pathologies is BM (58.1\%), followed by UC (23.6\%) and AT (11\%) (Figure 3D). Also, autologous MSC therapies are predominant (62.5\%) over allogeneic. Similar trends have been also observed in other studies $(47,48,324)$. Interestingly, in renal pathologies, BMMSCs have been mostly used in allogeneic settings (59.4\%), while AT-MSCs have been used mostly in an autologous manner (80\%) (Figures 3Ei-iii).

\section{Culture Processing Characteristics}

Based on ongoing clinical trial data in kidney disease, human MSCs are transplanted at typical doses of 1-2 million cells $/ \mathrm{kg}$ and often not exceeding 10 million cells $/ \mathrm{kg}$ (Table 2). Doing a basic dose extrapolation, for an $80 \mathrm{~kg}$ person the estimated human MSC doses per patient would range between 80 and 800 million cells per patient. Thus, the generation of clinical doses of MSC requires large-scale ex vivo cell expansion and having an optimal scale-up strategy for MSC manufacturing is critical for ensuring product quality while minimizing costs and time of production, as well as avoiding potential risks. The following are some key variables in the cell culture bioprocess to consider when designing MSC therapeutics.

\section{Cell Plating Density}

Cell plating density is a key parameter to ensure adequate expansion rates while maintaining stemness properties (332). The literature suggests that plating densities, both at isolation and subculturing, can influence functional and molecular characteristics of the MSCs $(49,219,333)$, and yet it is something not well-standardized across laboratories. There are contradictory reports regarding the optimal subculturing seeding densities. Generally, higher plating densities (i.e., > 5000 cells $/ \mathrm{cm}^{2}$ ) have resulted in reduced proliferation rates, most likely due to contact inhibition by confluency and the need for continuous premature passaging (332), which is known to critically affect the proliferation rate of MSCs (242, 333-337). Also, the log phase has a longer duration in cells plated at low densities, and therefore more population doublings occur due to a longer exponential growth phase (338). Thus, finding the optimum seeding density for a maximal expansion of therapeutic MSCs while being cost-effective is crucial (339). Some studies have recommended using very low seeding densities when subculturing, as such required for clonal selection (i.e., $<500$ cells $/ \mathrm{cm}^{2}$ ), as it has been shown to result in the highest cell proliferation rates (339-342). Other studies have used slightly higher densities between 2, 000 and 4, 000 cells $/ \mathrm{cm}^{2}(49,206$, 343). The disadvantage of using very low seeding densities (i.e. $<100$ cells $/ \mathrm{cm}^{2}$ ) for a clinical-scale production of MSCs is the large surface area required to culture therapeutic doses of MSCs, which is not feasible when using $175 \mathrm{~cm}^{2}$ flasks, due to the need for large incubator occupancy, a sizable amount of lab reagents and increased handling times. Plating densities of $1,000 \mathrm{cells} / \mathrm{cm}^{2}$ 
have been considered reasonable, as this density still allows for a high number of harvested cells $(243,342,344)$. However, often more cost/labor compromises are undertaken with most current clinical trials using plating densities of over 3,000 cells $/ \mathrm{cm}^{2}(48)$. In the kidney disease clinical trial arena, a mix of low and high plating densities have been reported, ranging from $100 \mathrm{cells} / \mathrm{cm}^{2}$ to 500,000 cells $/ \mathrm{cm}^{2}$ (Table 2 ).

Cell plating densities at the isolation phase have also shown similar outcomes in clinical trials. Sotiropoulou et al., have shown that initial plating density of bone marrow mononuclear cells (BM-MNCs) had a great impact on the size of the MSC-enriched population derived, with the maximum number of adherent cells at P0 obtained when using lower plating densities $(<25$, 000 cells $/ \mathrm{cm}^{2}$ ) compared to high plating densities $(>50,000$ cells $/ \mathrm{cm}^{2}$ ), with 1,000 cells $/ \mathrm{cm}^{2}$ being the optimal condition (341). But similar challenges are encountered here, where large surface areas may be needed for the initial plating. For instance, given that up to $1 \times 10^{8} \mathrm{BM}-\mathrm{MNC}$ are commonly obtained, $\sim 600 \times 175 \mathrm{~cm}^{2}$ would be needed to seed $1 \times 10^{8} \mathrm{BM}-$ MNC at 1,000 cells $/ \mathrm{cm}^{2}$, which is not practical or costefficient. Indeed, the most common seeding densities used in clinical trials are $1.5-1.6 \times 10^{5}$ cells $/ \mathrm{cm}^{2}$, followed by $1 \times 10^{6}$ cells $/ \mathrm{cm}^{2}$ (48). In our search on clinical trials for kidney disease, seeding densities at isolation have been reported to be $1-2 \times$ $10^{5}$ cells $/ \mathrm{cm}^{2}$ (Table 2). One approach to reducing the plating surface area at isolation would be cell enrichment by prospective immunoselection using antibodies directed against specific cell surface markers to obtain a more homogeneous, pure, and welldefined functional subset of MSC subpopulation. For instance, some markers that have been used to purify distinct subsets of MSCs include CD146 (345), CD271 (346, 347), Stro-1 (348) and CD362 (349), which have shown properties such as having greater paracrine immunomodulatory and anti-inflammatory properties $(188,345,349)$, increased osteogenic commitment $(346,347)$, and higher production of cardiovascular-relevant cytokine production (348).

\section{Passage Number}

MSCs are an adherent cell population and have normal growth inhibition when confluent. This has led to the use of successive passages for obtaining a large amount of MSCs. Passage number, which refers to the number of times cells have been sub-cultured, is often recorded as an indicator of cellular age. Cell expansion requires enzyme dissociation and cell subculture, and while the evaluation of the optimal cell confluence may vary among operators, a $70-80 \%$ confluence is recommended to be reached before detachment (323). In general, passage numbers from 1 to 5 are commonly used in clinical trials $(48,324)$ and we have also found similar trends in our search (Table 2). The use of low passage MSCs for therapy is currently preferred to higher passages due to the impact that extended passaging has in decreasing the cell proliferation rates and increasing senescence times (242, 333-337). Long-term culture has also been shown to affect other properties of MSC such as immunosuppressive activity (242, 335), trilineage differentiation (333, 334, 337), in vivo therapeutic potential $(333,337,350)$, and have also been shown to increase genomic instability although not to induce in vivo tumorigenicity $(336,337)$. Also, the advantage of transplanting MSC at earlier passages over late passages was demonstrated clinically in patients with GVHD, where 1-year survival rates were higher in those patients that received MSCs at passages 1-2 (75\%) compared to those that received later passage MSCs (passage 3-4) (350). Effects of passage number in combination with cryopreservation cycles have also been described to impact the safety profile of MSC products, with cells cultured for extended times triggering stronger prothrombotic events compared with cells cultured for shorter times and "fresh" cells $(44,168)$. For these reasons, regulatory agencies have recognized the importance of cellular age tracking during the manufacturing process, as well as the need for karyotypic analysis as a product release criterion. While passage number has been traditionally used for cellular age tracking, this is largely dependent on the specific seeding and harvest density conditions, and therefore it is challenging to make comparisons between studies. Population doubling level (PDL), which refer to the total number of times the cells have doubled during in vitro culture, is, therefore, a more robust and accurate parameter to define cellular aging. An upper limit of PDL, before culture ceases to replicate, must be defined for each product. The literature suggests a maximum number of cell population doubling to be between 15 and 30 (333), although this may be influenced by the cell type (i.e., UC-MSC showed higher proliferation rates and later senescence than AT- and BM-MSCs) $(230,242,243,351)$ and the culture processing characteristics (219).

\section{Media Supplements}

The most common basal media employed in current MSC expansion protocols are DMEM or $\alpha$ MEM (48), although $\alpha$ MEM has shown to be more suitable for both isolation and expansion of MSCs $(341,352)$. MSCs however require media supplements such as serum and/or growth factors to be added to the basal medium for optimal MSC growth. Most expansion protocols, especially at laboratory-scale and in early phase clinical trials, have used fetal calf serum (FCS) with $10 \%$ being the standard concentration used for MSC expansion (48). Basic fibroblast growth factor (b-FGF), at a final concentration of $1-2 \mathrm{ng} / \mathrm{ml}$, is also added to the basal media to enhance the proliferation rate of cultured cells while maintaining the multilineage differentiation potential $(353,354)$. Nevertheless, the use of FCS for largescale production of clinical doses of MSCs is not a viable option (355). Limitations in the availability of the raw material are a major cost driver and represent a current bottleneck. Also, due to the batch-to-batch variability, FCS lots must be carefully tested to ensure optimal MSC expansion rates and trilineage differentiation potential. In addition to this, there are current regulatory challenges associated with the use of FCS to produce clinical-grade MSCs due to the risk of inter-species cross-contamination, and regulators urge the development of xenogeneic-free compositions. Considerations to using humanderived blood components such as human platelet lysate (hPL), often at a final concentration of 5-10\%, have been given $(47,356)$. While hPL has been shown to have comparable growth factors and cytokines to FCS to support MSC growth (355), it poses some important challenges (357). HPL can be derived from autologous 
collections, but it does not represent a good commercial model. Large scale, allogeneic, off-the-shelf pools are easier to standardize, have less lot-to-lot variation, is more economical to produce and therefore represents a better commercial model. Nevertheless, while hPL collections can be obtained from up to 100 different individuals, the size of pools is a current issue and a topic of debate. Recently, regulators have expressed their concern about the increased risk of transmission of infectious agents in large pooled hPL products. The European Pharmacopeia have recommended the limitation of pooled donations unless sufficient methods for inactivation or removal of viruses are applied during the production, although it does not give specific recommendations to the pool size (Chapter 5.2.12). However, representatives of the German Federal Regulatory Authority specified the restriction to a maximum of 16 donors (358). This imposes many challenges for ATMP developers and commercial entities, who must fast adapt their products to the constantly evolving regulatory framework. Overall, a consensus is needed to ensure the quality and safety of hPL supplements regarding the source of platelet concentrate, donor- and lot- variability, manufacturing processes and minimum release criteria (357).

Due to the concerns mentioned above, the development of new xenogeneic-free, chemically defined formulations is urgently needed. Chemically defined media (CDM) are generally composed of basal media to which supplements of known composition (i.e., growth factors, hormones, attachment factors, binding proteins, and vitamins) are added (320). An ideal MSC media should contain chemically defined constituents preferably of recombinant human origin that support the isolation and culture expansion of human MSCs obtained from different tissue sources while maintaining MSC phenotypic characteristics, morphology, and mechanism of functional benefit. Ideally, it should also support the attachment of MSCs without coating. Extensive testing is however required to ensure these media fulfill MSC requirements, but when successful, this type of media will have the potential to enhance batch-to-batch consistency in the cell manufacturing process and will therefore represent a more cost-effective and risk-reduced approach. To date, 10\% FCS continues to be the most common media supplement employed in clinical trials for kidney disease, although some consideration has been given to the use of xenogeneic-free media such as hPL (5 or $10 \%$ ), human serum albumin (HSA) and a CDM (Table 2). Currently, some commercial and non-commercial CDM formulations have been investigated (359-363), however, there is still limited availability of some of these media for large-scale manufacturing at GMP quality level.

\section{Cell Culture Devices}

Currently, a complete closed system that allows MSC acquisition, expansion, and delivery at the bedside, is not yet available. GMP conditions have been mainly achieved using laminar airflow cabinets to perform the main steps in the bioprocess such as culture inception, medium changes, subculturing and packaging. Traditionally, scale-out of MSC manufacturing has been achieved using 2D monolayer cultures using multilayered flasks (Corning ${ }^{\circledR}$ CellSTACK and Nunc ${ }^{\mathrm{TM}}$ Cell Factory ${ }^{\mathrm{TM}}$ ) of 1 to 40 levels, and surfaces ranging from $636 \mathrm{~cm}$ to $25,440 \mathrm{~cm}$.
However, this is not an optimal system for large-scale production of therapeutic doses, as it is labor-intense, requires significant manual handling, and is not cost-effective $(320,364)$. These are also static systems, which lack real-time process monitoring of culture conditions, and are more susceptible to batch-tobatch variation due to a non-homogeneous environment within layers (320). Alternatively, GMP-compliant, closed, automated, high-volume cell expansion systems offer great advantages, as they enable the real-time monitoring of process variables such as $\mathrm{pH}, \mathrm{pO}_{2}, \mathrm{pCO}_{2}$, metabolite accumulation or presence of contaminants, and hence it guarantees a homogeneous distribution of culture environment and ensures a culture process under well-controlled and reproducible conditions and production of quality MSCs for clinical use. A variety of bioreactors are available including stirred tank bioreactors with microcarriers (365, 366), rocking motion (367), disposable fixed bed (368), and hollow fiber-based continuous perfusion bioreactors $(369,370)$. The surface area from these bioreactors ranges from $21,000 \mathrm{~cm}^{2} /$ unit to up to $3,750,000 \mathrm{~cm}^{2} /$ unit, and they all offer distinct advantages and limitations that must be considered $(320,364,371)$. In our search, an overwhelming majority of clinical trials have used 2D culture conditions, with only 1 study considering a 3D bioreactor, the Quantum Cell Expansion System (Terumo BCT) (NEPHSTROM clinical trial, NCT02585622) (Table 2).

\section{CONCLUSIONS AND FUTURE PERSPECTIVES}

While the field of cell-based therapies evolves, the selection of particular MSC types in specific clinical conditions remains to be elucidated. In the past decades, BM has been the preferred source of MSCs used in clinical trials of kidney disease, but recently allogeneic sources have emerged as strong candidates in the clinical research arena. Ideally an allogeneic, "off-the-shelf" MSC product would be preferred, especially for acute kidney disease settings where delivery time is crucial. We hypothesize that, the use of MSCs may be rationalized by the intrinsic origin-specific properties which may make one cell type more advantageous for a specific disease condition. Overall, the high proliferative capacity, the stronger immunosuppressive effects and hypo-immunogenetic properties of UC-MSCs paired with their allogeneic nature makes them ideal to be used in an "offthe-shelf," large-scale, universal production model. Although it is likely that the choice of MSC type may be driven by intellectual and/or industrial property on isolation methods, protocols and/or reagents in addition to issues of functional and biological superiority, considerations should be also given to the safety of this therapies, in particular accounting for differences in immune and hemocompatibility characteristics. Considering this constellation of variables, robust clinical guidelines and well-characterized therapeutic products are urgently needed to deliver safer, effective, and potent MSC therapies to improve clinical outcomes. This will require a greater understanding of the biology of MSCs from different tissue sources along with an alignment with disease pathophysiology coupled with 
consideration and standardization of the cell manufacturing variables reviewed in this article.

\section{AUTHOR CONTRIBUTIONS}

SC-C, CS-N, and TO'B wrote sections of the manuscript. All authors contributed to manuscript revision, read, and approved the submitted version.

\section{REFERENCES}

1. WHO. Global Health Estimates. (2019). Available online at: https://www. who.int/data/global-health-estimates (accessed July 19, 2021).

2. Hill NR, Fatoba ST, Oke JL, Hirst JA, O'Callaghan CA, Lasserson DS, et al. Global prevalence of chronic kidney disease - a systematic review and metaanalysis. PLoS ONE. (2016) 11:e0158765. doi: 10.1371/journal.pone.0158765

3. GBD Chronic Kidney Disease Collaboration: Bikbov B, Purcell CA, Levey AS, Smith M, Abdoli A, Abebe M, et al. Global, regional, and national burden of chronic kidney disease, 1990-2017: a systematic analysis for the Global Burden of Disease Study 2017. Lancet. (2020) 395:709-33. doi: 10.1016/s0140-6736(20)30045-3

4. Kidney Disease: Improving Global Outcomes (KDIGO) CKD Work Group. KDIGO 2012 clinical practice guideline for the evaluation and management of chronic kidney disease. Kidney. (2013) 3:1-150. doi: $10.1038 /$ kisup. 2012.73

5. Khwaja A. KDIGO clinical practice guidelines for acute kidney injury. Nephron Clin Pract. (2012) 120:c179-84. doi: 10.1159/000339789

6. Wang LL, Janes ME, Kumbhojkar N, Kapate N, Clegg JR, Prakash S, et al. Cell therapies in the clinic. Bioeng Transl Med. (2021) 6:e10214. doi: 10.1002/btm2.10214

7. Heathman TR, Nienow AW, McCall MJ, Coopman K, Kara B, Hewitt CJ. The translation of cell-based therapies: clinical landscape and manufacturing challenges. Regen Med. (2015) 10:49-64. doi: 10.2217/rme.14.73

8. Roemhild A, Otto NM, Moll G, Abou-El-Enein M, Kaiser D, Bold $\mathrm{G}$, et al. Regulatory $\mathrm{T}$ cells for minimising immune suppression in kidney transplantation: phase I/IIa clinical trial. BMJ. (2020) 371:m3734. doi: $10.1136 /$ bmj.m3734

9. Sawitzki B, Harden PN, Reinke P, Moreau A, Hutchinson JA, Game DS, et al. Regulatory cell therapy in kidney transplantation (The ONE Study): a harmonised design and analysis of seven non-randomised, single-arm, phase 1/2A trials. Lancet Lond Engl. (2020) 395:1627-39. doi: 10.1016/s0140-6736(20)30167-7

10. Griffin TP, Martin WP, Islam N, O'Brien T, Griffin MD. The promise of mesenchymal stem cell therapy for diabetic kidney disease. Curr Diabetes Rep. (2016) 16:42. doi: 10.1007/s11892-016-0734-6

11. Zhu X, Lerman A, Lerman LO. Concise review: mesenchymal stem cell treatment for ischemic kidney disease. Stem Cells. (2013) 31:1731-6. doi: $10.1002 /$ stem. 1449

12. Morigi M, Imberti B, Zoja C, Corna D, Tomasoni S, Abbate M, et al. Mesenchymal stem cells are renotropic, helping to repair the kidney and improve function in acute renal failure. J Am Soc Nephrol. (2004) 15:1794804. doi: 10.1097/01.asn.0000128974.07460.34

13. Papazova DA, Oosterhuis NR, Gremmels H, Koppen A van, Joles JA, Verhaar MC. Cell-based therapies for experimental chronic kidney disease: a systematic review and meta-analysis. Dis Model Mech. (2015) 8:281-93. doi: 10.1242/dmm.017699

14. Gooch A, Doty J, Flores J, Swenson L, Töegel FE, Reiss GR, et al. Initial report on a phase I clinical trial: prevention and treatment of postoperative Acute Kidney Injury with allogeneic Mesenchymal Stem Cells in patients who require on-pump ca. Cell Therap Transpl. (2008) 1:31-5. doi: 10.3205/ctt-2008-en-000028.01

15. Tögel FE, Westenfelder C. Mesenchymal stem cells: a new therapeutic tool for AKI. Nat Rev Nephrol. (2010) 6:179-83. doi: 10.1038/nrneph.2009.229

\section{FUNDING}

This work was supported by grants from SFI CÚRAM Research Center (Grant No. 13/RC/2073), Science Foundation Ireland (SFI) (Grant No. 18/IF/6252) and from the European Union's Horizon 2020 research and innovation programme under the Marie Skłodowska-Curie Grant Agreement No. 813839.

16. Tögel FE, Westenfelder C. Kidney protection and regeneration following acute injury: progress through stem cell therapy. Am J Kidney Dis. (2012) 60:1012-22. doi: 10.1053/j.ajkd.2012.08.034

17. Westenfelder C, Togel FE. Protective actions of administered mesenchymal stem cells in acute kidney injury: relevance to clinical trials. Kidney Int Suppl. (2011) 1:103-6. doi: 10.1038/kisup. 2011.24

18. Swaminathan M, Stafford-Smith M, Chertow GM, Warnock DG, Paragamian V, Brenner RM, et al. Allogeneic mesenchymal stem cells for treatment of AKI after cardiac surgery. J Am Soc Nephrol. (2018) 29:260-7. doi: 10.1681/asn.2016101150

19. Perico N, Casiraghi F, Remuzzi G. Clinical translation of mesenchymal stromal cell therapies in nephrology. J Am Soc Nephrol. (2018) 29:362-75. doi: 10.1681/asn.2017070781

20. McIntyre LA, Stewart DJ, Mei SHJ, Courtman D, Watpool I, Granton J, et al. Cellular immunotherapy for septic shock. A phase I clinical trial. Am J Resp Crit Care. (2018) 197:337-47. doi: 10.1164/rccm.201705-1006oc

21. Makhlough A, Shekarchian S, Moghadasali R, Einollahi B, Hosseini SE, Jaroughi $\mathrm{N}$, et al. Safety and tolerability of autologous bone marrow mesenchymal stromal cells in ADPKD patients. Stem Cell Res Ther. (2017) 8:116. doi: 10.1186/s13287-017-0557-7

22. Saad A, Dietz AB, Herrmann SMS, Hickson LJ, Glockner JF, McKusick $\mathrm{MA}$, et al. Autologous mesenchymal stem cells increase cortical perfusion in renovascular disease. J Am Soc Nephrol. (2017) 28:2777-85. doi: 10.1681 /asn.2017020151

23. Packham DK, Fraser IR, Kerr PG, Segal KR. Allogeneic Mesenchymal Precursor Cells (MPC) in diabetic nephropathy: a randomized, placebocontrolled, dose escalation study. Ebiomedicine. (2016) 12:263-9. doi: 10.1016/j.ebiom.2016.09.011

24. Liang J, Zhang H, Hua B, Wang H, Lu L, Shi S, et al. Allogenic mesenchymal stem cells transplantation in refractory systemic lupus erythematosus: a pilot clinical study. Ann Rheum Dis. (2010) 69:1423. doi: 10.1136/ard.2009.123463

25. Sun L, Wang D, Liang J, Zhang $H$, Feng $X$, Wang $H$, et al. Umbilical cord mesenchymal stem cell transplantation in severe and refractory systemic lupus erythematosus. Arthritis Rheum. (2010) 62:2467-5. doi: 10.1002/art.27548

26. Wang D, Zhang H, Liang J, Li X, Feng X, Wang H, et al. Allogeneic mesenchymal stem cell transplantation in severe and refractory systemic lupus erythematosus: 4 years of experience. Cell Transplant. (2012) 22:226777. doi: $10.3727 / 096368911 \times 582769 \mathrm{c}$

27. Wang D, Li J, Zhang Y, Zhang M, Chen J, Li X, et al. Umbilical cord mesenchymal stem cell transplantation in active and refractory systemic lupus erythematosus: a multicenter clinical study. Arthritis Res Ther. (2014) 16:R79. doi: $10.1186 /$ ar4520

28. Deng D, Zhang P, Guo Y, Lim TO. A randomised double-blind, placebocontrolled trial of allogeneic umbilical cord-derived mesenchymal stem cell for lupus nephritis. Ann Rheum Dis. (2017) 76:1436. doi: 10.1136/annrheumdis-2017-211073

29. Choi CB, Lee TY, Kim KS, Bae SC. AB0370 Safety of CS20AT04, a haploidentical allogeneic bone marrow-derived mesenchymal stem cells, in a phase 1 study in lupus nephritis. Ann Rheum Dis. (2020) 79:1485. doi: 10.1136/annrheumdis-2020-eular.3287

30. Tan J, Wu W, Xu X, Liao L, Zheng F, Messinger S, et al. Induction therapy with autologous mesenchymal stem cells in living-related kidney 
transplants: a randomized controlled trial. JAMA. (2012) 307:1169-77. doi: 10.1001/jama.2012.316

31. Reinders MEJ, Fijter JW de, Roelofs H, Bajema IM, Vries DK de, Schaapherder AF, et al. Autologous bone marrow-derived mesenchymal stromal cells for the treatment of allograft rejection after renal transplantation: results of a Phase I Study. Stem Cell Transl Med. (2013) 2:107-11. doi: 10.5966/sctm.2012-0114

32. Perico N, Casiraghi F, Introna M, Gotti E, Todeschini M, Cavinato RA, et al. Autologous mesenchymal stromal cells and kidney transplantation: a pilot study of safety and clinical feasibility. Clin J Am Soc Nephro. (2011) 6:412-2. doi: 10.2215/cjn. 04950610

33. Perico N, Casiraghi F, Gotti E, Introna M, Todeschini M, Cavinato RA, et al. Mesenchymal stromal cells and kidney transplantation: pretransplant infusion protects from graft dysfunction while fostering immunoregulation. Transplant Int. (2013) 26:867-78. doi: 10.1111/tri.12132

34. Perico N, Casiraghi F, Todeschini M, Cortinovis M, Gotti E, Portalupi V, et al. Long-term clinical and immunological profile of kidney transplant patients given mesenchymal stromal cell immunotherapy. Front Immunol. (2018) 9:1359. doi: 10.3389/fimmu.2018.01359

35. Peng Y, Ke M, Xu L, Liu L, Chen X, Xia W, et al. Donor-derived mesenchymal stem cells combined with low-dose tacrolimus prevent acute rejection after renal transplantation. Transplant J. (2013) 95:161-8. doi: $10.1097 /$ tp.0b013e3182754c53

36. Sun Q, Huang Z, Han F, Zhao M, Cao R, Zhao D, et al. Allogeneic mesenchymal stem cells as induction therapy are safe and feasible in renal allografts: pilot results of a multicenter randomized controlled trial. J Transl Med. (2018) 16:52. doi: 10.1186/s12967-018-1422-x

37. Sun Q, Hong L, Huang Z, Na N, Hua X, Peng Y, et al. Allogeneic mesenchymal stem cell as induction therapy to prevent both delayed graft function and acute rejection in deceased donor renal transplantation: study protocol for a randomized controlled trial. Trials. (2017) 18:545. doi: 10.1186/s13063-017-2291-y

38. Mudrabettu C, Kumar V, Rakha A, Yadav AK, Ramachandran R, Kanwar DB, et al. Safety and efficacy of autologous mesenchymal stromal cells transplantation in patients undergoing living donor kidney transplantation: a pilot study. Nephrology. (2015) 20:25-33. doi: 10.1111/nep.12338

39. Rakha A, Todeschini M, Casiraghi F. Assessment of anti-donor T cell proliferation and cytotoxic T lymphocyte-mediated lympholysis in living donor kidney transplant patients. Methods Mol Biol. (2014) 1213:355-64. doi: 10.1007/978-1-4939-1453-1_29

40. Reinders MEJ, Dreyer GJ, Bank JR, Roelofs H, Heidt S, Roelen DL, et al. Safety of allogeneic bone marrow derived mesenchymal stromal cell therapy in renal transplant recipients: the Neptune study. J Transl Med. (2015) 13:344. doi: 10.1186/s12967-015-0700-0

41. Reinders ME, Bank JR, Dreyer GJ, Roelofs H, Heidt S, Roelen DL, et al. Autologous bone marrow derived mesenchymal stromal cell therapy in combination with Everolimus to preserve renal structure and function in renal transplant recipients. J Transl Med. (2014) 12:331. doi: 10.1186/s12967-014-0331-x

42. Detry O, Delbouille M-H, Lechanteur C, Somja J, Roover AD, Weekers L, et al. Infusion of Third-party Mesenchymal stem Cells (MSC) after kidney and liver transplantation: a phase I-II, open-label, clinical study. Soc Francophone Transpl. (2013). Available online at: http://hdl.handle.net/2268/152646

43. Sanz-Nogués C, O'Brien T. Current good manufacturing practice considerations for mesenchymal stromal cells as therapeutic agents. Biomaterials Biosyst. (2021) 2:100018. doi: 10.1016/j.bbiosy.2021. 100018

44. Moll G, Ankrum JA, Kamhieh-Milz J, Bieback K, Ringdén O, Volk H$D$, et al. Intravascular mesenchymal stromal/stem cell therapy product diversification: time for new clinical guidelines. Trends Mol Med. (2019) 25:149-63. doi: 10.1016/j.molmed.2018.12.006

45. Caplan H, Olson SD, Kumar A, George M, Prabhakara KS, Wenzel $\mathrm{P}$, et al. Mesenchymal stromal cell therapeutic delivery: translational challenges to clinical application. Front Immunol. (2019) 10:1645. doi: 10.3389 /fimmu.2019.01645

46. Yin JQ, Zhu J, Ankrum JA. Manufacturing of primed mesenchymal stromal cells for therapy. Nat Biomed Eng. (2019) 3:90-104. doi: $10.1038 / \mathrm{s} 41551-018-0325-8$
47. Trento C, Bernardo ME, Nagler A, Kuçi S, Bornhäuser M, Köhl U, et al. Manufacturing mesenchymal stromal cells for the treatment of graft-versushost disease: a survey among centers affiliated with the European society for blood and marrow transplantation. Biol Blood Marrow Treat. (2018) 24:2365-70. doi: 10.1016/j.bbmt.2018.07.015

48. Ikebe C, Suzuki K. Mesenchymal stem cells for regenerative therapy: optimization of cell preparation protocols. Biomed Res Int. (2014) 2014:951512. doi: 10.1155/2014/951512

49. Stroncek DF, Jin P, McKenna DH, Takanashi M, Fontaine MJ, Pati S, et al. Human Mesenchymal Stromal Cell (MSC) characteristics vary among laboratories when manufactured from the same source material: a report by the cellular therapy team of the Biomedical Excellence for Safer Transfusion (BEST) collaborative. Front Cell Dev Biol. (2020) 8:458. doi: $10.3389 /$ fcell.2020.00458

50. Liu M, Lei H, Dong P, Fu X, Yang Z, Yang Y, et al. Adipose-derived mesenchymal stem cells from the elderly exhibit decreased migration and differentiation abilities with senescent properties. Cell Transplant. (2017) 26:1505-19. doi: 10.1177/0963689717721221

51. Choudhery MS, Badowski M, Muise A, Pierce J, Harris DT. Donor age negatively impacts adipose tissue-derived mesenchymal stem cell expansion and differentiation. J Transl Med. (2014) 12:8. doi: 10.1186/1479-5876-12-8

52. Crisostomo PR, Markel TA, Wang M, Lahm T, Lillemoe KD, Meldrum DR. In the adult mesenchymal stem cell population, source gender is a biologically relevant aspect of protective power. Surgery. (2007) 142:215-21. doi: 10.1016/j.surg.2007.04.013

53. Siegel G, Kluba T, Hermanutz-Klein U, Bieback K, Northoff H, Schäfer R. Phenotype, donor age and gender affect function of human bone marrow-derived mesenchymal stromal cells. BMC Med. (2013) 11:146. doi: 10.1186/1741-7015-11-146

54. Andrzejewska A, Catar R, Schoon J, Qazi TH, Sass FA, Jacobi D, et al. Multi-parameter analysis of biobanked human bone marrow stromal cells shows little influence for donor age and mild comorbidities on phenotypic and functional properties. Front Immunol. (2019) 10:2474. doi: $10.3389 /$ fimmu. 2019.02474

55. Lalu MM, McIntyre L, Pugliese C, Fergusson D, Winston BW, Marshall JC, et al. Safety of Cell Therapy with Mesenchymal Stromal Cells (SafeCell): a systematic review and meta-analysis of clinical trials. PLoS ONE. (2012) 7:e47559. doi: 10.1371/journal.pone.0047559

56. Kot M, Baj-Krzyworzeka M, Szatanek R, Musiał-Wysocka A, Suda-Szczurek M, Majka M. The Importance of HLA Assessment in "Off-the-Shelf" allogeneic mesenchymal stem cells based-therapies. Int J Mol Sci. (2019) 20:5680. doi: $10.3390 /$ ijms 20225680

57. Friedenstein AJ, Chailakhjan RK, Lalykina KS. The development of fibroblast colonies in monolayer cultures of guinea-pig bone marrow and spleen cells. Cell Proliferat. (1970) 3:393-403. doi: 10.1111/j.1365-2184.1970.tb00347.x

58. Friedenstein AJ, Petrakova KV, Kurolesova AI, Frolova GP. Heterotopic transplants of bone marrow. Transplantation. (1968) 6:230-47. doi: 10.1097/00007890-196803000-00009

59. Pittenger MF, Mackay AM, Beck SC, Jaiswal RK, Douglas R, Mosca JD, et al. Multilineage potential of adult human mesenchymal stem cells. Science. (1999) 284:143-7. doi: 10.1126/science.284.5411.143

60. Prockop DJ. Marrow stromal cells as stem cells for nonhematopoietic tissues. Science. (1997) 276:71-4. doi: 10.1126/science.276. 5309.71

61. Murray IR, West CC, Hardy WR, James AW, Park TS, Nguyen A, et al. Natural history of mesenchymal stem cells, from vessel walls to culture vessels. Cell Mol Life Sci. (2013) 71:1353-74. doi: 10.1007/s00018-0131462-6

62. Mosna F, Sensebé L, Krampera M. Human bone marrow and adipose tissue mesenchymal stem cells: a user's guide. Stem Cells Dev. (2010) 19:1449-70. doi: 10.1089/scd.2010.0140

63. Crisan M, Yap S, Casteilla L, Chen C-W, Corselli M, Park TS, et al. A perivascular origin for mesenchymal stem cells in multiple human organs. Cell Stem Cell. (2008) 3:301-13. doi: 10.1016/j.stem.2008. 07.003

64. Bianco P. "Mesenchymal" stem cells. Annu Rev Cell Dev Bi. (2014) 30:677-704. doi: 10.1146/annurev-cellbio-100913013132 
65. Zuk PA, Zhu M, Mizuno H, Huang J, Futrell JW, Katz AJ, et al. Multilineage cells from human adipose tissue: implications for cell-based therapies. Tissue Eng. (2001) 7:211-28. doi: 10.1089/107632701300062859

66. Gronthos S, Brahim J, Li W, Fisher LW, Cherman N, Boyde A, et al. Stem cell properties of human dental pulp stem cells. J Dent Res. (2002) 81:531-5. doi: $10.1177 / 154405910208100806$

67. Huang GT-J, Gronthos S, Shi S. Mesenchymal stem cells derived from dental tissues vs. those from other sources: their biology and role in regenerative medicine. J Dent Res. (2009) 88:792-806. doi: 10.1177/0022034509340867

68. Schüring AN, Schulte N, Kelsch R, Röpke A, Kiesel L, Götte M. Characterization of endometrial mesenchymal stem-like cells obtained by endometrial biopsy during routine diagnostics. Fertil Steril. (2011) 95:423-6. doi: 10.1016/j.fertnstert.2010.08.035

69. Meng X, Ichim TE, Zhong J, Rogers A, Yin Z, Jackson J, et al. Endometrial regenerative cells: a novel stem cell population. J Transl Med. (2007) 5:57. doi: 10.1186/1479-5876-5-57

70. Allickson JG. Recent studies assessing the proliferative capability of a novel adult stem cell identified in menstrual blood. Open Stem Cell J. (2011) 3:4-10. doi: 10.2174/1876893801103010004

71. Zvaifler NJ, Marinova-Mutafchieva L, Adams G, Edwards CJ, Moss J, Burger JA, et al. Mesenchymal precursor cells in the blood of normal individuals. Arthritis Res Ther. (2000) 2:477. doi: 10.1186/ar130

72. Kadir RA, Ariffin SHZ, Wahab RMA, Kermani S, Senafi S. Characterization of mononucleated human peripheral blood cells. Sci World J. (2012) 2012:843843. doi: 10.1100/2012/843843

73. Erices A, Conget P, Minguell JJ. Mesenchymal progenitor cells in human umbilical cord blood. Brit J Haematol. (2000) 109:235-42. doi: 10.1046/j.1365-2141.2000.01986.x

74. Anker PS in 't, Scherjon SA, Keur CK der, Noort WA, Claas FHJ, Willemze R, et al. Amniotic fluid as a novel source of mesenchymal stem cells for therapeutic transplantation. Blood. (2003) 102:1548-9. doi: 10.1182/blood-2003-04-1291

75. Wang H-S, Hung S-C, Peng S-T, Huang C-C, Wei H-M, Guo Y-J, et al. Mesenchymal stem cells in the Wharton's Jelly of the Human Umbilical Cord. Stem Cells. (2004) 22:1330-7. doi: 10.1634/stemcells.2004-0013

76. Miao Z, Jin J, Chen L, Zhu J, Huang W, Zhao J, et al. Isolation of mesenchymal stem cells from human placenta: comparison with human bone marrow mesenchymal stem cells. Cell Biol Int. (2006) 30:681-7. doi: 10.1016/j.cellbi.2006.03.009

77. Kim J, Kang HM, Kim H, Kim MR, Kwon HC, Gye MC, et al. Ex vivo characteristics of human amniotic membrane-derived stem cells. Cloning Stem Cells. (2007) 9:581-94. doi: 10.1089/clo.2007.0027

78. Tsai M, Lee J, Chang Y, Hwang S. Isolation of human multipotent mesenchymal stem cells from second-trimester amniotic fluid using a novel two-stage culture protocol. Hum Reprod. (2004) 19:1450-6. doi: 10.1093/humrep/deh279

79. Tögel F, Hu Z, Weiss K, Isaac J, Lange C, Westenfelder C. Administered mesenchymal stem cells protect against ischemic acute renal failure through differentiation-independent mechanisms. Am J Physiol. (2005) 289:F31-42. doi: 10.1152/ajprenal.00007.2005

80. Crespo-Diaz R, Behfar A, Butler GW, Padley DJ, Sarr MG, Bartunek J, et al. Platelet lysate consisting of a natural repair proteome supports human mesenchymal stem cell proliferation and chromosomal stability. Cell Transplant. (2011) 20:797-812. doi: 10.3727/096368910x543376

81. Detry O, Vandermeulen M, Delbouille M-H, Somja J, Bletard N, Briquet A, et al. Infusion of mesenchymal stromal cells after deceased liver transplantation: a phase I-II, open-label, clinical study. J Hepatol. (2017) 67:47-55. doi: 10.1016/j.jhep.2017.03.001

82. Ferenbach DA, Bonventre JV. Acute kidney injury and chronic kidney disease: from the laboratory to the clinic. Néphrol Thérap. (2016) 12:S41-8. doi: 10.1016/j.nephro.2016.02.005

83. Ishani A, Xue JL, Himmelfarb J, Eggers PW, Kimmel PL, Molitoris BA, et al. Acute kidney injury increases risk of ESRD among elderly. J Am Soc Nephrol. (2009) 20:223-8. doi: 10.1681/asn.2007080837

84. Levey AS, James MT. Acute kidney injury. Ann Intern Med. (2017) 167:ITC66. doi: 10.7326/aitc201711070

85. Bellomo R, Kellum JA, Ronco C. Acute kidney injury. Lancet. (2012) 380:756-66. doi: 10.1016/s0140-6736(11)61454-2
86. Wasung ME, Chawla LS, Madero M. Biomarkers of renal function, which and when? Clin Chim Acta. (2015) 438:350-7. doi: 10.1016/j.cca.2014.08.039

87. Miller RP, Tadagavadi RK, Ramesh G, Reeves WB. Mechanisms of cisplatin nephrotoxicity. Toxins. (2010) 2:2490-518. doi: 10.3390/toxins 2112490

88. Kosieradzki M, Rowiński W. Ischemia/reperfusion injury in kidney transplantation: mechanisms and prevention. Transplant Prevt. (2008) 40:3279-88. doi: 10.1016/j.transproceed.2008.10.004

89. Malek $M$, Nematbakhsh $M$. Renal ischemia/reperfusion injury; from pathophysiology to treatment. J Ren Inj Prev. (2015) 4:20-7. doi: 10.12861/jrip.2015.06

90. Ferenbach DA, Bonventre JV. Mechanisms of maladaptive repair after AKI leading to accelerated kidney ageing and CKD. Nat Rev Nephrol. (2015) 11:264-76. doi: 10.1038/nrneph.2015.3

91. Lange C, Tögel F, Ittrich H, Clayton F, Nolte-Ernsting C, Zander AR, et al. Administered mesenchymal stem cells enhance recovery from ischemia/reperfusion-induced acute renal failure in rats. Kidney Int. (2005) 68:1613-7. doi: 10.1111/j.1523-1755.2005.00573.x

92. Geng Y, Zhang L, Fu B, Zhang J, Hong Q, Hu J, et al. Mesenchymal stem cells ameliorate rhabdomyolysis-induced acute kidney injury via the activation of M2 macrophages. Stem Cell Res Ther. (2014) 5:80. doi: 10.1186/scrt469

93. Collino F, Bruno S, Incarnato D, Dettori D, Neri F, Provero P, et al. AKI recovery induced by mesenchymal stromal cell-derived extracellular vesicles carrying MicroRNAs. J Am Soc Nephrol. (2015) 26:2349-60. doi: 10.1681/asn.2014070710

94. Bi B, Schmitt R, Israilova M, Nishio H, Cantley LG. Stromal cells protect against acute tubular injury via an endocrine effect. J Am Soc Nephrol. (2007) 18:2486-96. doi: 10.1681/asn.2007020140

95. Li L, Wang R, Jia Y, Rong R, Xu M, Zhu T. Exosomes derived from mesenchymal stem cells ameliorate renal ischemic-reperfusion injury through inhibiting inflammation and cell apoptosis. Front Med. (2019) 6:269. doi: $10.3389 / \mathrm{fmed} .2019 .00269$

96. He J, Wang Y, Sun S, Yu M, Wang C, Pei X, et al. Bone marrow stem cells-derived microvesicles protect against renal injury in the mouse remnant kidney model. Nephrology. (2012) 17:493-500. doi: 10.1111/j.1440-1797.2012.01589.x

97. Yasuda K, Ozaki T, Saka Y, Yamamoto T, Gotoh M, Ito Y, et al. Autologous cell therapy for cisplatin-induced acute kidney injury by using nonexpanded adipose tissue-derived cells. Cytotherapy. (2012) 14:1089-100. doi: 10.3109/14653249.2012.693157

98. Chen Y, Tang X, Li P, Zhou Y, Xue T, Liu J, et al. Bone marrow derived mesenchymal stromal cells ameliorate ischemia/reperfusion injury-induced acute kidney injury in rats via secreting tumor necrosis factor-inducible gene 6 protein. Biomed Res Int. (2019) 2019:1-12. doi: 10.1155/2019/9845709

99. Zhu G, Pei L, Lin F, Yin H, Li X, He W, et al. Exosomes from human-bone-marrow-derived mesenchymal stem cells protect against renal ischemia/reperfusion injury via transferring miR-199a-3p. J Cell Physiol. (2019) 234:23736-49. doi: 10.1002/jcp.28941

100. Chen Y-T, Sun C-K, Lin Y-C, Chang L-T, Chen Y-L, Tsai T-H, et al. Adipose-derived mesenchymal stem cell protects kidneys against ischemiareperfusion injury through suppressing oxidative stress and inflammatory reaction. J Transl Med. (2011) 9:51. doi: 10.1186/1479-5876-9-51

101. Zhuo W, Liao L, Xu T, Wu W, Yang S, Tan J. Mesenchymal stem cells ameliorate ischemia-reperfusion-induced renal dysfunction by improving the antioxidant/oxidant balance in the ischemic kidney. Urol Int. (2011) 86:191-6. doi: 10.1159/000319366

102. Zhang G, Zou X, Huang Y, Wang F, Miao S, Liu G, et al. Mesenchymal stromal cell-derived extracellular vesicles protect against acute kidney injury through anti-oxidation by enhancing Nrf2/ARE activation in rats. Kidney Blood Press Res. (2016) 41:119-28. doi: 10.1159/000443413

103. Moll G, Jitschin R, Bahr L von, Rasmusson-Duprez I, Sundberg B, Lönnies $\mathrm{L}$, et al. Mesenchymal stromal cells engage complement and complement receptor bearing innate effector cells to modulate immune responses. PLoS ONE. (2011) 6:e21703. doi: 10.1371/journal.pone.0021703

104. Zilberman-Itskovich S, Abu-Hamad R, Zarura R, Sova M, Hachmo Y, Stark M, et al. Human mesenchymal stromal cells ameliorate complement induced inflammatory cascade and improve renal functions in a rat model of ischemia-reperfusion induced acute kidney injury. PLoS ONE. (2019) 14:e222354. doi: 10.1371/journal.pone.0222354 
105. Tang M, Zhang K, Li Y, He Q, Li G, Zheng Q, et al. Mesenchymal stem cells alleviate acute kidney injury by down-regulating C5a/C5aR pathway activation. Int Urol Nephrol. (2018) 50:1545-53. doi: 10.1007/s11255-018-1844-7

106. Zhou L, Xu L, Shen J, Song Q, Wu R, Ge Y, et al. Preischemic administration of nonexpanded adipose stromal vascular fraction attenuates acute renal ischemia/reperfusion injury and fibrosis. Stem Cell Transl Med. (2016) 5:1277-88. doi: 10.5966/sctm.2015-0223

107. Zhou L, Song Q, Shen J, Xu L, Xu Z, Wu R, et al. Comparison of human adipose stromal vascular fraction and adipose-derived mesenchymal stem cells for the attenuation of acute renal ischemia/reperfusion injury. Sci Rep. (2017) 7:44058. doi: 10.1038/srep44058

108. Zou X, Zhang G, Cheng Z, Yin D, Du T, Ju G, et al. Microvesicles derived from human Wharton's Jelly mesenchymal stromal cells ameliorate renal ischemia-reperfusion injury in rats by suppressing CX3CL1. Stem Cell Res Ther. (2014) 5:40. doi: 10.1186/scrt428

109. Feng Z, Ting J, Alfonso Z, Strem BM, Fraser JK, Rutenberg J, et al. Fresh and cryopreserved, uncultured adipose tissue-derived stem and regenerative cells ameliorate ischemia-reperfusion-induced acute kidney injury. Nephrol Dial Transpl. (2010) 25:3874-84. doi: 10.1093/ndt/gfq603

110. Collett JA, Traktuev DO, Mehrotra P, Crone A, Merfeld-Clauss S, March KL, et al. Human adipose stromal cell therapy improves survival and reduces renal inflammation and capillary rarefaction in acute kidney injury. J Cell Mol Med. (2017) 21:1420-30. doi: 10.1111/jcmm.13071

111. Tsuda H, Yamahara K, Otani K, Okumi M, Yazawa K, Kaimori J, et al. Transplantation of allogenic fetal membrane-derived mesenchymal stem cells protects against ischemia/reperfusion-induced acute kidney injury. Cell Transpl. (2014) 23:889-99. doi: 10.3727/096368913x665594

112. Liu X, Cai J, Jiao X, Yu X, Ding X. Therapeutic potential of mesenchymal stem cells in acute kidney injury is affected by administration timing. Acta Bioch Bioph Sin. (2017) 49:338-48. doi: 10.1093/abbs/gmx016

113. Jia X, Pan J, Li X, Li N, Han Y, Feng X, et al. Bone marrow mesenchymal stromal cells ameliorate angiogenesis and renal damage via promoting PI3kAkt signaling pathway activation in vivo. Cytotherapy. (2016) 18:838-45. doi: 10.1016/j.jcyt.2016.03.300

114. Tögel $\mathrm{F}$, Zhang $\mathrm{P}, \mathrm{Hu} \mathrm{Z}$, Westenfelder C. VEGF is a mediator of the renoprotective effects of multipotent marrow stromal cells in acute kidney injury. J Cell Mol Med. (2008) 13:2109-14. doi: 10.1111/j.1582-4934.2008.00641.x

115. Tögel F, Cohen A, Zhang P, Yang Y, Hu Z, Westenfelder C. Autologous and allogeneic marrow stromal cells are safe and effective for the treatment of acute kidney injury. Stem Cells Dev. (2009) 18:475-85. doi: $10.1089 /$ scd.2008.0092

116. Zou X, Gu D, Xing X, Cheng Z, Gong D, Zhang G, et al. Human mesenchymal stromal cell-derived extracellular vesicles alleviate renal ischemic reperfusion injury and enhance angiogenesis in rats. Am J Transl Res. (2016) 8:4289-99.

117. Lindoso RS, Collino F, Bruno S, Araujo DS, Sant'Anna JF, Tetta C, et al. Extracellular vesicles released from mesenchymal stromal cells modulate miRNA in renal tubular cells and inhibit ATP depletion injury. Stem Cells Dev. (2014) 23:1809-19. doi: 10.1089/scd.2013.0618

118. Perico L, Morigi M, Rota C, Breno M, Mele C, Noris M, et al. Human mesenchymal stromal cells transplanted into mice stimulate renal tubular cells and enhance mitochondrial function. Nat Commun. (2017) 8:983. doi: 10.1038/s41467-017-00937-2

119. Gu D, Zou X, Ju G, Zhang G, Bao E, Zhu Y. Mesenchymal stromal cells derived extracellular vesicles ameliorate acute renal ischemia reperfusion injury by inhibition of mitochondrial fission through miR-30. Stem Cells Int. (2016) 2016:1-12. doi: 10.1155/2016/2093940

120. Zhang F, Wan X, Cao Y, Sun D, Cao C. Klotho gene-modified BMSCs showed elevated antifibrotic effects by inhibiting the Wnt $/ \beta$-catenin pathway in kidneys after acute injury. Cell Biol Int. (2018) 42:1670-79. doi: $10.1002 /$ cbin. 11068

121. Damasceno PKF, Santana TA de, Santos GC, Orge ID, Silva DN, Albuquerque JF, et al. Genetic engineering as a strategy to improve the therapeutic efficacy of mesenchymal stem/stromal cells in regenerative medicine. Front Cell Dev Biol. (2020) 8:737. doi: 10.3389/fcell.2020. 00737
122. Liu Y, Fang J. Mesenchymal stem cells as therapeutic agents and novel carriers for the delivery of candidate genes in acute kidney injury. Stem Cells Int. (2020) 2020:8875554. doi: 10.1155/2020/8875554

123. Jang MJ, You D, Park JY, Kim K, Aum J, Lee C, et al. Hypoxic preconditioned mesenchymal stromal cell therapy in a rat model of renal ischemia-reperfusion injury: development of optimal protocol to potentiate therapeutic efficacy. Int J Stem Cells. (2018) 11:157-67. doi: $10.15283 / \mathrm{ijsc1} 8073$

124. Zhang W, Liu L, Huo Y, Yang Y, Wang Y. Hypoxia-pretreated human MSCs attenuate acute kidney injury through enhanced angiogenic and antioxidative capacities. Biomed Res Int. (2014) 2014:1-10. doi: 10.1155/2014/462472

125. Collino F, Lopes JA, Corrêa S, Abdelhay E, Takiya CM, Wendt $\mathrm{CHC}$, et al. Adipose-derived mesenchymal stromal cells under hypoxia: changes in extracellular vesicles secretion and improvement of renal recovery after ischemic injury. Cell Physiol Biochem. (2019) 52:1463-83. doi: 10.33594/000000102

126. Noronha N de C, Mizukami A, Caliári-Oliveira C, Cominal JG, Rocha JLM, Covas DT, et al. Priming approaches to improve the efficacy of mesenchymal stromal cell-based therapies. Stem Cell Res Ther. (2019) 10:131. doi: 10.1186/s13287-019-1224-y

127. Miceli V, Bulati M, Iannolo G, Zito G, Gallo A, Conaldi PG. Therapeutic properties of mesenchymal stromal/stem cells: the need of cell priming for cell-free therapies in regenerative medicine. Int J Mol Sci. (2021) 22:763. doi: 10.3390/ijms 22020763

128. Kanai R, Nakashima A, Doi S, Kimura T, Yoshida K, Maeda S, et al. Interferon- $\gamma$ enhances the therapeutic effect of mesenchymal stem cells on experimental renal fibrosis. Sci Rep. (2021) 11:850. doi: 10.1038/s41598-020-79664-6

129. Gao L, Zhong X, Jin J, Li J, Meng X. Potential targeted therapy and diagnosis based on novel insight into growth factors, receptors, and downstream effectors in acute kidney injury and acute kidney injurychronic kidney disease progression. Signal Transduct Target Ther. (2020) 5:9. doi: 10.1038/s41392-020-0106-1

130. Chawla LS, Kimmel PL. Acute kidney injury and chronic kidney disease: an integrated clinical syndrome. Kidney Int. (2012) 82:516-524. doi: 10.1038/ki.2012.208

131. Leung KCW, Tonelli M, James MT. Chronic kidney disease following acute kidney injury-risk and outcomes. Nat Rev Nephrol. (2012) 9:77-85. doi: 10.1038/nrneph.2012.280

132. Kiriakidou M, Ching CL. Systemic Lupus Erythematosus. Ann Intern Med. (2020) 172:ITC81-ITC96. doi: 10.7326/aitc202006020

133. D’Agati VD, Kaskel FJ, Falk RJ. Focal Segmental Glomerulosclerosis. New Engl J Medicine. (2011) 365:2398-411. doi: 10.1056/nejmra1106556

134. Heung M, Chawla LS. Acute kidney injury: gateway to chronic kidney disease. Nephron Clin Pract. (2014) 127:30-4. doi: 10.1159/000363675

135. Zeisberg M, Neilson EG. Mechanisms of tubulointerstitial fibrosis. J Am Soc Nephrol. (2010) 21:1819-34. doi: 10.1681/asn.2010080793

136. Gatti S, Bruno S, Deregibus MC, Sordi A, Cantaluppi V, Tetta C, et al. Microvesicles derived from human adult mesenchymal stem cells protect against ischaemia-reperfusion-induced acute and chronic kidney injury. Nephrol Dial Transpl. (2011) 26:1474-83. doi: 10.1093/ndt/gfr015

137. Sun D, Bu L, Liu C, Yin Z, Zhou X, Li X, et al. Therapeutic effects of human amniotic fluid-derived stem cells on renal interstitial fibrosis in a murine model of unilateral ureteral obstruction. PLoS ONE. (2013) 8:e65042. doi: 10.1371/journal.pone.0065042

138. Donizetti-Oliveira C, Semedo P, Burgos-Silva M, Cenedeze MA, Malheiros DMAC, Reis MA, et al. Adipose tissue-derived stem cell treatment prevents renal disease progression. Cell Transpl. (2012) 21:1727-41. doi: 10.3727/096368911x623925

139. Zhu F, Shin OLSCL, Pei G, Hu Z, Yang J, Zhu H, et al. Adiposederived mesenchymal stem cells employed exosomes to attenuate AKICKD transition through tubular epithelial cell dependent Sox 9 activation. Oncotarget. (2017) 8:70707-26. doi: 10.18632/oncotarget.19979

140. Wang B, Yao K, Huuskes BM, Shen H-H, Zhuang J, Godson C, et al. Mesenchymal stem cells deliver exogenous MicroRNA-let7c via exosomes to attenuate renal fibrosis. Mol Ther. (2016) 24:1290-301. doi: $10.1038 / \mathrm{mt} .2016 .90$ 
141. Semedo P, Correa-Costa M, Cenedeze MA, Malheiros DMAC, Reis MA dos, Shimizu MH, et al. Mesenchymal stem cells attenuate renal fibrosis through immune modulation and remodeling properties in a rat remnant kidney model. Stem Cells. (2009) 27:214. doi: 10.1002/stem.214

142. Koppen A van, Joles JA, Bongartz LG, Brandt J van den, Reichardt HM, Goldschmeding R, et al. Healthy bone marrow cells reduce progression of kidney failure better than CKD bone marrow cells in rats with established chronic kidney disease. Cell Transplant. (2012) 21:2299-312. doi: $10.3727 / 096368912 \times 636795$

143. Rivera-Valdés JJ, García-Bañuelos J, Salazar-Montes A, García-Benavides L, Rosales-Dominguez A, Armendáriz-Borunda J, et al. Human adipose derived stem cells regress fibrosis in a chronic renal fibrotic model induced by adenine. PLoS ONE. (2017) 12:e0187907. doi: 10.1371/journal.pone.0187907

144. Jang E, Jeong M, Kim S, Jang K, Kang B-K, Lee DY, et al. Infusion of human bone marrow-derived mesenchymal stem cells alleviates autoimmune nephritis in a lupus model by suppressing follicular helper T-cell development. Cell Transplant. (2015) 25:1-15. doi: $10.3727 / 096368915 \times 688173$

145. Yuan X, Qin X, Wang D, Zhang Z, Tang X, Gao X, et al. Mesenchymal stem cell therapy induces FLT3L and CD1c+ dendritic cells in systemic lupus erythematosus patients. Nat Commun. (2019) 10:2498. doi: 10.1038/s41467-019-10491-8

146. Zhou T, Liao C, Li H-Y, Lin W, Lin S, Zhong H. Efficacy of mesenchymal stem cells in animal models of lupus nephritis: a meta-analysis. Stem Cell Res Ther. (2020) 11:48. doi: 10.1186/s13287-019-1538-9

147. Nagaishi K, Mizue Y, Chikenji T, Otani M, Nakano M, Konari N, et al. Mesenchymal stem cell therapy ameliorates diabetic nephropathy via the paracrine effect of renal trophic factors including exosomes. Sci Rep-uk. (2016) 6:34842. doi: 10.1038/srep34842

148. Fang Y, Tian X, Bai S, Fan J, Hou W, Tong H, et al. Autologous transplantation of adipose-derived mesenchymal stem cells ameliorates streptozotocin-induced diabetic nephropathy in rats by inhibiting oxidative stress, pro-inflammatory cytokines and the p38 MAPK signaling pathway. Int J Mol Med. (2012) 30:85-92. doi: 10.3892/ijmm.2012.977

149. Lv S, Liu G, Sun A, Wang J, Cheng J, Wang W, et al. Mesenchymal stem cells ameliorate diabetic glomerular fibrosis in vivo and in vitro by inhibiting TGF$\beta$ signalling via secretion of bone morphogenetic protein 7. Diabetes Vasc Dis Res. (2014) 11:251-61. doi: 10.1177/1479164114531300

150. Konari N, Nagaishi K, Kikuchi S, Fujimiya M. Mitochondria transfer from mesenchymal stem cells structurally and functionally repairs renal proximal tubular epithelial cells in diabetic nephropathy in vivo. Sci Rep. (2019) 9:5184. doi: 10.1038/s41598-019-40163-y

151. Ge W, Jiang J, Arp J, Liu W, Garcia B, Wang H. Regulatory T-cell generation and kidney allograft tolerance induced by mesenchymal stem cells associated with indoleamine 2,3-dioxygenase expression. Transplantation. (2010) 90:1312-20. doi: 10.1097/tp.0b013e3181fed001

152. Bai M, Zhang L, Fu B, Bai J, Zhang Y, Cai G, et al. IL-17A improves the efficacy of mesenchymal stem cells in ischemic-reperfusion renal injury by increasing Treg percentages by the COX-2/PGE2 pathway. Kidney Int. (2018) 93:814-25. doi: 10.1016/j.kint.2017.08.030

153. Casiraghi F, Todeschini M, Azzollini N, Cravedi P, Cassis P, Solini S, et al. Effect of timing and complement receptor antagonism on intragraft recruitment and pro-tolerogenic effects of mesenchymal stromal cells in murine kidney transplantation. Transplantation. (2019) 103:1121-30. doi: 10.1097/tp.0000000000002611

154. Casiraghi F, Azzollini N, Todeschini M, Cavinato RA, Cassis P, Solini S, et al. Localization of mesenchymal stromal cells dictates their immune or proinflammatory effects in kidney transplantation. Am J Transplant. (2012) 12:2373-83. doi: 10.1111/j.1600-6143.2012.04115.x

155. Sivanathan KN, Rojas-Canales DM, Hope CM, Krishnan R, Carroll RP, Gronthos S, et al. Interleukin-17A-induced human mesenchymal stem cells are superior modulators of immunological function. Stem Cells. (2015) 33:2850-63. doi: 10.1002/stem.2075

156. Franquesa M, Herrero E, Torras J, Ripoll E, Flaquer M, Gomà M, et al. Mesenchymal stem cell therapy prevents interstitial fibrosis and tubular atrophy in a rat kidney allograft model. Stem Cells Dev. (2012) 21:3125-35. doi: $10.1089 / \mathrm{scd} .2012 .0096$
157. Martino MD, Zonta S, Rampino T, Gregorini M, Frassoni F, Piotti $\mathrm{G}$, et al. Mesenchymal stem cells infusion prevents acute cellular rejection in rat kidney transplantation. Transplant Prev. (2010) 42:1331-5. doi: 10.1016/j.transproceed.2010.03.079

158. Lee S-R, Lee S-H, Moon J-Y, Park J-Y, Lee D, Lim SJ, et al. Repeated administration of bone marrow-derived mesenchymal stem cells improved the protective effects on a remnant kidney model. Renal Failure. (2010) 32:840-8. doi: 10.3109/0886022x.2010.494803

159. Cai J, Jiao X, Zhao S, Liang Y, Ning Y, Shi Y, et al. Transforming growth factor- $\beta 1$-overexpressing mesenchymal stromal cells induced local tolerance in rat renal ischemia/reperfusion injury. Cytotherapy. (2019) 21:535-45. doi: 10.1016/j.jcyt.2018.12.003

160. Cao Z, Zhang G, Wang F, Liu H, Liu L, Han Y, et al. Protective effects of mesenchymal stem cells with CXCR4 up-regulation in a rat renal transplantation model. PLoS ONE. (2013) 8:e82949. doi: 10.1371/journal.pone.0082949

161. Gregorini M, Bosio F, Rocca C, Corradetti V, Valsania T, Pattonieri EF, et al. Mesenchymal stromal cells reset the scatter factor system and cytokine network in experimental kidney transplantation. BMC Immunol. (2014) 15:44. doi: 10.1186/s12865-014-0044-1

162. Zonta S, Martino MD, Bedino G, Piotti G, Rampino T, Gregorini M, et al. Which is the most suitable and effective route of administration for mesenchymal stem cell-based immunomodulation therapy in experimental kidney transplantation: endovenous or arterial? Transplant Prev. (2010) 42:1336-40. doi: 10.1016/j.transproceed.2010.03.081

163. Ramirez-Bajo MJ, Rovira J, Lazo-Rodriguez M, Banon-Maneus E, Tubita $\mathrm{V}$, Moya-Rull D, et al. Impact of mesenchymal stromal cells and their extracellular vesicles in a rat model of kidney rejection. Front Cell Dev Biol. (2020) 8:10. doi: 10.3389/fcell.2020.00010

164. Koch M, Lehnhardt A, Hu X, Brunswig-Spickenheier B, Stolk M, Bröcker $\mathrm{V}$, et al. Isogeneic MSC application in a rat model of acute renal allograft rejection modulates immune response but does not prolong allograft survival. Transpl Immunol. (2013) 29:43-50. doi: 10.1016/j.trim.2013.08.004

165. Mendicino M, Bailey AM, Wonnacott K, Puri RK, Bauer SR. MSC-based product characterization for clinical trials: an FDA perspective. Cell Stem Cell. (2014) 14:141-5. doi: 10.1016/j.stem.2014.01.013

166. Eggenhofer E, Benseler V, Kroemer A, Popp FC, Geissler EK, Schlitt $\mathrm{HJ}$, et al. Mesenchymal stem cells are short-lived and do not migrate beyond the lungs after intravenous infusion. Front Immunol. (2012) 3:297. doi: 10.3389/fimmu.2012.00297

167. Fischer UM, Harting MT, Jimenez F, Monzon-Posadas WO, Xue H, Savitz SI, et al. Pulmonary passage is a major obstacle for intravenous stem cell delivery: the pulmonary first-pass effect. Stem Cells Dev. (2009) 18:683-92. doi: $10.1089 / \mathrm{scd} .2008 .0253$

168. Moll G, Rasmusson-Duprez I, Bahr L von, Connolly-Andersen A, Elgue G, Funke L, et al. Are therapeutic human mesenchymal stromal cells compatible with human blood? Stem Cells. (2012) 30:1565-74. doi: 10.1002/stem.1111

169. Gleeson BM, Martin K, Ali MT, Kumar AHS, Pillai MG-K, Kumar SPG, et al. Bone marrow-derived mesenchymal stem cells have innate procoagulant activity and cause microvascular obstruction following intracoronary delivery: amelioration by antithrombin therapy. Stem Cells Dayt Ohio. (2015) 33:2726-37. doi: 10.1002/stem.2050

170. Christy BA, Herzig MC, Montgomery RK, Delavan C, Bynum JA, Reddoch KM, et al. Procoagulant activity of human mesenchymal stem cells. J Trauma Acute Care. (2017) 83:S164-9. doi: 10.1097/ta.0000000000001485

171. Bamoulid J, Staeck O, Halleck F, Khadzhynov D, Brakemeier $S$, Dürr $M$, et al. The need for minimization strategies: current problems of immunosuppression. Transplant Int. (2015) 28:891-900. doi: $10.1111 /$ tri. 12553

172. Berglund AK, Fortier LA, Antczak DF, Schnabel LV. Immunoprivileged no more: measuring the immunogenicity of allogeneic adult mesenchymal stem cells. Stem Cell Res Ther. (2017) 8:288. doi: 10.1186/s13287-017-0742-8

173. Torre RS la, Quiñones-Vico MI, Fernández-González A, Sánchez-Díaz M, Montero-Vílchez T, Sierra-Sánchez Á, et al. Alloreactive immune response associated to human mesenchymal stromal cells treatment: a systematic review. J Clin Medicine. (2021) 10:2991. doi: 10.3390/ jcm10132991 
174. Ankrum JA, Ong JF, Karp JM. Mesenchymal stem cells: immune evasive, not immune privileged. Nat Biotechnol. (2014) 32:252-60. doi: 10.1038/nbt.2816

175. Lohan P, Treacy O, Griffin MD, Ritter T, Ryan AE. Anti-donor immune responses elicited by allogeneic mesenchymal stem cells and their extracellular vesicles: are we still learning? Front Immunol. (2017) 8:1626. doi: 10.3389/fimmu.2017.01626

176. Hoogduijn MJ, Lombardo E. Mesenchymal stromal cells anno 2019: dawn of the therapeutic era? Concise Review. Stem Cell Transl Med. (2019) 8:112634. doi: 10.1002/sctm.19-0073

177. Chabot D, Lewin A, Loubaki L, Bazin R. Functional impairment of MSC induced by transient warming events: correlation with loss of adhesion and altered cell size. Cytotherapy. (2018) 20:990-1000. doi: 10.1016/j.jcyt.2018.05.010

178. Moll G, Alm JJ, Davies LC, Bahr L von, Heldring N, Stenbeck-Funke L, et al. Do cryopreserved mesenchymal stromal cells display impaired immunomodulatory and therapeutic properties? Stem Cells. (2014) 32:243042. doi: 10.1002/stem. 1729

179. François M, Copland IB, Yuan S, Romieu-Mourez R, Waller EK, Galipeau J. Cryopreserved mesenchymal stromal cells display impaired immunosuppressive properties as a result of heat-shock response and impaired interferon- $\gamma$ licensing. Cytotherapy. (2011) 14:147-52. doi: 10.3109/14653249.2011.623691

180. Chinnadurai R, Copland IB, Garcia MA, Petersen CT, Lewis CN, Waller EK, et al. Cryopreserved mesenchymal stromal cells are susceptible to tcell mediated apoptosis which is partly rescued by IFN $\gamma$ licensing: thawed MSCs are susceptible to T cell mediated lysis. Stem Cells. (2016) 34:2429-42. doi: $10.1002 /$ stem.2415

181. Hoogduijn MJ, Witte SFH de, Luk F, Vroonhoven MCGN van den H, Ignatowicz L, Catar R, et al. Effects of freeze-thawing and intravenous infusion on mesenchymal stromal cell gene expression. Stem Cells Dev. (2016) 25:586-97. doi: 10.1089/scd.2015.0329

182. Gramlich OW, Burand AJ, Brown AJ, Deutsch RJ, Kuehn MH, Ankrum JA. Cryopreserved mesenchymal stromal cells maintain potency in a retinal ischemia/reperfusion injury model: toward an off-the-shelf therapy. Sci Rep. (2016) 6:26463. doi: 10.1038/srep26463

183. Luetzkendorf J, Nerger K, Hering J, Moegel A, Hoffmann K, Hoefers C, et al. Cryopreservation does not alter main characteristics of Good Manufacturing Process-grade human multipotent mesenchymal stromal cells including immunomodulating potential and lack of malignant transformation. Cytotherapy. (2015) 17:186-98. doi: 10.1016/j.jcyt.2014.10.018

184. Galipeau J, Krampera M, Leblanc K, Nolta JA, Phinney DG, Shi Y, et al. Mesenchymal stromal cell variables influencing clinical potency: the impact of viability, fitness, route of administration and host predisposition. Cytotherapy. (2021) 23:368-72. doi: 10.1016/j.jcyt.2020.11.007

185. Yuan X, Logan TM, Ma T. Metabolism in human mesenchymal stromal cells: a missing link between hMSC biomanufacturing and therapy? Front Immunol. (2019) 10:977. doi: 10.3389/fimmu.2019.00977

186. Oja S, Kaartinen T, Ahti M, Korhonen M, Laitinen A, Nystedt J. The Utilization of freezing steps in Mesenchymal Stromal Cell (MSC) manufacturing: potential impact on quality and cell functionality attributes. Front Immunol. (2019) 10:1627. doi: 10.3389/fimmu.2019.01627

187. Galleu A, Riffo-Vasquez Y, Trento C, Lomas C, Dolcetti L, Cheung TS, et al. Apoptosis in mesenchymal stromal cells induces in vivo recipient-mediated immunomodulation. Sci Transl Med. (2017) 9:eaam7828. doi: 10.1126/scitranslmed.aam7828

188. Witte SFH, Luk F, Parraga JMS, Gargesha M, Merino A, Korevaar SS, et al. Immunomodulation by Therapeutic Mesenchymal Stromal Cells (MSC) is triggered through phagocytosis of MSC by monocytic cells. Stem Cells. (2018) 36:602-15. doi: 10.1002/stem.2779

189. Weiss DJ, English K, Krasnodembskaya A, Isaza-Correa JM, Hawthorne IJ, Mahon BP. The necrobiology of mesenchymal stromal cells affects therapeutic efficacy. Front Immunol. (2019) 10:1228. doi: $10.3389 /$ fimmu. 2019.01228

190. Moll G, Geißler S, Catar R, Ignatowicz L, Hoogduijn MJ, Strunk D, Bieback K, Ringdén O. Cryopreserved or Fresh Mesenchymal Stromal Cells: Only a Matter of Taste or Key to Unleash the Full Clinical Potential of MSC Therapy? Adv Exp Med Biol. (2016) 951:77-98. doi: 10.1007/978-3-319-45457-3_7
191. Third Party Mesenchymal Stromal Cell Infusion in Kidney Transplant Recipient: 6-Month Safety Interim Analysis - ATC Abstracts. Available online at: https://atcmeetingabstracts.com/abstract/third-party-mesenchymalstromal-cell-infusion-in-kidney-transplant-recipient-6-month-safetyinterim-analysis/ (accessed May 7, 2021).

192. Assfalg V, Hüser N, Meel M van, Haller B, Rahmel A, Boer J de, et al. High-urgency kidney transplantation in the Eurotransplant Kidney Allocation System: success or waste of organs? The Eurotransplant 15-year all-centre survey. Nephrol Dial Transpl. (2016) 31:1515-22. doi: 10.1093/ndt/ gfv 446

193. Summers DM, Johnson RJ, Allen J, Fuggle SV, Collett D, Watson CJ, et al. Analysis of factors that affect outcome after transplantation of kidneys donated after cardiac death in the UK: a cohort study. Lancet. (2010) 376:1303-11. doi: 10.1016/s0140-6736(10) 60827-6

194. Snoeijs MGJ, Winkens B, Heemskerk MBA, Hoitsma AJ, Christiaans MHL, Buurman WA, Heurn LWE. Kidney transplantation from donors after cardiac death; a 25-year experience. Transplantation. (2010) 90:1106-12. doi: $10.1097 /$ tp.0b013e3181f83b0b

195. Casiraghi F, Remuzzi G. Mesenchymal stromal cells in kidney transplantation. Curr Opin Nephrol Hyg. (2019) 28:40-6. doi: $10.1097 / \mathrm{mnh} .0000000000000461$

196. Peerapornratana S, Manrique-Caballero CL, Gómez H, Kellum JA. Acute kidney injury from sepsis: current concepts, epidemiology, pathophysiology, prevention and treatment. Kidney Int. (2019) 96:1083-99. doi: 10.1016/j.kint.2019.05.026

197. Liu Y, Cui J, Wang H, Hezam K, Zhao X, Huang H, et al. Enhanced therapeutic effects of MSC-derived extracellular vesicles with an injectable collagen matrix for experimental acute kidney injury treatment. Stem Cell Res Ther. (2020) 11:161. doi: 10.1186/s13287-020-01668-w

198. Miller BLK, Garg P, Bronstein B, LaPointe E, Lin H, Charytan DM, et al. Extracorporeal stromal cell therapy for subjects with dialysisdependent acute kidney injury. Kidney Int Rep. (2018) 3:1119-27. doi: 10.1016/j.ekir.2018.05.009

199. Ko K-W, Park S-Y, Lee EH, Yoo Y-I, Kim D-S, Kim JY, et al. Integrated bioactive scaffold with polydeoxyribonucleotide and stem-cell-derived extracellular vesicles for kidney regeneration. Acs Nano. (2021) 15:7575-85. doi: 10.1021/acsnano.1c01098

200. Malhotra R, Siew ED. Biomarkers for the early detection and prognosis of acute kidney injury. Clin J Am Soc Nephro. (2017) 12:149-73. doi: $10.2215 / \mathrm{cjn} .01300216$

201. Textor SC, Lerman LO. Paradigm shifts in atherosclerotic renovascular disease: where are we now? J Am Soc Nephrol Jasn. (2015) 26:2074-80. doi: 10.1681/asn.2014121274

202. Chade AR, Rodriguez-Porcel M, Grande JP, Krier JD, Lerman A, Romero JC, et al. Distinct renal injury in early atherosclerosis and renovascular disease. Circulation. (2002) 106:1165-71. doi: 10.1161/01.cir.0000027105.02327.48

203. Nassar W, El-Ansary M, Sabry D, Mostafa MA, Fayad T, Kotb E, et al. Umbilical cord mesenchymal stem cells derived extracellular vesicles can safely ameliorate the progression of chronic kidney diseases. Biomater Res. (2016) 20:21. doi: 10.1186/s40824-016-0068-0

204. Rani S, Ryan AE, Griffin MD, Ritter T. Mesenchymal stem cell-derived extracellular vesicles: toward cell-free therapeutic applications. Mol Ther. (2015) 23:812-23. doi: 10.1038/mt.2015.44

205. Rhijn MR, Reinders MEJ, Klein A de, Douben H, Korevaar SS, Mensah FKF, et al. Mesenchymal stem cells derived from adipose tissue are not affected by renal disease. Kidney Int. (2012) 82:748-58. doi: 10.1038/ki.2012.187

206. Reinders MEJ, Rhijn MR, Khairoun M, Lievers E, Vries DK de, Schaapherder AFM, et al. Bone marrow-derived mesenchymal stromal cells from patients with end-stage renal disease are suitable for autologous therapy. Cytotherapy. (2013) 15:663-72. doi: 10.1016/j.jcyt.2013.01.010

207. Rhijn-Brouwer FCC van, Balkom BWM van, Papazova DA, Hazenbrink DHM, Meijer AJ, Brete I, et al. Paracrine proangiogenic function of human bone marrow-derived mesenchymal stem cells is not affected by chronic kidney disease. Stem Cells Int. (2019) 2019:1-12. doi: 10.1155/2019/1232810

208. Tuttle KR, Bakris GL, Bilous RW, Chiang JL, Boer IH de, Goldstein-Fuchs J, et al. Diabetic kidney disease: a report from an ADA consensus conference. Am J Kidney Dis. (2014) 64:510-33. doi: 10.1053/j.ajkd.2014.08.001 
209. Skyler JS, Fonseca VA, Segal KR, Rosenstock J, Investigators M-D. Allogeneic mesenchymal precursor cells in type 2 diabetes: a randomized, placebocontrolled, dose-escalation safety and tolerability pilot study. Diabetes Care. (2015) 38:1742-9. doi: 10.2337/dc14-2830

210. Mahmoud M, Abu-Shahba N, Azmy O, El-Badri N. Impact of diabetes mellitus on human mesenchymal stromal cell biology and functionality: implications for autologous transplantation. Stem Cell Rev Rep. (2019) 15:194-217. doi: 10.1007/s12015-018-9869-y

211. Cassidy FC, Shortiss C, Murphy CG, Kearns SR, Curtin W, Buitléir CD, et al. Impact of type 2 diabetes mellitus on human bone marrow stromal cell number and phenotypic characteristics. Int J Mol Sci. (2020) 21:2476. doi: $10.3390 /$ ijms 21072476

212. Yu F, Haas M, Glassock R, Zhao M-H. Redefining lupus nephritis: clinical implications of pathophysiologic subtypes. Nat Rev Nephrol. (2017) 13:48395. doi: 10.1038/nrneph.2017.85

213. Cheng R-J, Xiong A-J, Li Y-H, Pan S-Y, Zhang Q-P, Zhao Y, et al. Mesenchymal stem cells: allogeneic MSC may be immunosuppressive but autologous MSC are dysfunctional in lupus patients. Front Cell Dev Biol. (2019) 7:285. doi: 10.3389/fcell.2019.00285

214. Wang D, Wang S, Huang S, Zhang Z, Yuan X, Feng X, et al. Serum IFN$\gamma$ predicts the therapeutic effect of mesenchymal stem cells transplantation in systemic lupus erythematosus patients. Stem Cell Transl Med. (2017) 6:1777-85. doi: 10.1002/sctm.17-0002

215. Wang $\mathrm{D}$, Akiyama $\mathrm{K}$, Zhang $\mathrm{H}$, Yamaza $\mathrm{T}$, Li $\mathrm{X}$, Feng $\mathrm{X}$, et al. Double allogenic mesenchymal stem cells transplantations could not enhance therapeutic effect compared with single transplantation in systemic lupus erythematosus. Clin Dev Immunol. (2012) 2012:273291. doi: 10.1155/2012/273291

216. Wegmeyer H, Bröske A-M, Leddin M, Kuentzer K, Nisslbeck AK, Hupfeld $\mathrm{J}$, et al. Mesenchymal stromal cell characteristics vary depending on their origin. Stem Cells Dev. (2013) 22:2606-18. doi: 10.1089/scd.2013.0016

217. Kern S, Eichler H, Stoeve J, Klüter H, Bieback K. Comparative analysis of mesenchymal stem cells from bone marrow, umbilical cord blood, or adipose tissue. Stem Cells. (2006) 24:1294-301. doi: 10.1634/stemcells.2005-0342

218. Moll G, Ignatowicz L, Catar R, Luecht C, Sadeghi B, Hamad O, et al. Different procoagulant activity of therapeutic mesenchymal stromal cells derived from bone marrow and placental decidua. Stem Cells Dev. (2015) 24:2269-79. doi: 10.1089/scd.2015.0120

219. Winkel A, Jaimes Y, Melzer C, Dillschneider P, Hartwig H, Stiesch M, et al. Cell culture media notably influence properties of human mesenchymal stroma/stem-like cells from different tissues. Cytotherapy. (2020) 22:653-68. doi: 10.1016/j.jcyt.2020.07.005

220. Khan RS, Newsome PN. A comparison of phenotypic and functional properties of mesenchymal stromal cells and multipotent adult progenitor cells. Front Immunol. (2019) 10:1952. doi: 10.3389/fimmu.2019.01952

221. Stenderup K, Justesen J, Clausen C, Kassem M. Aging is associated with decreased maximal life span and accelerated senescence of bone marrow stromal cells. Bone. (2003) 33:919-26. doi: 10.1016/j.bone.2003.07.005

222. Greenberg SB, Grove GL, Cristofalo VJ. Cell size in aging monolayer cultures. Vitro. (1977) 13:297-300. doi: 10.1007/bf02616174

223. Kim M, Bae YK, Um S, Kwon JH, Kim G-H, Choi SJ, et al. A smallsized population of human umbilical cord blood-derived mesenchymal stem cells shows high stemness properties and therapeutic benefit. Stem Cells Int. (2020) 2020:1-17. doi: 10.1155/2020/5924983

224. Bruder SP, Jaiswal N, Haynesworth SE. Growth kinetics, selfrenewal, and the osteogenic potential of purified human mesenchymal stem cells during extensive subcultivation and following cryopreservation. J Cell Biochem. (1997) 64:278-94. doi: 10.1002/(sici) 1097-4644(199702)64:2<278::aid-jcb11>3.0.co;2-f

225. Wagner $\mathrm{W}$, Ho $\mathrm{AD}$, Zenke M. Different facets of aging in human mesenchymal stem cells. Tissue Eng Part B Rev. (2010) 16:445-53. doi: $10.1089 /$ ten.teb.2009.0825

226. Fernandez-Rebollo E, Franzen J, Goetzke R, Hollmann J, Ostrowska A, Oliverio $\mathrm{M}$, et al. Senescence-associated metabolomic phenotype in primary and iPSC-derived mesenchymal stromal cells. Stem Cell Rep. (2020) 14:2019. doi: 10.1016/j.stemcr.2019.12.012

227. Heathman TRJ, Rafiq QA, Chan AKC, Coopman K, Nienow AW, Kara B, et al. Characterization of human mesenchymal stem cells from multiple donors and the implications for large scale bioprocess development. Biochem Eng J. (2016) 108:14-23. doi: 10.1016/j.bej.2015.06.018

228. Bara JJ, Richards RG, Alini M, Stoddart MJ. Concise review: Bone marrowderived mesenchymal stem cells change phenotype following in vitro culture: implications for basic research and the clinic. Stem Cells Dayt Ohio. (2014) 32:1713-23. doi: 10.1002/stem.1649

229. Redaelli S, Bentivegna A, Foudah D, Miloso M, Redondo J, Riva G, et al. From cytogenomic to epigenomic profiles: monitoring the biologic behavior of in vitro cultured human bone marrow mesenchymal stem cells. Stem Cell Res Ther. (2012) 3:47. doi: 10.1186/scrt138

230. Petrenko Y, Vackova I, Kekulova K, Chudickova M, Koci Z, Turnovcova $\mathrm{K}$, et al. A comparative analysis of multipotent mesenchymal stromal cells derived from different sources, with a focus on neuroregenerative potential. Sci Rep. (2020) 10:4290. doi: 10.1038/s41598-02061167-z

231. Hass R, Kasper C, Böhm S, Jacobs R. Different populations and sources of human mesenchymal stem cells (MSC): a comparison of adult and neonatal tissue-derived MSC. Cell Commun Signal. (2011) 9:12. doi: $10.1186 / 1478-811 x-9-12$

232. Dmitrieva RI, Minullina IR, Bilibina AA, Tarasova OV, Anisimov SV, Zaritskey AY. Bone marrow- and subcutaneous adipose tissue-derived mesenchymal stem cells: differences and similarities. Cell Cycle Georget Tex. (2012) 11:377-83. doi: 10.4161/cc.11.2.18858

233. Burrow KL, Hoyland JA, Richardson SM. Human adipose-derived stem cells exhibit enhanced proliferative capacity and retain multipotency longer than donor-matched bone marrow mesenchymal stem cells during expansion in vitro. Stem Cells Int. (2017) 2017:1-15. doi: 10.1155/2017/2541275

234. Mohamed-Ahmed S, Fristad I, Lie SA, Suliman S, Mustafa K, Vindenes $\mathrm{H}$, et al. Adipose-derived and bone marrow mesenchymal stem cells: a donor-matched comparison. Stem Cell Res Ther. (2018) 9:168. doi: 10.1186/s13287-018-0914-1

235. Mohamed SA, Howard L, McInerney V, Hayat A, Krawczyk J, Naughton $S$, et al. Autologous bone marrow mesenchymal stromal cell therapy for "no-option" critical limb ischemia is limited by karyotype abnormalities. Cytotherapy. (2020) 22:313-21. doi: 10.1016/j.jcyt.2020.02.007

236. Bieback K, Kern S, Kocaömer A, Ferlik K, Bugert P. Comparing mesenchymal stromal cells from different human tissues: bone marrow, adipose tissue and umbilical cord blood. Bio-med Mater Eng. (2008) 18:S716.

237. Baksh D, Yao R, Tuan RS. Comparison of proliferative and multilineage differentiation potential of human mesenchymal stem cells derived from umbilical cord and bone marrow. Stem Cells. (2007) 25:1384-92. doi: 10.1634/stemcells.2006-0709

238. Barlow S, Brooke G, Chatterjee K, Price G, Pelekanos R, Rossetti $\mathrm{T}$, et al. Comparison of human placenta- and bone marrow-derived multipotent mesenchymal stem cells. Stem Cells Dev. (2008) 17:1095-108. doi: $10.1089 / \mathrm{scd} .2007 .0154$

239. Choudhery MS, Badowski M, Muise A, Harris DT. Comparison of human mesenchymal stem cells derived from adipose and cord tissue. Cytotherapy. (2013) 15:330-43. doi: 10.1016/j.jcyt.2012.11.010

240. Amable PR, Teixeira MVT, Carias RBV, Granjeiro JM, Borojevic R. Protein synthesis and secretion in human mesenchymal cells derived from bone marrow, adipose tissue and Wharton's jelly. Stem Cell Res Ther. (2014) 5:53. doi: $10.1186 /$ scrt442

241. Heo JS, Choi Y, Kim H-S, Kim HO. Comparison of molecular profiles of human mesenchymal stem cells derived from bone marrow, umbilical cord blood, placenta and adipose tissue. Int J Mol Med. (2016) 37:115-25. doi: $10.3892 / \mathrm{ijmm} .2015 .2413$

242. Witte SFH de, Lambert EE, Merino A, Strini T, Douben HJCW, O'Flynn L, et al. Aging of bone marrow- and umbilical cord-derived mesenchymal stromal cells during expansion. Cytotherapy. (2017) 19:798807. doi: 10.1016/j.jcyt.2017.03.071

243. Li X, Bai J, Ji X, Li R, Xuan Y, Wang Y. Comprehensive characterization of four different populations of human mesenchymal stem cells as regards their immune properties, proliferation and differentiation. Int J Mol Med. (2014) 34:695-704. doi: 10.3892/ijmm.2014.1821

244. Jin H, Bae Y, Kim M, Kwon S-J, Jeon H, Choi S, et al. Comparative analysis of human mesenchymal stem cells from bone marrow, adipose 
tissue, and umbilical cord blood as sources of cell therapy. Int J Mol Sci. (2013) 14:17986-8001. doi: 10.3390/ijms140917986

245. Batsali AK, Pontikoglou C, Koutroulakis D, Pavlaki KI, Damianaki A, Mavroudi I, et al. Differential expression of cell cycle and WNT pathwayrelated genes accounts for differences in the growth and differentiation potential of Wharton's jelly and bone marrow-derived mesenchymal stem cells. Stem Cell Res Ther. (2017) 8:102. doi: 10.1186/s13287-017-0555-9

246. Kehl D, Generali M, Mallone A, Heller M, Uldry A-C, Cheng P, et al. Proteomic analysis of human mesenchymal stromal cell secretomes: a systematic comparison of the angiogenic potential. Npj Regen Medicine. (2019) 4:8. doi: 10.1038/s41536-019-0070-y

247. Pietilä M, Palomäki S, Lehtonen S, Ritamo I, Valmu L, Nystedt J, et al. Mitochondrial function and energy metabolism in umbilical cord bloodand bone marrow-derived mesenchymal stem cells. Stem Cells Dev. (2011) 21:575-88. doi: 10.1089/scd.2011.0023

248. Facchin F, Bianconi E, Romano M, Impellizzeri A, Alviano F, Maioli M, et al. Comparison of oxidative stress effects on senescence patterning of human adult and perinatal tissue-derived stem cells in short and long-term cultures. Int J Med Sci. (2018) 15:1486-501. doi: 10.7150/ijms.27181

249. Zhou W, Lin J, Zhao K, Jin K, He Q, Hu Y, et al. Single-cell profiles and clinically useful properties of human mesenchymal stem cells of adipose and bone marrow origin. Am J Sports Med. (2019) 47:1722-33. doi: $10.1177 / 0363546519848678$

250. Burnham AJ, Foppiani EM, Horwitz EM. Key metabolic pathways in MSC-mediated immunomodulation: implications for the prophylaxis and treatment of graft versus host disease. Front Immunol. (2020) 11:609277. doi: 10.3389/fimmu.2020.609277

251. Li C, Wu X, Tong J, Yang X, Zhao J, Zheng Q, et al. Comparative analysis of human mesenchymal stem cells from bone marrow and adipose tissue under xeno-free conditions for cell therapy. Stem Cell Res Ther. (2015) 6:55. doi: 10.1186/s13287-015-0066-5

252. Menard C, Pacelli L, Bassi G, Dulong J, Bifari F, Bezier I, et al. Clinical-grade mesenchymal stromal cells produced under various good manufacturing practice processes differ in their immunomodulatory properties: standardization of immune quality controls. Stem Cells Dev. (2013) 22:1789-801. doi: 10.1089/scd.2012.0594

253. Dominici M, Blanc KL, Mueller I, Slaper-Cortenbach I, Marini FC, Krause DS, et al. Minimal criteria for defining multipotent mesenchymal stromal cells. The International Society for Cellular Therapy position statement. Cytotherapy. (2006) 8:315-7. doi: 10.1080/14653240600855905

254. Reinisch A, Etchart N, Thomas D, Hofmann NA, Fruehwirth M, Sinha S, et al. Epigenetic and in vivo comparison of diverse MSC sources reveals an endochondral signature for human hematopoietic niche formation. Blood. (2015) 125:249-60. doi: 10.1182/blood-2014-04-572255

255. Xu L, Liu Y, Sun Y, Wang B, Xiong Y, Lin W, et al. Tissue source determines the differentiation potentials of mesenchymal stem cells: a comparative study of human mesenchymal stem cells from bone marrow and adipose tissue. Stem Cell Res Ther. (2017) 8:275. doi: 10.1186/s13287-017-0716-x

256. Wu M, Zhang R, Zou Q, Chen Y, Zhou M, Li X, et al. Comparison of the biological characteristics of mesenchymal stem cells derived from the human placenta and umbilical cord. Sci Rep. (2018) 8:5014. doi: 10.1038/s41598-018-23396-1

257. Zhang X, Hirai M, Cantero S, Ciubotariu R, Dobrila L, Hirsh A, et al. Isolation and characterization of mesenchymal stem cells from human umbilical cord blood: Reevaluation of critical factors for successful isolation and high ability to proliferate and differentiate to chondrocytes as compared to mesenchymal stem cells from bone marrow and adipose tissue. J Cell Biochem. (2011) 112:1206-18. doi: 10.1002/jcb.23042

258. Karagianni M, Brinkmann I, Kinzebach S, Grassl M, Weiss C, Bugert P, et al. A comparative analysis of the adipogenic potential in human mesenchymal stromal cells from cord blood and other sources. Cytotherapy. (2013) 15:7688.e2. doi: 10.1016/j.jcyt.2012.11.001

259. Chang Y, Shih DT, Tseng C, Hsieh T, Lee D, Hwang S. Disparate mesenchyme-lineage tendencies in mesenchymal stem cells from human bone marrow and umbilical cord blood. Stem Cells. (2006) 24:679-85. doi: 10.1634/stemcells.2004-0308

260. Brennan MÁ, Barilani M, Rusconi F, Lima J de, Vidal L, Lavazza $\mathrm{C}$, et al. Chondrogenic and BMP-4 primings confer osteogenesis potential to human cord blood mesenchymal stromal cells delivered with biphasic calcium phosphate ceramics. Sci Rep. (2021) 11:6751. doi: 10.1038/s41598-021-86147-9

261. Vizoso FJ, Eiro N, Cid S, Schneider J, Perez-Fernandez R. Mesenchymal stem cell secretome: toward cell-free therapeutic strategies in regenerative medicine. Int J Mol Sci. (2017) 18:1852. doi: 10.3390/ijms18091852

262. Zha K, Li X, Yang Z, Tian G, Sun Z, Sui X, et al. Heterogeneity of mesenchymal stem cells in cartilage regeneration: from characterization to application. Npj Regen Med. (2021) 6:14. doi: 10.1038/s41536-021-00122-6

263. Ham O, Lee CY, Kim R, Lee J, Oh S, Lee MY, et al. Therapeutic potential of differentiated mesenchymal stem cells for treatment of osteoarthritis. Int $J$ Mol Sci. (2015) 16:14961-78. doi: 10.3390/ijms160714961

264. Donders R, Bogie JFJ, Ravanidis S, Gervois P, Vanheusden M, Marée $\mathrm{R}$, et al. Human Wharton's jelly-derived stem cells display a distinct immunomodulatory and proregenerative transcriptional signature compared to bone marrow-derived stem cells. Stem Cells Dev. (2018) 27:65-84. doi: 10.1089/scd.2017.0029

265. Bianco P, Cao X, Frenette PS, Mao JJ, Robey PG, Simmons PJ, et al. The meaning, the sense and the significance: translating the science of mesenchymal stem cells into medicine. Nat Med. (2013) 19:35-42. doi: $10.1038 / \mathrm{nm} .3028$

266. Wright A, Arthaud-Day ML, Weiss ML. Therapeutic use of mesenchymal stromal cells: the need for inclusive characterization guidelines to accommodate all tissue sources and species. Front Cell Dev Biol. (2021) 9:632717. doi: 10.3389/fcell.2021.632717

267. Lee NE, Kim SJ, Yang S-J, Joo S-Y, Park H, Lee KW, et al. Comparative characterization of mesenchymal stromal cells from multiple abdominal adipose tissues and enrichment of angiogenic ability via CD146 molecule. Cytotherapy. (2017) 19:170-80. doi: 10.1016/j.jcyt.2016.11.002

268. Witkowski M, Landmesser U, Rauch U. Tissue factor as a link between inflammation and coagulation. Trends Cardiovas Med. (2016) 26:297-303. doi: 10.1016/j.tcm.2015.12.001

269. George MJ, Prabhakara K, Toledano-Furman NE, Wang Y, Gill BS, Wade CE, et al. Clinical cellular therapeutics accelerate clot formation. Stem Cell Transl Med. (2018) 7:731-9. doi: 10.1002/sctm.18-0015

270. Shiratsuki S, Terai S, Murata Y, Takami T, Yamamoto N, Fujisawa K, et al. Enhanced survival of mice infused with bone marrow-derived as compared with adipose-derived mesenchymal stem cells. Hepatol Res. (2015) 45:13539. doi: 10.1111/hepr.12507

271. Busser H, Najar M, Raicevic G, Pieters K, Pombo RV, Philippart P, et al. Isolation and characterization of human mesenchymal stromal cell subpopulations: comparison of bone marrow and adipose tissue. Stem Cells Dev. (2015) 24:2142-57. doi: 10.1089/scd.2015.0172

272. Holley RJ, Tai G, Williamson AJK, Taylor S, Cain SA, Richardson $\mathrm{SM}$, et al. Comparative quantification of the surfaceome of human multipotent mesenchymal progenitor cells. Stem Cell Rep. (2015) 4:473-88. doi: $10.1016 /$ j.stemcr.2015.01.007

273. Álvarez-Viejo M, Menéndez-Menéndez Y, Otero-Hernández J. CD271 as a marker to identify mesenchymal stem cells from diverse sources before culture. World J Stem Cells. (2015) 7:470. doi: 10.4252/wjsc.v7.i2.470

274. Murphy MB, Moncivais K, Caplan AI. Mesenchymal stem cells: environmentally responsive therapeutics for regenerative medicine. Exp Mol Medicine. (2013) 45:e54-e54. doi: 10.1038/emm.2013.94

275. Burja B, Barlič A, Erman A, Mrak-Poljšak K, Tomšič M, Sodin-Semrl S, et al. Human mesenchymal stromal cells from different tissues exhibit unique responses to different inflammatory stimuli. Curr Res Transl Med. (2020) 68:217-24. doi: 10.1016/j.retram.2020.05.006

276. Rezaie J, Mehranjani MS, Rahbarghazi R, Shariatzadeh MA. Angiogenic and restorative abilities of human mesenchymal stem cells were reduced following treatment with serum from diabetes mellitus type 2 patients. J Cell Biochem. (2018) 119:524-35. doi: 10.1002/jcb.26211

277. Tsuji K, Kitamura S, Wada J. Secretomes from mesenchymal stem cells against acute kidney injury: possible heterogeneity. Stem Cells Int. (2018) 2018:1-14. doi: 10.1155/2018/8693137

278. Liu Y, Holmes C. Tissue regeneration capacity of extracellular vesicles isolated from bone marrow-derived and adipose-derived mesenchymal stromal/stem cells. Front Cell Dev Biol. (2021) 9:648098. doi: $10.3389 /$ fcell.2021.648098 
279. Shin S, Lee J, Kwon Y, Park K-S, Jeong J-H, Choi S-J, et al. Comparative proteomic analysis of the mesenchymal stem cells secretome from adipose, bone marrow, placenta and Wharton's Jelly. Int J Mol Sci. (2021) 22:845. doi: 10.3390/ijms22020845

280. González PL, Carvajal C, Cuenca J, Alcayaga-Miranda F, Figueroa FE, Bartolucci J, et al. Chorion mesenchymal stem cells show superior differentiation, immunosuppressive, and angiogenic potentials in comparison with haploidentical maternal placental cells. Stem Cell Transl Med. (2015) 4:1109-21. doi: 10.5966/sctm.2015-0022

281. Lu H, Wang F, Mei H, Wang S, Cheng L. Human adipose mesenchymal stem cells show more efficient angiogenesis promotion on endothelial colonyforming cells than umbilical cord and endometrium. Stem Cells Int. (2018) 2018:7537589. doi: 10.1155/2018/7537589

282. Hsiao ST-F, Asgari A, Lokmic Z, Sinclair R, Dusting GJ, Lim SY, et al. Comparative analysis of paracrine factor expression in human adult mesenchymal stem cells derived from bone marrow, adipose, and dermal tissue. Stem Cells Dev. (2012) 21:2189-203. doi: 10.1089/scd.2011.0674

283. Du WJ, Chi Y, Yang ZX, Li ZJ, Cui JJ, Song BQ, et al. Heterogeneity of proangiogenic features in mesenchymal stem cells derived from bone marrow, adipose tissue, umbilical cord, and placenta. Stem Cell Res Ther. (2016) 7:163. doi: 10.1186/s13287-016-0418-9

284. Liu J, Hao H, Xia L, Ti D, Huang H, Dong L, et al. Hypoxia pretreatment of bone marrow mesenchymal stem cells facilitates angiogenesis by improving the function of endothelial cells in diabetic rats with lower ischemia. PLoS ONE. (2015) 10:e0126715. doi: 10.1371/journal.pone.0126715

285. Liu J, Hao H, Huang H, Tong C, Ti D, Dong L, et al. Hypoxia regulates the therapeutic potential of mesenchymal stem cells through enhanced autophagy. Int J Low Extremity Wounds. (2015) 14:63-72. doi: 10.1177/1534734615573660

286. Du W, Li X, Chi Y, Ma F, Li Z, Yang S, et al. VCAM-1+ placenta chorionic villi-derived mesenchymal stem cells display potent pro-angiogenic activity. Stem Cell Res Ther. (2016) 7:49. doi: 10.1186/s13287-016-0297-0

287. Kachgal S, Putnam AJ. Mesenchymal stem cells from adipose and bone marrow promote angiogenesis via distinct cytokine and protease expression mechanisms. Angiogenesis. (2010) 14:47-59. doi: 10.1007/s10456-010-9194-9

288. Niel G van, D'Angelo G, Raposo G. Shedding light on the cell biology of extracellular vesicles. Nat Rev Mol Cell Bio. (2018) 19:213-28. doi: $10.1038 / \mathrm{nrm} .2017 .125$

289. Mendt M, Rezvani K, Shpall E. Mesenchymal stem cell-derived exosomes for clinical use. Bone Marrow Transpl. (2019) 54:789-92. doi: 10.1038/s41409-019-0616-Z

290. Keshtkar S, Azarpira N, Ghahremani MH. Mesenchymal stem cell-derived extracellular vesicles: novel frontiers in regenerative medicine. Stem Cell Res Ther. (2018) 9:63. doi: 10.1186/s13287-018-0791-7

291. Börger V, Bremer M, Ferrer-Tur R, Gockeln L, Stambouli O, Becic A, et al. Mesenchymal stem/stromal cell-derived extracellular vesicles and their potential as novel immunomodulatory therapeutic agents. Int J Mol Sci. (2017) 18:1450. doi: 10.3390/ijms18071450

292. Wang K, Jiang Z, Webster KA, Chen J, Hu H, Zhou Y, et al. Enhanced cardioprotection by human endometrium mesenchymal stem cells driven by exosomal MicroRNA-21. Stem Cell Transl Med. (2017) 6:209-22. doi: 10.5966/sctm.2015-0386

293. Pomatto M, Gai C, Negro F, Cedrino M, Grange C, Ceccotti E, et al. Differential therapeutic effect of extracellular vesicles derived by bone marrow and adipose mesenchymal stem cells on wound healing of diabetic ulcers and correlation to their cargoes. Int J Mol Sci. (2021) 22:3851. doi: 10.3390/ijms22083851

294. Liang X, Zhang L, Wang S, Han Q, Zhao RC. Exosomes secreted by mesenchymal stem cells promote endothelial cell angiogenesis by transferring miR-125a. J Cell Sci. (2016) 129:2182-9. doi: 10.1242/jcs.170373

295. Xue C, Shen Y, Li X, Li B, Zhao S, Gu J, et al. Exosomes derived from hypoxiatreated human adipose mesenchymal stem cells enhance angiogenesis through the PKA signaling pathway. Stem Cells Dev. (2018) 27:456-65. doi: $10.1089 / \mathrm{scd} .2017 .0296$

296. Tracy SA, Ahmed A, Tigges JC, Ericsson M, Pal AK, Zurakowski D, et al. A comparison of clinically relevant sources of mesenchymal stem cell-derived exosomes: bone marrow and amniotic fluid. J Pediatr Surg. (2018) 54:86-90. doi: 10.1016/j.jpedsurg.2018.10.020
297. Anderson JD, Johansson HJ, Graham CS, Vesterlund M, Pham MT, Bramlett CS, et al. Comprehensive proteomic analysis of mesenchymal stem cell exosomes reveals modulation of angiogenesis via nuclear factor-KappaB signaling. Stem Cells. (2016) 34:601-13. doi: 10.1002/ste m.2298

298. Teng X, Chen L, Chen W, Yang J, Yang Z, Shen Z. Mesenchymal stem cellderived exosomes improve the microenvironment of infarcted myocardium contributing to angiogenesis and anti-inflammation. Cell Physiol Biochem. (2015) 37:2415-24. doi: 10.1159/000438594

299. Shabbir A, Cox A, Rodriguez-Menocal L, Salgado M, Badiavas EV. Mesenchymal stem cell exosomes induce proliferation and migration of normal and chronic wound fibroblasts, and enhance angiogenesis in vitro. Stem Cells Dev. (2015) 24:1635-47. doi: 10.1089/scd.201 4.0316

300. Zhang J, Guan J, Niu X, Hu G, Guo S, Li Q, et al. Exosomes released from human induced pluripotent stem cells-derived MSCs facilitate cutaneous wound healing by promoting collagen synthesis and angiogenesis. J Transl Med. (2015) 13:49. doi: 10.1186/s12967-015-0417-0

301. Ferguson SW, Wang J, Lee CJ, Liu M, Neelamegham S, Canty JM, et al. The microRNA regulatory landscape of MSC-derived exosomes: a systems view. Sci Rep. (2018) 8:1419. doi: 10.1038/s41598-018-19581-x

302. Reis M, Mavin E, Nicholson L, Green K, Dickinson AM, Wang X. Mesenchymal stromal cell-derived extracellular vesicles attenuate dendritic cell maturation and function. Front Immunol. (2018) 9:2538. doi: 10.3389/fimmu.2018.02538

303. Fang S, Xu C, Zhang Y, Xue C, Yang C, Bi H, et al. Umbilical cordderived mesenchymal stem cell-derived exosomal MicroRNAs suppress myofibroblast differentiation by inhibiting the transforming growth factor$\beta /$ SMAD2 pathway during wound healing. Stem Cell Transl Med. (2016) 5:1425-39. doi: 10.5966/sctm.2015-0367

304. Qiu G, Zheng G, Ge M, Wang J, Huang R, Shu Q, et al. Mesenchymal stem cell-derived extracellular vesicles affect disease outcomes via transfer of microRNAs. Stem Cell Res Ther. (2018) 9:320. doi: 10.1186/s13287-018-1069-9

305. Baglio SR, Rooijers K, Koppers-Lalic D, Verweij FJ, Lanzón MP, Zini N, et al. Human bone marrow- and adipose-mesenchymal stem cells secrete exosomes enriched in distinctive miRNA and tRNA species. Stem Cell Res Ther. (2015) 6:127. doi: 10.1186/s13287-015-0116-Z

306. Whittaker TE, Nagelkerke A, Nele V, Kauscher U, Stevens MM. Experimental artefacts can lead to misattribution of bioactivity from soluble mesenchymal stem cell paracrine factors to extracellular vesicles. J Extracell Vesicles. (2020) 9:1807674. doi: 10.1080/20013078.2020.1807674

307. Blanc KL, Davies LC. Mesenchymal stromal cells and the innate immune response. Immunol Lett. (2015) 168:140-6. doi: 10.1016/j.imlet.2015.05.004

308. Wang S, Zhu R, Li H, Li J, Han Q, Zhao RC. Mesenchymal stem cells and immune disorders: from basic science to clinical transition. Front Med. (2019) 13:138-51. doi: 10.1007/s11684-018-0627-y

309. Wang Y, Chen X, Cao W, Shi Y. Plasticity of mesenchymal stem cells in immunomodulation: pathological and therapeutic implications. Nat Immunol. (2014) 15:1009-16. doi: 10.1038/ni.3002

310. Kronsteiner B, Wolbank S, Peterbauer A, Hackl C, Redl H, Griensven M van, et al. Human mesenchymal stem cells from adipose tissue and amnion influence T-cells depending on stimulation method and presence of other immune cells. Stem Cells Dev. (2011) 20:2115-26. doi: 10.1089/scd.201 1.0031

311. Bárcia RN, Santos JM, Filipe M, Teixeira M, Martins JP, Almeida J, et al. What makes umbilical cord tissue-derived mesenchymal stromal cells superior immunomodulators when compared to bone marrow derived mesenchymal stromal cells? Stem Cells Int. (2015) 2015:1-14. doi: 10.1155/2015/583984

312. Ménard C, Dulong J, Roulois D, Hébraud B, Verdière L, Pangault C, et al. Integrated transcriptomic, phenotypic, and functional study reveals tissue-specific immune properties of mesenchymal stromal cells: MSC properties rely on their tissue of origin. Stem Cells. (2019) 38:146-59. doi: 10.1002/stem.3077

313. Paladino FV, Rodrigues $\mathrm{J}$ de $\mathrm{M}$, Silva A da, Goldberg AC. The immunomodulatory potential of Wharton's Jelly Mesenchymal Stem/Stromal Cells. Stem Cells Int. (2019) 2019:1-7. doi: $10.1155 / 2019 / 3548917$ 
314. Tago Y, Kobayashi C, Ogura M, Wada J, Yamaguchi S, Yamaguchi T, et al. Human amnion-derived mesenchymal stem cells attenuate xenogeneic graftversus-host disease by preventing T cell activation and proliferation. Sci Rep. (2021) 11:2406. doi: 10.1038/s41598-021-81916-y

315. Li M, Soder R, Abhyankar S, Abdelhakim H, Braun MW, Trinidad $\mathrm{CV}$, et al. WJMSC-derived small extracellular vesicle enhance $\mathrm{T}$ cell suppression through PD-L1. J Extracell Vesicles. (2021) 10:e12067. doi: $10.1002 /$ jev2.12067

316. Mattar P, Bieback K. Comparing the immunomodulatory properties of bone marrow, adipose tissue, and birth-associated tissue mesenchymal stromal cells. Front Immunol. (2015) 6:560. doi: 10.3389/fimmu.2015.00560

317. Iglesias-Lopez C, Obach M, Vallano A, Agustí A. Comparison of regulatory pathways for the approval of advanced therapies in the European Union and the United States. Cytotherapy. (2021) 23:261-74. doi: 10.1016/j.jcyt.2020.11.008

318. Sakai D, Schol J, Foldager CB, Sato M, Watanabe M. Regenerative technologies to bed side: evolving the regulatory framework. J Orthop Transl. (2017) 9:1-7. doi: 10.1016/j.jot.2017.02.001

319. Iglesias-López C, Agustí A, Obach M, Vallano A. Regulatory framework for advanced therapy medicinal products in Europe and United States. Front Pharmacol. (2019) 10:921. doi: 10.3389/fphar.2019. 00921

320. Jayaraman $\mathrm{P}$, Lim $\mathrm{R}, \mathrm{Ng}$ J, Vemuri MC. Acceleration of translational mesenchymal stromal cell therapy through consistent quality GMP manufacturing. Front Cell Dev Biol. (2021) 9:648472. doi: $10.3389 /$ fcell.2021.648472

321. James D. How short-term gain can lead to long-term pain. Cell Gene Ther Insights. (2017) 3:18. doi: 10.18609/cgti.2017.018

322. Sensebé L, Bourin P, Tarte K. Good manufacturing practices production of mesenchymal stem/stromal cells. Hum Gene Therap. (2011) 22:19-26. doi: 10.1089/hum.2010.197

323. Mastrolia I, Foppiani EM, Murgia A, Candini O, Samarelli AV, Grisendi G, et al. Challenges in clinical development of mesenchymal stromal/stem cells: concise review. Stem Cells Transl Med. (2019) 8:1135-48. doi: 10.1002/sctm.19-0044

324. Sciezyńska A, Soszyńska M, Szpak P, Krześniak N, Malejczyk J, Kalaszczyńska I. Influence of hypothermic storage fluids on mesenchymal stem cell stability: a comprehensive review and personal experience. Cells. (2021) 10:1043. doi: $10.3390 /$ cells 10051043

325. Stolzing A, Jones E, McGonagle D, Scutt A. Age-related changes in human bone marrow-derived mesenchymal stem cells: consequences for cell therapies. Mechan Ageing Dev. (2008) 129:163-73. doi: 10.1016/j.mad.2007.12.002

326. Payne KA, Didiano DM, Chu CR. Donor sex and age influence the chondrogenic potential of human femoral bone marrow stem cells. Osteoarthritis and cartilage OARS. Osteoarthritis Res Society. (2010) 18:70513. doi: 10.1016/j.joca.2010.01.011

327. Sammour I, Somashekar S, Huang J, Batlahally S, Breton M, Valasaki K, et al. The Effect of Gender on Mesenchymal Stem Cell (MSC) efficacy in neonatal hyperoxia-induced lung injury. PLOS ONE. (2016) 11:e0164269. doi: 10.1371/journal.pone.0164269

328. Tajiri N, Duncan K, Borlongan M, Pabon M, Acosta S, Pena I de la, et al. Adult stem cell transplantation: is gender a factor in stemness? Int J Mol Sci. (2014) 15:15225-43. doi: 10.3390/ijms150915225

329. Bernardo ME, Locatelli F, Fibbe WE. Mesenchymal stromal cells. Ann Ny Acad Sci. (2009) 1176:101-7. doi: 10.1111/j.1749-6632.2009.04607.x

330. Fraser JK, Wulur I, Alfonso Z, Hedrick MH. Fat tissue: an underappreciated source of stem cells for biotechnology. Trends Biotechnol. (2006) 24:150-4. doi: 10.1016/j.tibtech.2006.01.010

331. Griffin MD, Ryan AE, Alagesan S, Lohan P, Treacy O, Ritter T. Antidonor immune responses elicited by allogeneic mesenchymal stem cells: what have we learned so far? Immunol Cell Biol. (2013) 91:40-51. doi: $10.1038 /$ icb. 2012.67

332. Kim DS, Lee MW, Lee T-H, Sung KW, Koo HH, Yoo KH. Cell culture density affects the stemness gene expression of adipose tissue-derived mesenchymal stem cells. Biomed Rep. (2017) 6:300-6. doi: 10.3892/br.2017.845

333. Banfi A, Muraglia A, Dozin B, Mastrogiacomo M, Cancedda R, Quarto R. Proliferation kinetics and differentiation potential of ex vivo expanded human bone marrow stromal cells Implications for their use in cell therapy. Exp Hematol. (2000) 28:707-15. doi: 10.1016/s0301-472x(00)00160-0

334. Yang Y-HK, Ogando CR, See CW, Chang T-Y, Barabino GA. Changes in phenotype and differentiation potential of human mesenchymal stem cells aging in vitro. Stem Cell Res Ther. (2018) 9:131. doi: 10.1186/s13287-018-0876-3

335. LI X-Y, Ding J, Zheng Z-H, Li X-Y, Wu Z-B, Zhu P. Long-term culture in vitro impairs the immunosuppressive activity of mesenchymal stem cells on T cells. Mol Med Rep. (2012) 6:1183-9. doi: 10.3892/mmr.2012.1039

336. Wang Y, Zhang Z, Chi Y, Zhang Q, Xu F, Yang Z, et al. Long-term cultured mesenchymal stem cells frequently develop genomic mutations but do not undergo malignant transformation. Cell Death Dis. (2013) 4:e950. doi: $10.1038 /$ cddis. 2013.480

337. Zhao Q, Zhang L, Wei Y, Yu H, Zou L, Huo J, et al. Systematic comparison of hUC-MSCs at various passages reveals the variations of signatures and therapeutic effect on acute graft-versus-host disease. Stem Cell Res Ther. (2019) 10:354. doi: 10.1186/s13287-019-1478-4

338. Neuhuber B, Swanger SA, Howard L, Mackay A, Fischer I. Effects of plating density and culture time on bone marrow stromal cell characteristics. Exp Hematol. (2008) 36:1176-1185. doi: 10.1016/j.exphem.2008. 03.019

339. Bartmann C, Rohde E, Schallmoser K, Pürstner P, Lanzer G, Linkesch W, et al. Two steps to functional mesenchymal stromal cells for clinical application. Transfusion. (2007) 47:1426-35. doi: 10.1111/j.1537-2995.2007. 01219.x

340. Both SK, Muijsenberg AJC van der, Blitterswijk CA van, Boer J de, Bruijn JD de. A Rapid and efficient method for expansion of human mesenchymal stem cells. Tissue Eng. (2007) 13:3-9. doi: 10.1089/ten.2005.0513

341. Sotiropoulou PA, Perez SA, Salagianni M, Baxevanis CN, Papamichail M. Characterization of the optimal culture conditions for clinical scale production of human mesenchymal stem cells. Stem Cells. (2006) 24:462-71. doi: 10.1634/stemcells.2004-0331

342. Sekiya I, Larson BL, Smith JR, Pochampally R, Cui J, Prockop DJ. Expansion of human adult stem cells from bone marrow stroma: conditions that maximize the yields of early progenitors and evaluate their quality. Stem Cells. (2002) 20:530-41. doi: 10.1634/stemcells.20-6-530

343. Hoffmann A, Floerkemeier T, Melzer C, Hass R. Comparison of in vitrocultivation of human mesenchymal stroma/stem cells derived from bone marrow and umbilical cord. J Tissue Eng Regen M. (2017) 11:2565-81. doi: $10.1002 /$ term. 2153

344. Sensebé L, Bourin P, Douay L. Good Manufacturing Practices: Clinical-Scale Production of Mesenchymal Stem Cells. Wiley-VCH Verlag GmbH \& Co. KGaA. (2006) doi: 10.1002/3527608745.ch6

345. Bowles AC, Kouroupis D, Willman MA, Orfei CP, Agarwal A, Correa D. Signature quality attributes of CD146+ mesenchymal stem/stromal cells correlate with high therapeutic and secretory potency. Stem Cells. (2020) 38:1034-49. doi: 10.1002/stem.3196

346. Ilas DC, Baboolal TG, Churchman SM, Jones WG, Giannoudis PV, Bühring $\mathrm{H}-\mathrm{J}$, et al. The osteogenic commitment of CD271+CD56+ bone marrow stromal cells (BMSCs) in osteoarthritic femoral head bone. Sci Rep-uk. (2020) 10:11145. doi: 10.1038/s41598-020-67998-0

347. Cuthbert RJ, Giannoudis PV, Wang XN, Nicholson L, Pawson D, Lubenko A, et al. Examining the feasibility of clinical grade CD271+ enrichment of mesenchymal stromal cells for bone regeneration. PLoS ONE. (2015) 10:e0117855. doi: 10.1371/journal.pone.0117855

348. Psaltis PJ, Paton S, See F, Arthur A, Martin S, Itescu S, et al. Enrichment for STRO-1 expression enhances the cardiovascular paracrine activity of human bone marrow-derived mesenchymal cell populations. J Cell Physiol. (2010) 223:530-40. doi: 10.1002/jcp.22081

349. Masterson C, Devaney J, Horie S, O’Flynn L, Deedigan L, Elliman S, et al. Syndecan-2-positive, bone marrow-derived human mesenchymal stromal cells attenuate bacterial-induced acute lung injury and enhance resolution of ventilator-induced lung injury in rats. Anesthesiology. (2018) 129:502-16. doi: 10.1097/aln.0000000000002327

350. Bahr L von, Sundberg B, Lönnies L, Sander B, Karbach H, Hägglund H, et al. Long-term complications, immunologic effects, and role of passage for outcome in mesenchymal stromal cell therapy. Biol Blood Marrow Treat. (2012) 18:557-64. doi: 10.1016/j.bbmt.2011.07.023 
351. Mochizuki T, Muneta T, Sakaguchi Y, Nimura A, Yokoyama A, Koga H, et al. Higher chondrogenic potential of fibrous synovium- and adipose synovium-derived cells compared with subcutaneous fat-derived cells: Distinguishing properties of mesenchymal stem cells in humans. Arthritis Rheum. (2006) 54:843-53. doi: 10.1002/art.21651

352. Riis S, Nielsen FM, Pennisi CP, Zachar V, Fink T. Comparative analysis of media and supplements on initiation and expansion of adipose-derived stem cells. Stem Cell Transl Med. (2016) 5:314-24. doi: 10.5966/sctm.2015-0148

353. Tsutsumi S, Shimazu A, Miyazaki K, Pan H, Koike C, Yoshida E, et al. Retention of multilineage differentiation potential of mesenchymal cells during proliferation in response to FGF. Biochem Bioph Res Co. (2001) 288:413-9. doi: 10.1006/bbrc.2001.5777

354. Solchaga LA, Penick K, Porter JD, Goldberg VM, Caplan AI, Welter JF. FGF2 enhances the mitotic and chondrogenic potentials of human adult bone marrow-derived mesenchymal stem cells. J Cell Physiol. (2005) 203:398-409. doi: $10.1002 /$ jcp. 20238

355. Tekkatte C, Gunasingh GP, Cherian KM, Sankaranarayanan K. "Humanized" stem cell culture techniques: the animal serum controversy. Stem Cells Int. (2011) 2011:504723. doi: 10.4061/2011/504723

356. Burnouf T, Strunk D, Koh MBC, Schallmoser K. Human Platelet Lysate: Replacing Fetal Bovine Serum as a Gold Standard for Human Cell Propagation? (2016). Available online at: https://www.sciencedirect.com/ science/article/abs/pii/S0142961215008753?via\%3Dihub

357. Schallmoser K, Henschler R, Gabriel C, Koh MBC, Burnouf T. Production and quality requirements of human platelet lysate: a position statement from the working party on cellular therapies of the international society of blood transfusion. Trends Biotechnol. (2020) 38:13-23. doi: 10.1016/j.tibtech.2019.06.002

358. Stühler A, Blümel J. Specific aspects for virus safety of raw materials for cellular-based medicinal products. Bundesgesundheitsbl. (2015) 58:1233-8. doi: 10.1007/s00103-015-2238-y

359. Wu X, Kang H, Liu X, Gao J, Zhao K, Ma Z. Serum and xeno-free, chemically defined, no-plate-coating-based culture system for mesenchymal stromal cells from the umbilical cord. Cell Proliferat. (2016) 49:579-88. doi: 10.1111/cpr.12279

360. Patrikoski M, Juntunen M, Boucher S, Campbell A, Vemuri MC, Mannerström B, et al. Development of fully defined xeno-free culture system for the preparation and propagation of cell therapy-compliant human adipose stem cells. Stem Cell Res Therap. (2013) 4:1-5. doi: 10.1186/scrt175

361. Bhat S, Viswanathan P, Chandanala S, Prasanna SJ, Seetharam RN. Expansion and characterization of bone marrow derived human mesenchymal stromal cells in serum-free conditions. Sci Rep. (2021) 11:3403. doi: 10.1038/s41598-021-83088-1

362. Nikolits I, Nebel S, Egger D, Kreß S, Kasper C. Towards physiologic culture approaches to improve standard cultivation of mesenchymal stem cells. Cells. (2021) 10:886. doi: 10.3390/cells10040886

363. Gottipamula S, Muttigi MS, Chaansa S, Ashwin KM, Priya N, Kolkundkar $\mathrm{U}$, et al. Large-scale expansion of pre-isolated bone marrow mesenchymal stromal cells in serum-free conditions. J Tissue Eng Regen M. (2013) 10:10819. doi: $10.1002 /$ term.1713
364. Mizukami A, Chilima TDP, Orellana MD, Neto MA, Covas DT, Farid SS, et al. Technologies for large-scale umbilical cord-derived MSC expansion: experimental performance and cost of goods analysis. Biochem Eng J. (2018) 135:36-48. doi: 10.1016/j.bej.2018.02.018

365. Koh B, Sulaiman N, Fauzi MB, Law JX, Ng MH, Idrus RBH, et al. Three dimensional microcarrier system in mesenchymal stem cell culture: a systematic review. Cell Biosci. (2020) 10:75. doi: 10.1186/s13578-020-00438-8

366. Schirmaier C, Jossen V, Kaiser SC, Jüngerkes F, Brill S, Safavi-Nab A, et al. Scale-up of adipose tissue-derived mesenchymal stem cell production in stirred single-use bioreactors under low-serum conditions. Eng Life Sci. (2017) 14:292-303. doi: 10.1002/elsc.201300134

367. Timmins NE, Kiel M, Günther M, Heazlewood C, Doran MR, Brooke $\mathrm{G}$, et al. Closed system isolation and scalable expansion of human placental mesenchymal stem cells. Biotechnol Bioeng. (2012) 109:1817-26. doi: 10.1002/bit.24425

368. Mizukami A, Orellana MD, Caruso SR, Prata KL, Covas DT, Swiech K. Efficient expansion of mesenchymal stromal cells in a disposable fixed bed culture system. Biotechnol Progr. (2013) 29:568-72. doi: 10.1002/btpr.1707

369. Hanley PJ, Mei Z, Durett AG, Cabreira-Harrison M da G, Klis M, Li W, et al. Efficient manufacturing of therapeutic mesenchymal stromal cells using the quantum cell expansion system. Cytotherapy. (2014) 16:1048-58. doi: 10.1016/j.jcyt.2014.01.417

370. Lechanteur C. Large-scale clinical expansion of mesenchymal stem cells in the gmp-compliant, closed automated quantum $(\mathbb{Q}$ cell expansion system: comparison with expansion in traditional T-flasks. J Stem Cell Res Therap. (2014) 4:222. doi: 10.4172/2157-7633.1000222

371. Stephenson M, Grayson W. Recent advances in bioreactors for cell-based therapies. F1000Research. (2018) 7:1. doi: 10.12688/f1000research.12533.1

Conflict of Interest: TO'B is a founder, director and equity holder in Orbsen Therapeutics Ltd.

The remaining authors declare that the research was conducted in the absence of any commercial or financial relationships that could be construed as a potential conflict of interest.

Publisher's Note: All claims expressed in this article are solely those of the authors and do not necessarily represent those of their affiliated organizations, or those of the publisher, the editors and the reviewers. Any product that may be evaluated in this article, or claim that may be made by its manufacturer, is not guaranteed or endorsed by the publisher.

Copyright (c) 2021 Calcat-i-Cervera, Sanz-Nogués and O'Brien. This is an openaccess article distributed under the terms of the Creative Commons Attribution License (CC BY). The use, distribution or reproduction in other forums is permitted, provided the original author(s) and the copyright owner(s) are credited and that the original publication in this journal is cited, in accordance with accepted academic practice. No use, distribution or reproduction is permitted which does not comply with these terms. 